



\section{BOTANICAL GRAMMAR}

\section{AND}

\section{DICTIONARY ;}

TRANSLATED

FROM THE FRENCH,

. OF

BUIIIABD AND RICIAARD.

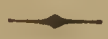

BY PROF. A. EATON.

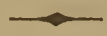

\section{Thind Ebition,}

Wholly written over, and now including the Natural Ordets of

Linneus and Jessieu.

\section{ALBANY :}

PRINTED BY WEBSTERS AND SKINNERS,

At their Bookstore, at the Elm Tree, in State-Street, corner of P'earl-Sireet.

1828. 


\section{ANNEx \\ MORTHER.V DISTRICT OF NEW-YORK, s.}

BE IT REMEMBERFD, That on the eighth day of September, is the fifty-second year of the Independencc of the United States of Ainerica, WEDSTERS and SKINNERs, of the said district, have deposited in this oflice, the title of a book, the right whereof they claim as proprietors, in the words fullow. ing, to wit:

"BOTANICAL GRAMMAR AND DICTIONARY, TRANSLATED FROM " THR Frexch of BULLIARD and RICHARD. By Prof. A. EdTON.

"Thirn Enition, wholly written over, and now including the Natural Ol"ders of Linneus and Jessieu."

In conformity to the act of the Congress of thc United States, entitled "an act for the encouragcment of learning, by securing the copies of inaps, charta, and books, to the authors and proprietors of such copies, during the times there. in mentioned," and also to an act entitled "an act supplementary to an act entitled an act for the encouragement of learning, by securing the copies of maps, charts, and books, to the authors and proprietors of such copies, during the times therein Inentioned, and extending the benefits to the arts of desiguing, engraving, and etcling historical and other prints."

RICHARD B. LANSING,

Clerk of the N. District of New-York.

\section{ADVERTISEMENT.}

This Grammar and Dictionary were prepared for the fifth edition of the Manual of Botany. A few hundred extra copies are printed to accommodate the purchasers of former editions, and those who use the works of Muhlenberg, Pursh, Nuttall, Bigelow, Torry, Elliott, Barton, Darlington, Oaks, and others.

\section{RENSSELAER SCHOOL,}

A. E.

Ang. 29, 1828. 


\section{Grammar and Dictionary of Botany.}

\section{GRAMMAR OF BOTANY.}

IT is not necessary that a student in Botany should romember the definitions of all the terms used in the descriptions of plants. 'There are some terms, however, which ought to be studied in systematic order. Such terms, so systematized, may constitute a grammar of botany, or a botanical nomenclature.

The annexed grammar of botany comprizes the most important elementary terms; and all that a student should store up' in lis memory.

\section{Elementary Organs.}

Fvery plant is either plienoyamons or cryptogamous.

P'henoganous plants have their stamens and pistils sufficiently mani1 for examination. yptogamous plants eithei lose the staminate organs before they rne manifest, or they are too minute for inspection.

1. . Classes, Orders and Genera of the Linnean system, are foundreslly on the seven elementary organs of fructification.

These are,

vlyx. The outer or lower part of the flower, genera!ly not coLured.*

2. Corol. The coloured blossom, within or above the calys.

3. Stamens. The organs immediately surrounding or adjoining the central one ; consisting of mealy or glutinuus kuobs, either sessile or supported on filaments.

4. Pistil. The central organ of the flower, whose base becomes the pericarp and seed.

5. Pericarp. The covering of the seed, whether pod, shell, bag, or pulpy substance.

6. Seed. The essential part, which contains the rudiment of a new plant.

7. Receplacle. The base which sustains the other six parts, being at the eud of the flower-stem.

\section{Subdivisions of the Calyx.}

Every caly $\mathrm{x}$ is either monophyllous, consisting of one leaf; or polyphyllous, consisting of more than one leaf. Either kind may be:

1. Perianth. That calyx which adjoins and surrousds the other parts of the flower, as of the apple, rose, sc.

About two thirds of all plants have perianths.

* In the language of Botany, any part of a plant is not coloured when it iz rreen; as the calyx of the apple is said not to be coloured, because it is green ; and that of the nasturtion is coloured, because it is not green. 
․ Involucre. That calyx which comes out at some distance below the flower, and never encloses it. It is commonly at the origin of the peduncles of umbels, and sometines attached tu other aggregate flowers.

Involucres are either universal, placed at the origin of the universal $n$ ubel, as in caraway, lovage, \&c.; or partial, placed at the origin of it particular umbel, as in coriander; or proper, placed beneath a singlc Hower.

3. Spathe. A kind of membrane, which at first encloses the flower, and after it expands, is left at a distance below it, as daffodil, onion, Indian turnip.

1. Glume. That kind of calyx whicl is composed of one, two, or three valves or scales, commonly transparent at the margin, and often terminated by a long awn or beard. All grasses lave glume caly xes.

5. Antent. An assemblage of flower-bearing scales, arranged on a slender thread, or long receptacle; each scale generally constituting the lateral calyx of a flower, as in the willow, chesnut, pine, \&c.

6. Calyptre. The cap or hood of pistillate mosses, resembling in form and position an extinguisher set on a candle. Conspicuous in the common hair-cap moss.

7. Tolva. The ring or wrapper at first enclosing the pileus or head of a fungus; and which, after the plant has arrived to maturity contracts and remains on the stem or at the root.

\section{SuRdivisions of the Coror.}

Fivery corol is either monopetalous, consisting of one petal or er-leaf; or polypetalous, consisting of morc than onc.

*Monopelalous Corols are,

1. Bell-form. Hollowed out within the base, and generally diverging upwards, as Cantcrbury bells, gentian, \&xc.

2. Funnel-form. With a tubular base, and the border opening gradually in the form of a tunnel, as the thorn-apple, morning-glory.

3. Salver-form. Having a flat spreading limb or border, proceeding from the top of a tube, as lilac, trailing arbutus, \&c.

* It is proper to inform the student, in this place, of two important facts, counected with the descriptions of plants, which are made by references to naiural and artificial forms.

1. A certain number of forms were assumed by Linneus as standards for;'references; none of which are to be considered as perfect. But when any one of these forms is referred to, it is to be understood, that it is nearer the true form of the organ under consideration, than any other of these standard forms.

2. All standard forins are either drawn from well-known natural bodies, or from artificial bodies or implements known to the ancients. Some of the most cominon NaTural bodies are the egg, lips of animals, the throat, head, knee, the heart, the kidneys, the hand, bird's feet, spur, feather, a bay, a tooth, hair. bristles, silk, down, eye-lashes, veins, nerves, wings, ears, claws, \&c. Somc of the most common ArTizicial bodies or implements are, a spike, spindle, circle, oval, lance, line, awl, arrow, halbert, viol, lyre, saw, shield, cross, sa bre, needle, bell, keel, club, cone, leather, cup, greok letter delta, fork, urı, wheel, \&x. 
4. Wheel-form. Having a spreading border without a tube, or with an exeediug short one, as borage, laurel, mullein.

5. Labiate. A labiate corol is divided into two general parts, some. what resembling the lips of a horse or other animal. Labiate co. rols are either personate, (with the throat muffied) as snap-dragon; or ringene, (with the throat open) as mint, mother-wort, catnip, unonkey-llower.

\section{Polypetalous Corols are,}

1. Cruciform. Consisting of four equal petals spreading out in the form of a cross, as radish, cabbage, mustard, \&c.

*. Caryophylleous. Having fre single petals, each terminating in a long claw, enclosed in a tubular calyx, as pink, catch-fiy, cockle, Sec.

3. Liliaceous. A corol with six petals, spreading gradually from the base, so as altogether to exhibit a bell-form appearance, as tulip lily, \&c.

4. Rosaceous. A corol formed of roundish spreading petals withnut claws, or with extremely short ones, as rose, apple, strawberry, \&c.

5. Papilionaceous. A flower which consists of a banner, two wings and a keel, as pea, clover, \&zc. supposed to rssemble a butterfly.

If a corol agrees with none of the above descriptions, it is calied anomalous.

\section{SUdDivisior of the StaMeN.}

1. Anther. The knob of the stamen, which contains the polten : rery conspicuous in the lily, \&c. Never wanting.

2. Pollen. The dusty, mealy or glutinous subtance contained in the anthers. Never wanting.

3. Filament. That part of the stamen which connects the anther willz the receptacle, calyx or pistil. Often wanting; generally threadform when present.

\section{Sugditision of the Pistil.}

1. Stigma. The organ which terminates the pistil; very conspicuous in the lily, and hardly distinguishable in the Indian corn. Never wanting.

2. Germ. That part of the pistil which in matarity becomes the pericarp and the seed, as in the cherry, pompion. Never wanting.

3. Style. That part of the pistil which connects the stigma and the germ; very conspicuous in the lily; wanting in the tulip.

\section{Subdivision of the Pericarp.}

1. Silique. That kind of pod which has a longitudinal partition, with the seeds attached alternately to its opposite edges, as radish, cabbage, \&c.

2. Legume. A pod without a longitudinal partition, with the seeds attached to one suture only, as the pea, \&c.

3. Capsule. That kind of pericarp which opens by valves or pores, and becomes dry when ripe, as the poppy, which opens by nores. and the mullein by valves. 
4. Drupe. That kind of pericarp which consists of a thick tleshy o: cartilaginous coat enclosing a nut or stone, as in the cherry, in which it is said to be berry-like; and in the walnut, where it is dry.

5. Pome. A pulpy pericarp without valves, which contains within it a capsule, as apples, quiuces, \&c.

6. Berry. A pulpy pericarp enclosing seeds without any capsulc, as currant, grape, cucumber, melon.

7. Strobile. An ament with woody scales, as the fruit of the pine.

\section{Subdrvisions of TIIE SEED.}

1. Cotyledon. The thick fleshy lobes of seeds; very manifest in beans, whose cotyledons grow out of the ground in the form of two large succulent leaves. Many plants, as Indian corn, wheat, the grasses, \&c. have but one cotyledon; mosses, \&c. none.

2. Corcle. The rudiment of the future plant, always proceeding from the cotyledon; easily distinguished in chesnuts, acorns, \&cc.

3. Tegument. The skin or bark of seeds; it separates from peas, beans, Indian corn, \&c. on boiling.

4. Hilum. The external mark or scar on seeds, by which they were affixed to their pericarps. In beans, and the like, it is called the eye.

\section{Subdivisions of the Receptacle.}

1. Proper. That which belongs to one flower only.

2. Conimon. That which connects several distinct florets, as in the sun-flower, daisy, teasel. A common receptacle may be,

3. Rachis. The filiform receptacle, connecting the florets in a spike, as in the heads of wheat.

4. Columella. The central column in a capsule, to which the seeds are attached.

5. Spadix. An elongated receptacle, proceeding from a spathe, as $\mathrm{In}$ dian turnip.

\section{General Divisions of Flowers.}

1. Simple. Having a single flower on a receptacle, as in the quince, tulip, \&c.

2. Aggregate. Having on the same receptacle several flowers, whose anthers are not united, as teasel, buttulı-bush, \&cc.

3. Compound. Having several florets on the same receptacle, with their anthers united, as sun-flower, china-aster, \&c.

4. Staminate. Having stamens only, as those in the tassels of Indian corn.

5. Pistillate. Having pistils only, as the fertile flower of the cucumber.

6. Perfect. Having both stamens and pistils.

7. Neutral. Haviug neither stamens nor pistils.

8. Complete. Having a calyx and corol.

\section{INFLORESCENCE.}

The manier in which Flowers are situated on Plants.

1. Whorl. In which the flowers grow around the stem in rings one above another, as mother-wort, catnip. 
2. Raceme. Having the florets on short undivided pedicels, arranged along a general peduncle, as currants.

3. Panicle. Having some of the pedicels, nlong the general peduncle of the raceme, divided, as in onts. A panicle contracted into a compact, somewhat ovate form, as in lilac, is called thyrse.

4. Spike. Having the forets sessile, or nearly so, on the elongated general receptacle, as wheat, mullein, \&c.

5. Umbel. Having the flower-stems diverging from one place, like the braces of an umbrella, bearing florets on their extremities, as carrot, dill, fonnel, \&c.

6. Cyme. It agrees with the umbel in having its general flower-stems spring from one centre, but differs in having those stems irregularly subdivided, as elder, \&c.

7. Corymb. In the corymb the peduncles take their rise from different heights along the main stem; but the lower ones being long. er, they form nearly a level or convex top, as yarrow.

8. Fascicle. In general external appearance it resembles the umbel, but the foot-stalks are irregular in their origin and subdivisions, as sweet-william.

9. Head. In this the flowers are heaped together in a globular form without peduncles, or with very short ones, as clover.

\section{Concentric Cyuinders of Roots and Herrage.}

The Substance of Roots and Herbage consists of:

1. Cuticle. The thin outside coat of the bark, which seems to be without life, and often transparent. Very conspicuous on some kinds of birch, cherry, currant-bushes, \&c.

2. Cellular Integument. The parenchymous substance between the cuticle and bark, generally green. Easily seen in the elder, after removing the cuticle.

3. Bark. The inner strong fibrous part of the covering of vegeta. bles.

4. Camb. The mucilaginous or gelatinous substance, which, in the spring of the year, abounds between the bark and the wood of trees.

5. Wood. The most solid part of the trunks and roots of lierbs and trees.

6. Pith. The spongy substance in the centre of the stems and roots of most plants. Large in the elder.

Roots.

Foots are the descending parts of vegetables, and are annual, biennial, or perennial. They are of seven kinds.

1. Branching. Having the whole root divided into parts as it proceeds downwards, as the oak, apple-tree, \&zc.

2. Fibrous. The whole root consisting of filiform parts, originating immediately from the base of the stem, as many of the grasses.

3. Creeping. Extending itself horizontally, and sending out fibrous radicles, as quack-grass.

4. Spindle. Thick at the top, and tapering downward, as carrot, parsnip, \&e.

5. Tuberous. Roots which are thick and fleshy, but not of any regular globular form. They are knobbed, as the potatoe; ov'al, as those 
of orchis; abrupt, as the birdsloot violet; or fuscicled, as aspara. gus.

6. Bulbous. Fleshy and spherical. They are either solid, as the tur nip; coated, as the onion; or scaly, as the garden lily.

7. Granulated. Consisting of several little knolss in the form of grains, strung together along the sides of a filiform radicle, as the wood-sorrel.

HERDAG is all the plant except the root and fructification. It in. cludes stems, leaves and appendages.

STEars.

1. Tige, or proper stem. The ascending herbage-bearing trunk or stem of all phenogamous plants, except the grasses, as the trank of the oak, the grape vine, the mullein stalk.

2. Culm. The stalk or stem of the grasses, as wheat-straw, sugarcane, \&c.

3. Scape. That kind of flower-bearing stem which springs immediately from the root, and is destitute of leaves, as dandelion.

4. Peduncle. The flower-bearing stem which springs from any part of the stem or branches, as apple, cucumber, \&c.

5. Petiole. The foot-stalk of the leaf.

6. Frond. Applied entirely to cryptogamous plants. It includes the herbaceous, leathery, crustaceous, or gelatinous substance, from which the fruit is produced.

7. Stipe. The stem of a fern, of a fungus, of compound egret, and of a pericarp when elevated from the receptacle; as of maiden-hair, garden caper.

Leaves are evergreen or deciduous.

Forms of Simple Leaves.

1. Orbicular. Nearly circular, as the leaves of red clover, of cabbage, \&c.

2. Ovate. Resembling the longitudinal section of an egg, the base leing broader than the extremity. One of the most comenon form: of leaves.

3. Oval. Differing from ovate in having both ends equal in breadth.

4. Oblong. The length more than twice the breadth, and the sides somewhat parallel.

5. Obovate. Ovate with the narrowest end towards the stem, as those of red clover.

6. Cordate. Heart-shaped, the hind-lobes being rounded, as lilac.

7. Obcordate. Cordate, with the apex or narrowest end towards the stem, as of wild indigo.

8. Kidney-form. Hollowed in at the base, with rounded lobes and rounded ends, as mallows.

9. Lanceolale. In the form of the ancient lance, tapering from near the base to the apex, and narrow, as the leaves of most of the willows, of ribw ort, \&c.

10. Linear. Continuing of the same width through nearly the whole length ; usually pointęd at one or both ends, as most grasses.

11. Awol-form. Linear at the base, and becoming more or less cursed at the point. 
12. Acuminate. Any kind of leaf terminating more or less suddenly in a point turned towards one edge of the leat.

13. Arrow-form. Shaped like an arrow-head; differing from cordato in having the hind-lobes more or less acute.

14. Hulberl-form. Hastate. Shaped like on halbert, as field-sorrel, c reeping snapdragon.

15. Guilar-form. Oblong, broadish near the base, and contracted at the sides.

16. Lobed. Deeply parted, and the divisions large, with rounded sides or ends, as the white oak.

17. Palmate. Resembling a hand with the fingers spread, as horse. chesnut.

18. Pedate. Resembling a bird's foot.

19. Sinuale. Having the margin hollowed with deep sinuses or bays, as the white oak.

20. Pinnatifid. Divided transversely by deep ineisions, not extending to the midrib.

21. Lyrate. Pinnatifid, with the largest division at the apex, and diminishing from thence to the base, as hedge-mustard.

22. Runcinate. Pinnatifid, with the divisions prointing backwards, as dandelion.

\section{Edges of Leaves.}

23. Serrate. Having sharp notcles resembling saw-teeth along the margin, and pointing towards the apex, as those of cherry-trees, roses, \&c.

24. Toothed. Having projections from the margin of its own sul)stance, which are neither serratures, nor crestatures, as those of blue-bottle.

25. Crenale. Having uniform notches on the margin of the leaf, which incline towards the apex, or the base, or neither, as gill-overground.

\section{Exps of Leaves.}

26. Emarginale. Notched at the termination of the midrib.

27. Retuse. Emarginate with a shallow sinus.

28. Obluse. Having the apex of the leaf more or less rounded.

29. Acule. Terminating in an angle; that i3, not rounded.

\section{Surfaces of Leaves.}

1. Hairy. Having distinct strait hairs.

2. Downy. Covered with fine cotton-like down.

3. Silky. Covered with soft close-pressed hairs.

4. Bristly. Set with stiff hairs.

5. Ciliale. Edged with parallel hairs or bristles, resembling eye. lashes.

6. Nerved. Furnished with midrib-like fibres running from the base to the apex.

7. Veined. Having tendinous fibres variously branched.

Positions of Leaves.

1. Decurrent. When the two edges of the leaf extend along the stem below the place of iusertion. 
2. Clasping. Sessile with the base more or less heart-form, so as entirely or in part to surround the stem.

3. Sheathing. With the leaf prolonged down the stem, so as to cover it, in the manner of the grasses.

4. Perfoliale. Having the stem passing through the leaf.

5. Connate. Leaves opposite, with their bases united.

b. Pellate. With the foot-stalk attached to the lower side of the leal, so as to resemble a shield.

7. Opposite. Standing at the same height with base against base.

8. Wharled. Surrounding the stem in horizontal rings or rows.

ข. Imbricale. Lying over each other like shingles on a roof, so as to "break joints."

10. Fascicled. Growing in bunches from the same point, as Jeaves from white pine.

11. Ralical. Procceding immediately from the root.

\section{Compound Leavis.}

1. Ternate. IIaving three leafets proceeding from the end of one petiole.

2. Biternate. Twice ternate; when the petiole is ternate, and each division bears three leafets.

3. Triternate. Three times ternate.

4. P'innate. With distinct leafets arranged on opposite sides of the same petiole.

5. Bipinnate. Twice pinnate.

i. Tripinnate. Thrice pinnate.

7. Intcruptedly-pimate. Having smalter leafets dispersed among the larger, as potatoe.

\section{APPEXDAGES.}

1. Stipule. A leafet or scale at, or near, the base of a petiole.

4. Bract. A leaf among or near the flowers, different from the othes' leares of the plant.

3. Thorn. A sharp process froun the woody part of a plant.

4. Prickle. A sharp process from the bark, as those on rasplerry bushes, \&ac.

5. Sling. Hair-like processes mostly from the leaves, as nettles. 6. Gland. A roundish, generally minute, appendage to different parts
of plants.

7. Tendril. The filiform appendage by which climbing plants support themselves oul other bodies.

NUMERALS.

The Latin and Greek numerals are so frequently compounded will: other words by botanical writers, that an English student ought to commit ther to memory, as here laid down. 
1.ATIS. NOS. GREEK.

\begin{tabular}{|c|c|c|c|c|}
\hline Unus & - & - & 1 & Monos \\
\hline Bis & - & - & 2 & twice. \\
\hline Tres & - & - & 3 & thrice. \\
\hline Quatuor & - & - & 4 & Tettares \\
\hline Quinque & - & - & 5 & Pente \\
\hline Sex & - & $=$ & 6 & Ex (pronounced hex) \\
\hline Septem & - & - & 7 & Epta (pronounced hepta) \\
\hline Octo & & - & $\mathrm{S}$ & Okto \\
\hline Novem & - & - & 9 & Eunea \\
\hline Decem & - & - & 10 & Deka \\
\hline Undecem & & - & 11 & Endeka \\
\hline Duodecen & & - & 12 & Dodeka. \\
\hline Tredecem & & - & 13 & Dekatre is \\
\hline Quatuordecin & & - & 14 & Dekatettares \\
\hline Quindecim & & - & 15 & Dekapente \\
\hline Sexdecim & & - & 16 & Dekaex \\
\hline Septendecim & & - & 17 & Dekaepta. \\
\hline Octodecim & & - & 18 & Dekaokto \\
\hline Novendecim & & - & 19 & Dekaennea \\
\hline Viginti & - & - & 20 & Eikosi \\
\hline Multus & - & - & Many & Polus \\
\hline
\end{tabular}

\section{LINNEAN CLASSIFICATION.}

Plants are e? ssified upon two distinct plans; the Artificial and $\mathrm{Na}$ tural. The $o b_{j}$ of the Artificial system is merely to furnish a method for ascertaining the name of a plant. The object of the Natural system is to bring together into small groups, plants which resemble each other in their botanical affinities, sensible qualities and inedicinal properties. The Artificial system has been very aptly compared to the dictionary, and the Natural to the grammar of a language.

\section{Artificial System.}

The art of searching out the name of a plant is denominated the analysis of the plant. It is, in truth, an elegant illustration of the Analytical method of logic; as the construction of a genus, order and class, is of the Synthetical method.

When we analyze a plant by the aid of the nitificial system, our final purpose is to ascertain the specific name, by which it was callect by the first botanist, who published a description of it. But in doing this, we trace it through several intermediate steps. Species are grouped together under generic names-genera under orders-orders under classes. By this arrangement much labour is saved. For example, we see the common wild strawberry, for the first time; and are de. sirous to learn its name. By comparing the proper organs (to be described hereafter) with the description of the classes, we find it belongs with the group of plants, which constitute a class, called Icosandria. This class is subdivided into orders, and we find our plant is to be referred to the order Polygynia. Here we find the names of several genera-such as the rose, the raspberry, the strawberry, the five-finger, the avens, \&xc. On comparing our plant with all the genera under this order, we find it will agree with none but the strawberry. 
On turning to the strawberry (under the botanical name firagaria) we find there are several kinds of strawberry. Lacls kind is called a species, as the Finglislı strawberry, haut-boy strawberry, pine-apple strawberry, wilt strawberry, \&ec. are different species. On carefully comparing sur plant with the descriptions of all the species, we find it will agree with none but, the wild strawberry (virginiana.) Thus we arrive at the generic name strawberry, (fragaria) and specific name wild, (veruiana)

The Lirnean Artificial classes are founded upon the four following circumstances of the stamens; number, position, relative length, and conizexion. The first ten classes are distinguished by the number of struens-the elerenth and lwelfth by number and position-lhe thirteentio and fourteeuth by number and relative length-the fifieenth, sixteerth aud seventeenth by connexion-the eighteenth, nimeteenth and treentieth by position The last or twenty-first class, being a nntural one, is not distinguished by any circumstance of the sta, inens.

The first twelve classes are named by prefixing Greek numerals expressive of the number of stamens to ANDRIA; which is a Greck dericatice, used metaphorically for stamens.

1. MONANDRIA, includes thinse plants which bear perfect flowers, with but nne stamen in each. As the blite and sampbire. It is a very small class.

2. DIANDRIA, includes those plants which bear perfect fonwers, with two s amens in each. As hedge-hyssop and lilac. Part of this class of plants bears raked seeds, and forms a natural union with those of the first order of the fourteenth class; as sage, rosemary, mountain mint.

3. TRIANDRIA, includes those plants which bear perfect flowers, with three stamens in each. As the iris and oats. Most of the grasslike or culmiferous plants are included in this class The rough coarse grasses, as bog-sus! and cotton grass, which have closed sheaths or no sheaths to the leaves, have but one style to the pistil. But the finer grasses, as timothy grass and blue grass, which have open sheaths to the leaves, have two styles.

4. TETRANDRit, includes those plants which bear perfect flowers, with four stamens in each As plantain and dog-wood. Tlis class is wholly artificial, consequently the plants included in it are easily found out.

5. PENTANdria, includes those plants which bear perfect fowers, with five stamens in each. As comfrey, mullein, tobacco, potatoe, ginseng, parsnip, elder and flax. This is a very extensive class. It includes a natural assemblage of rough-leaved plants, as the borageof nauceous narcotics, as tobacco and henbane-of umbelliferous narcotics and stomachics, as poison hemlock, water-parsnip and fenuel-also many plants which greatly disagree in botanical affinities. The rough-leaved and umbelliferous plants of this class resemble each. other so nearly, that students find much difficulty in distinguishing the genera.

6. HEXANDEIA, includes those plants which bear perfect flowers, with six stamens in each. As the lily, tulip, dock and water plan. tain.

7. HEPTAXDRTA, includes those plants which bear perfect flowers, with seven stamens.in each. Is the chick winter-green and horse- 
chesnut. This is a very small class, ard the numier of stamens variable in most flowers found in it.

8. OCTANDRIA, includes those plants which bear perfect flowers, with eight siamens in each. As the marsh crarberly, nastustion and buckwheat.

9. ENNEANDRia, includes those plants which bear p.erfect finwers, will nise stamens in each. As the sassafras and rlubarb. It is a small class, and the number of stainens very variabie in all the flowers found in it.

10. Decandria, iucludes those plants $w$ bir li bear perfect finwers, with ten stamens in eacb. As tle whonllolering. rink, corkle and pokeweed. Some flowers in this class have but balt the nunber of stamens required in part of the specis s of a gellus.

11. I $\cos A N D R i a$, includes those plants which bear yerfect flowers, with more than ten strmens in each, grouing or the caly $x$ As the peacli, apple, thorn, strawberry and rose. Sone flower in this class have but balf the number of stamens required; as some species of thorn, \&c. It is called Icosandria, because the average tun. Ler of stamens is about tis enty.

12. Polyandiria, ii.cludes llose plants which bear rerfect flowers, with stamens more numerous getieraliy than thuse of ary other class, growing on the receptacle; as the pond lily and con nou st. John's wort. If the number of stamens exceeds ten, yrovided they are placed on the receptacle, the plant belongs to this class. This is an extensive class, and the number of stamens is more variahe in this than in all the other classes. When several flowers on the stme plant have a variable tumber of stamens placed on the receptacle. he n.4y geverally presume that the plant belongs to this class, even if $t+w$ are found with so many as ten stamens.

The thirleenth and fourtcenth classes are named ly prefixing the Greek numerals, expressive of the number of long stamens, to DYAAMIA; which is a Greek dcrivative, signifying power,-importing that the longest slamens are most powerful.

13. Dinvamia, includes those plants which bear perfect flowers, with four stamens in eacb, two of which are lengtst; ss savoly, skullcap, snardragon. This class embraces plants of two very natural assemblages. The first order rentair s plants with I ahed sefds; tone of which are poisonous. The second ordcr contains flants with seeds in capsules, all of which are said to be poisolicus. Most flowers of both orders liave labia'e corols.

14. Tetradynamia, includes those plants which bear perfect flowers, witb six stamens in each, four of whech ast lowest; as n u:tard, cabbage and radish. This class embraces a vely natural fanily of plants, bearing cruciform flowers.

The fifteenth and sixtcenth classes are named by prcfixing Greek numerals, expressite of the number of jarccls in uhich the stamens are united by their filaments, to the uord ADELPHIA; which is a Greek de. ricative, used to signify brotherhood.

15. Monadelphia, includes those plants which bear flowers, whose stamens are united laterally by their flaments in oue group or set; as 
the hollyhock and mallows. but if the flotrers are papilionaceous, they belong to the next clasa, even if the stamens are so united; as the lupine. Some species of genera which belong to this class, lave the stamens broad and membranous at the base, but not attached at all; as some species of geranium. They generally recede from the hase of the petals, by approaching the pistil, presenting a columnar form.

16. Diadelphia, includes those plants which bear perfect flowers, whose stamens are united laterally by their filaments in two groups or sets; as the pea, hean, ard locust-tree. In most cases nine stamens are united in one set, and one stamen stands alone. In some flowers the stamens are all united in one set, which is the proper claracter of the preceding class; though if the corol is papilionacenus, it belongs here. But if the stamens are not united at ali, the plant does not belong here, even if the corrl is papilionaceons; as the cassia and wild indigo belong to the tenth class. Genera of the tenth order in this class resemble eacli other so nearly that students find considerable ditficulty in distinguishing them.

The serenteenth class is named by prefixing sy, (a Greek deriratire from sun,) signifying together, to GENAS1A, a Greel derivative, signifying produced or growing up. The name is intended to signijy that ihe anthers grow up logether, or in an united state.

17. Syngenesia, includes those plants which bear perfect, staminate, pistillate, or neutral ficrets, in which those bearing anthers have them united laterally, so as to form a hollow cylinder. 'Io this definition should be added, that the plants of this class all bear compound flowers, as the sun-flower, thistle, and dandelion, to exclude the lobelia, some species of violet, the jewel-need, dic. " hich belong to the fifth class, though their anthers are united. 'Tlis is a very extensive and perfectly natural class.

The cightecnthelass is named by prefixing an abbreviation of GYNIA. a Greek dericatire, used melaphoricalty to signify the pistil, to ANDRIA; as the stamen and pistil are united in this elass.

18. GYNANDRI, includes those plants which hear perfect flowers, with the stamens standing on the pistit; as ladics'slipper and orchis. To this definition should he added, that the stamens are inserted at a distance from the place where the calyx and corol are inserted. For the stameus are inserted on the germ of the pistil in all plants of the class SYNGENESIA, \&c. but they are inserted in connexion with the Gorol.

The ninetcenth and tuentieth classes are named by prefixing Greck numerals cxpressire of the number of plants oceupicd by the stamens and pistils in order to complete a spccies, to $₫ \mathrm{cls}$, a Greck derizative from oikos, a house. The name is inteuded to signify, that the stamons and pistils inhabit the sume or different tencments.

19. MON\&CIA, ineludes those plants which bear imperfect flowers, with the staminate and pistillate flowers on the same plant; as the oak, chesnut, and Indian corn. 
20. DiєcrA, includes those plants which bear imperfect fowers, "ith the staminate and pistillate flowers on separate plants; as the hemp, hop, willow and poplar.

Nost plants of these two last classes are united in one class by Pursli. calted Diclinin. Plants of these two classes may be called dicliniouti. plants, or the diclinious classes.

The twenty-first class is named by prefixing cгурто, a Greek derivatire, signifying concealed, to GAMIA, "Gireek derivative, used metaphorically ior the strewing of pollen from the anthers upon the stigmas of pistils. Ii: is intended to signify, that the operation of strewing the fertilizing pol. len upon stignias, so manifest in lilies, poplars, Indian corn, fic. is conccaled in plants of this class; though it is probable that such operations ure as regularly perfurmed in cryptogamous as in phenogamous plants.

21. CRY PTOGanis, includes those plants whose stamens are not masifest, even under the leus. They are kuown by habit, or natural af. tinities; as ferns, mogses, liver-worts, sea-weeds, lichens, and fungi.

Rcmarks. 'To ascertain the number of stanens contained in the llowers of plants, in dificult cases, the student nust consider their re. lation to the divisions of the corol, or of the calyx if the corol is wanting. For if the stamens are all arranged around the pistil in one cir cular series, they agree in nunber witb the divisions of the corol; or their number is such that they may be divided by the nunber of the divisions of the corol, or that these divisions may be divided by the number of stamens, without any remainder. If the stamens are arrungad in more than one series, each series, separately taken, is snbject to the same rule. Thus all criciform flowers have two series of stamens. The inner series consists of four stamens, which is equal to the number of petals. The outer series consists of two stamens, by which the number of petals may be divider without a remainder.

In some cases the inner series seems to be governed by the pistil; particularly when the orincipal series is outermost. As in the buckwheat. Here the main series is outermost, and consists of five stamens, agreeing with the divisions of the coloured calyx. The innev series consists of three stamcns, agreeing with the triangular form of the germ. One species of this genus (orientale) has a two-sided gern ; and the inner series consists of lut two stamens.

By a careful attention to such relations or analogies, we may $\mathrm{fx}$ upon the right number for detcrmining the class, in cases wbare the real number of stanens is very variable, or where they are partly abortive, or too minute for the eye.

\section{AFTIFICIAL ORDERS.}

Fach class is subdivided into two or more orders. These aubdivisions are founded upon the number of styles (or stigmas when styles are wanting) - the covering or nakedness of seeds-the relative lengths of pods-the comparison betweer clisk and ray florets of compound flowers-and the characters of preceding classes. The orders of the : lass cryptogamia are distinguished by natural fumily characters. 
The orders of the first tuclec clasies are distinguished by the number of styles : and named by prefixing Gircek numerals, expressite of the num. ber of slyles, 10 GYN1A, "Grcek lerivative, used metuphuricully for slyls or stigma. The styles are numbered at their origin on the germ. Their subdivisions abore the germ are not taken into ricw in delermining the number of the order. Sometimes the style is wanting, lcating the stig. ma to sit down upon the germ; in such cases the stigmus are numbered in determining the number of the order.

1 Monogyna, includes those plants, in any of the first twelve clas. ses, which bear flower's with but one style, or one sessile stigina in each; as the samphire in the first class, the lilas in the second, the iris in the third, the plantain in the fourtb, the multein in the fifth, the lily in the sixth, the horse chesnut in the seventh, the scabish in the eight, the sassafras in the niuth, the prince's pine in the tenth, the cherry in the eleventh, and the poppy in the twelfih.

2. Digrais, inclindes those planis, in any of the first twelve classes, which bear flowers with two styles, or two sessile stigmas in each; as timothy grass in the third class, and the pink in the tenth class.

3. Trugynia, includes those plants in any of the first twelve classes, which bear flowers with three styles, or three sessile stigmas in each ; as the elder in the fifth class, and the buckwheat in the eighth class.

4. Tetragyna, includes those plants in any of the first twelve classes, which bear flowers with four styles or four sessile stigmas; as the holly in the fourth class, and the lizard's tail in the seventh class.

5. PxNTagria, includes those plants in any of the first twelve classes, which bear flowers with five styles or five sessile stigmas in each; as spikenard in the fifth class, and cockle in the tenth class.

6. HEXAGYN1A, sir styles or sessile stigmas.

7. HEPтAg YNia, seren styles ur sessile stigmas.

8. OctogYNiA, eight styles or sessile stigmas.

9. ENNEAGYia, nine styles or sessile stigmas.

10. Decagynis, includes those plants in any of the first twelve classes which bear perfect flowers, "with ten styles or ten sessile stigmas in each; as the pokeweed in the tenth class.

13. Polygysia, includes those plaits in any of the first twelve class. es which bear flower's with any number of styles or sessile stignias above ten; as the rose in the tivelfth, and the crnw-foot in the thirteenth.

The orders of the thirteenth and fourtecnth classes are but two in each. Those in the thirleenth are named by prefixing GYnNo, a Grcek deriva. tive, signifying naked, or ANG10, a Greek derivalive, signifying bag or sack, to SPERMIA, a derivative signifying seed. In the fourteenth, they are named by using a derivative from the Latin S1LiquA, a pod; and from the diminutive of the same, SiLicuLA.

1. Gramospermis, includes those plants of the thirteenth class, which bear seeds without any pericarp. They generally lie naked in the bottom of the calyx ; as of mother-wort and hyssop.

2. ANGIOSPERMA, includes those plants of the thirteenth class, which bear seeds in a capsule; as the fox-glove al; snapdragoll.

1. Siliculosa, includes those plants of the fourteenth class which bear silique pods, with the length and breadth nearly eqaal; as the sliepherd's purse. 
2. Simiquoss, includes those plants of the fourteenth class which thear silique pods, with the length considerably esceeding tho breadth, alivays more than double; as the mustard.

The orders of the fifteenth, sixtcenth, eighteenth, nineteenth and twentieth classes, are distinguished by the characters of preceding classes, and. ressume the same numes Therefore when a plant is found in either of these fice classes, we inquirc which nearest preceding class it would fall into, if its particular elassic eharacter were wanting. The answer to this inquiry gives the order.

1. MoNANDRis, when used for an order in the $151 \mathrm{~h}, 16 \mathrm{th}, 18 \mathrm{~h}, 19 \mathrm{th}$, or 20 th class, includes those plants in either of said classes which bear fowers with but one stamen in each; as orchis in the eightecnth class, and sea eel-grass in the nineteenth.

2. Draspras, when used for an order in the 15th, 16th, 18th, 19th, or 20 th class, includes those plants in either of said classess which bear. fowers with two stamens in cach ; as ladies' slipper in class 18 , duckmeat in class 19, and willow 13 class 20.

3. Tusandms, when nsed for all order in the $15 \mathrm{th}, 16 \mathrm{th}, 18 \mathrm{hh}, 19 \mathrm{th}$, or 20 th class, includes those plants in either of said classes which bear Aowers with three stamens in each; as blue-eyed grass in class 15, Indian corn in class 19, and the fig in class 20.

4. Irrrannia, when ased for an order in the $15 \mathrm{~h}, 16 \mathrm{~h}, 18 \mathrm{~h}, 19 \mathrm{ht}$, or 20 th class, inciudes those plants in cither of saicl classes which hear nowers with four stamens in each; as the nettle in the 19th elass and the bayberry in the zuth class.

E. PESTANDMA, when used for an order in the $15 \mathrm{th}, 16 \mathrm{th}, 18 \mathrm{th}, 19 \mathrm{th}$, or 201 li class, includes those plants in either of saicl classes which bear fowers with five stanens in each; as the passion-fiower in the 15th class, the hog-weed in the 19t:", and the hemp in the 20 th.

6. HexixDR1d, when used fur an order in the 15th, 16th, 19th, 19th, or 2oth class, includes those plants in either of said classes which bear slowers with six stamens in each; as water-oats in the 19th class, and the green-briar in the 20th.

7. HEPla YDR1, when used for an order in the $15 t_{h}, 16 t h, 18$ th, 19 th, or 20 th class, inclndes those plants in either of said classes which beat fower's with seven stamens in each; as the stork-geranium in class 15.

8. OctaknRIA, when used for an order in the 15th, 16th, 18th, 19th: or 20 th class, includes those plants in either of said classes which bear flower's with eight stamens in each; as the seneca snakc-root in class 16 , and poplar in class 20.

10. Decandria, when used for an order in the $15 \mathrm{th}, 16 \mathrm{th}, 18 \mathrm{th}, 19 \mathrm{th}$, or 20 th class, includes those plants in either of saicl classes which bear flowers with ten stamens in each; as the geraniun in class 15, and the pea in class 16 .

13. Poryandria, when uged for an order in the 15 th, $16 \mathrm{th}$, 15th, 19 th, $n$ r 20 th class, inclucles those plants in eillier of said classes which bear flowers with more than ten stamens in each; as the hollyliock in class 15 , the butternut in class 19 , and the moon-seed in class 20 .

16. NIOAADERPIA, when used for an order in the 19th or 20th class, (it is never used in 16 th, 16 th, or $19 t h$ ), includes those plants in cithe: 
rf said classes which bear flowers with the stamens anited by their filaments in one set; as the cucumber in class 19, aud the red cedur in class 20 .

The four first orders of class 17, ato distinguishel by comparing th, risk and ray florc's. The first, sccond and lhirl orders hate perfect florets in the tisk; the fourth has slaminute flore!s only in the disk. The: irst has perfoct florets iu the ray. the scoud and fourlh hate pistillate. und the thir thas nculral. The fifth order has parlial perianth caly.tes l" all the flore's; whercas none of the other order's hace any but the general 'aly.x-the egre', when present, being a substitule jor the perianth. The

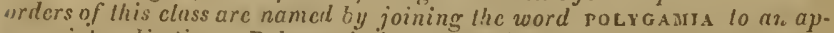
")opriale arljeclice. Polygamia is a Greck derivative, used neluphorienlIy to signify numerous organs for carrying on the process of sirewing the ferlilising pollen upon stigmes. The adjeclive savsLes is uscd to signify. thet line organs for fuinishing "ollen are equalized, or duly proportionen! to the sligmas to be forlitiacl; superfuva, that lige pistillate florets in the margin or ray are supcrfuous, cach ferlile floret of the aisk haring stamens and pistits in due rroportion; risusTkANEA, ihat the ray florel.x arc emply or vain, having no slamezs or pistils; NECEssania, that the ray llorels nic reccssary to the production of seed, the aish florcls tring all staniinale: SLGRFGATA, that the florets are disjointed, or scparated from ruch olher by parlial calyxes.

1. Polygams mevaris, includes those plants of the 1\%th class, which boar flowers with perfect lorets in both the disk and ray; us Ise dandelion, thistle, and burdock.

2. PoLrgamia superzidun, includes those plants of the $1 \%$ th class. which bear flowers with perfect liorets in the disk, and pistillate forets in the ray: as ox-eyed daisy and yarrow

3. P'OLXGAML FRUSTANEA, includes those plants of the 17th class, which bear flowers with perfect florets in the disi, and neutral florets in the ray; as the suri-llower and blue-botile.

4. Poirgama necessaria, includes those plants of the 17 th clase, which hear flowers witl: staminate florets in the disk, and pistillate lorets in the ray, as the pot-marygold, and high-ivater shrub.

5 Poirgania segrigata, includes those plants of the 17 th clase, which bear flowers with a perianth to each lloret; as the globe-thistle, aid elephant's foot

The orders of the twenly-first closs are distinguished by natural family characters : this class embraces six. nalural familics.

1. Fizices, includes all the ferns. These plauts bear fruit on the istek of the lenves, or some part of the leaves seem as it were meta. morphosed into a kind of fruit-bearing spike; as the brake; and mai. den-lıair. A sub order, which may be denominated Apteres or Plcroires, includes those which bear iruit in a peculiar appendage, as a spike or jorotuberance in the axils or at the base of the leaves; as ground pine, scouring-rush, and quill-wort.

2. Moscr, includes the proper inosses. These plants bear, on leafy stems and branches, one-celled crpsules opening at the top, where, they are crowned by a peculiar lid. The capsules do not open by valves, and are generally elevated on stems or stipes: as hair-cap 1.105s. 
3. Hipatic.5, includes those more succulent moss-like plants, which are called liver-worts. They bear four-valved capsules, which distinguishes the in from inosses; as brook liver-wort, and platted moss.

4. AlGE, includes the sea-weeds and frog-spittle. These plants hear vesiculous or filamentous fruit, mostly in gelatinous fronds. The fruit frequently requires a liigh magnifying power to render it visible; as common sea-weed, and river green-hair.

5. Lichenes, includes the proper lichens. These plants appear in somewhat circular patches on stones, trees, and old fences; also in fibres suspended from branches, \&cc. They are generally pale green, yellow, white, or black; but they are found of all colnurs. 'They bear exceedingly minute fruit in receptacles on compact or gelatinous frond3. These receptacles are divided into twelve kinds, translater. by Dr. J. E Smith into clefts, spangles, puffs, buttons, tubercles, hollows, cellules, globules, shields, turgets, orws, and knobs. All of these terms are separately defined in the Dictionary.

6. FUXGI, includes such plants as the mushroom, toucliwood, mould, blight, Ac. They are destitute of herbage, consisting of a spongy, pulpy, leathery, or woody substance; and bear fruit in a naked d!lated inembrane, or within the substance of the plant.

Remark. For a more full account of these six last orders, the reader is referred to the Natural Oiders of Jussieu.

$N$. $B$. When a $\operatorname{star}\left({ }^{*}\right)$ is placed before generic names at the end of an order, it is to be understood, that though some species of these genera lall here by the rules of the artificial system, yet that as no natural genus must be divided, these stragglers must be referred back to their natural genera for descriptions. They may thus be referred back by aid of the alphabetical arrangement of generic names, where the species are described.

Note 2. When exercising pupils in the artificial classes, the Instructor should direct them to begin by comparing the stamens of the plant under examination, with the characters of the higliest numbered class, and to proceed downwards towards the first class. Hecause the characters of the lower classes are sometimes included in the higher. Thus, in analyzing the lily, the student should proceed as follows.

1. It is not cryplogamous, because the stamens and pistils are manfest.

2. It is not diclinious, because the stamens and pistils are inthe same flower.

3. It is not gynandrous, because the stamens do not stand on any part of the pistil.

4. It is not syngenecious, for the flower is not compound.

5. It is not adelphous, for the filiaments are not united.

6. It is not dynamous, for two stamens are not uniformly the sliortest.

7 . It it not hyperdecandrous, for the number of stamens does not exceed ten.

8. It is not decandrous, for the number of stamens is not ten.

9 . It is hypodecandrous, for the number of stamens is under ten.

Having traced it to the proper group of classes, the exact number of stamens settle it in the class hexandria. 


\title{
SYNOPSIS OF ARTIFICIAL CLASSEE
}

\author{
1. Monandria, one stamen in the dower. \\ 2. Diundria, 2 stamens. \\ 3. Triandria, 3 stamens. \\ 4. Tetrundria, 4 stamens. \\ No. of 5. Pentandria, 5 stamens. \\ stamens. 6. Hexandria, 6 stamens. \\ 7. Heptundria, 7 stameus. \\ 8. Octandria, 8 stamens. \\ 9. Eineardria, 9 stamens. \\ 10. Decandria, 10 stamens.
}

10. and 11 . Icosandria, more than ten stamens, standing on the caly $\mathrm{x}$. position. $\{12$. Polyandria, more than ten stamens, on the receptacle.

No. and $\{13$. Didynamia, 4 stamens, 2 of them uniformly the longese.

length. $\{14$. Tetradynamia, 6 stamens, 4 of them uniformly the longest.

15. Monadelphia, stamens united by their filaments in one set, anthers generally separate.

Connex. 16. Diadelphia, stamens united by their filaments in two sets, ion. sometimes in one set, with papilionaceous corols.

17. Syngenesia, stamens 5 , united by their anthers in one $6 \mathrm{ct}$, flowers compound.

18. Gynandria, stamens stand on the germ, style or stigma, separate from the base of the calyx and corol.

Pcsition. 19 Bhoncecia, stamens and pistils in separate flowers on the same plant.

20. Dicecia, stamens and pistils on separate plants.

Nalural. $\left\{\begin{array}{c}21 . \text { Cryptogamia, stamens not manifest, such plants can only } \\ \text { be classed by natural families. }\end{array}\right.$

Remarks. Culmiferous plants, of the $3 \mathrm{~d}, 6$ th and 19 th classeg, must be in fruit, almost mature, when analyzed. Also, all plants in classes 11, 13, 14 and and the umbelliferous, in the 5th. The classes, orders, and most of the generic characters in these classes, may be ascertained after the fruit is suficiently mature for anslyzing. 


\section{SYNOPSIS OF ARTIFICIAL ORDERS.}

Class 1.)

3. Orders of these twelve classes are distinguished by the num.

4. ber of styles or sessile stigmas.

6. Monogynia, 1 style. Digynia, 2.

7. Trigynia, 3. Tetragynia, 4.

8. Pentagynia, 5. Hesagynia, 6.

9. Heptagynia, 7. Octogynia, 8.

11. Decagynia, 10. Polyginia, over 10.

32.

13. 1, Gymnospermia, seeds naked. 2, Angiospermia, seeds corered.

14. 1, Siliculosa, pod short. 2, Siliquosa, pod long.

15. Preceding classes, as 1, Monandria. 2, Diandria. 3, Trian16. dria. 4, Tetrandria.

17. 1, Polygamia aequalis, florets all perfect. 2, Pol. superfue, florets of the disk perfect, of the ray pistillate. 3, Pol. frustranea, florets of the disk perfect, of the ray neutral. 4, Pol. necessaria, Alorets of the disk staminate, of the ray pistillate. 5, Pol. segregata, fiorets furnished with partial calyıes.

18. Preceding classes, as 5, Pentandria. 6, Hexandria. 7, Hep. 19. tandria. 8, Octandria. 10, Decandria. 13, Polyandriz. 20.) 15, Monadelphia.

21. 1, Filices (ferns, brakes, polypods.) 2, Musci (common mosses.) 3, Hepaticx (liverworts and succulent mosses.) 4, Algae (frog-spittle, water greenhair, sea-weeds.) 5 , Lichenes (lichens, dry mosses, patches and specks on trees, rocks, stones, \&c.) 6, Fungi (mushrooms, puff-balls, mould, wheatrust, \&ic.)

Renerks. When a plant cannot be made to fall ander the order or section which its characters seen to indicate, it should be tried through the whole class or whole order, as though no sabdivisions were made. 


\section{NATURAL, ORDERS.}

Plants of the same Natural Order agree in habit, and mostly in me. dicinal properties. When they differ in these properties, the diffurcnce is indicated by the odour.

The Natural Orders of Linneus are retained vn accnunt of tha books in use which refer to them. Jussieu has improved upon Linnels great ly. Medical students ought to arrange their plants according to Jussieu in the herbarium.

Students should be told, that many plants may possess the qualities of the orders to which they belong, though in a very feeble and scarceis perceptible degree.

\section{NATURAL ORDERS OF LINNEUS.}

1. Palrs. Palms and their relatives; as Cocoanut, Frog's Lit. Larinaceous diet.

2. PIPERIte. Pepper and its relatives. In crowded spikes; a Indian turnip, Sweet-flag. Tonics and stomachics.

3. Calamarzas. Reed-like grasses, with culms without joirts; as Cat-tail, St:dge. Coarse caltle foduler.

4. Gramina. The proper grasses with jointed culms; as Wheat Rye, Oats, Timothy-grass, Indian corn. Farinaceous diet, and cattle fodder.

5. Tripetalonde.s. Corol three-petalled, or calyx three-leaved; as Water plantain, Rush-grass, Arrow-head. T'onics, and rough cattle fodder.

6. Ensat E. Liliaceous plants with sword form leaves; as Iris, Blue. cyed grass, Virginian spider-wort. Antiscorbutics and tonics.

7. OrCindE. With flesly roots, stamens on the pistils, polleu glutinous, flowers of singular structure, with the germ inferior; as Ladies' slipper, Arethusa. Farinaceous diet, and stomachics.

8. Scitaminez. Liliaceous corols, stems herbaceous, leaves broad, germ blunt-angular; as Ginger, Turmeric. Warming stomachics.

9. Spathaces. Liliaceous plants with spathes; as Daffodil, Ouion, Snow-drop. Secernant stimulants."

10. Coronarıe. Liliaceous plants vithout spathes; ns Lily, Tulip, Star-grass. The nauseous scented and bitter are anliscoroulic anc. cathartic; the others emolient.

11. SARMENTACEA. Liliaceous corols with very tweak stems; as Smilax, Asparagus, Bell-wort. Tonics and secernanl stimulants.

12. Oleracke, or Holeraces. Having flowers destitute of beauty, at least of gay colouring ; as Beet, Blight, Pig-weed, Dock, Pepperage. If nauseous, cathartic; others, mild slimulants and nutrien. ties.t

13. Socculents. Plants with very thick succulent leaves; az Prickly·pear, Houseleek, Purslain. Antiscorbutic and emolient.

14. Gruinales. Corols with five petals, capsules beaked; as Flas, Wood-sorrel, Crane bill. Tonics and refrigerants.

* Which promote the secretion of perspirable matter, \&c. \&c.

$\dagger$ Nutrientics of Darwin, which serve as nutriment merely, without produc ing any extraordinary effects. 
15. INexDATA. Crowing under water, and having fowers destitute wî beauty; as Hippuris, Pond-weed. Astringents.

16. Calyciflor.玉. Plants without eorols, with the stamens on the ralyx; as Poet's eassia, Seed luekthorn. Astringents and rcfrige. rants.

17. Caryenatrex. Calys on the germ, or growing to it, fowers beantiful; as Willow-herb, Ludwigia, Cinotlera. Tonics.

13. Biconses. Anthers witl two strait liorns; as Whortleberry: Spicy and Bitter Wintergreen, Laurel. Aslringlnls.

19. Hssprines. Siveet-scented, leaves cevergreen; as Myrtle, Cloves, Mock orauge. Astringent and stomachic.

20. RotACEA: Corols wheel-forn; as St. John's wort. Tonics.

21. Precis. Plants with early spring flowers of an elegant speciou: appearance; as Primrose. Astringents.

22. Cakyopirlise. Plants with caryopliyllous corols; as Piuk, Cockle. Astringents and secernunt stimulunts.

23. Trimlate. Flowers with three stigmas, capsules inflated and winged, and generally three-seeded, with distinct lilums; as Nasturtion, Horse-chesnut. Tonics and mutrientics.

24. Cormst.s. Corols spurred or anomalous; as Fumitory, Touch. me-not. Narcolic and antiscorbutic.

25 Putanis. Plants which bear shell.fruit; as Caper-bush. Detergent and antiscorbutic.

26. Mlustisilique. Having several pod-form capsules to each flower; as Culumbine, Larkspur, Rue, American cowslip. Cathurtir, narcotic and caustic.

27. Rıdinde. Plants with eaducous ealyres, and eapsules or siliques; as Poppy, Blood-root, Celandine. Anodyne and artiscorbutic.

28. I, crids. Corols lurid, mostly monopetalous; flowers pentandrous or didynamous, with capsules; as Tobacco, Thom-apple, Nighlitshade, Fosglove. Nurcotic and anliscorbutic.

29. CAMPANACEA. IJaving bell-form corols, or those whose general aspect is somewluat bell-form; as Morniug-glory, Bell-flower, Violet, Cardinal-flower. Cathartics and secernant stimulants.

30. Contorta. Corols twisted or contorted; as Mlilk-weed, Pcriwinkle, Clooke-dog. Crthartics and antiscorbutics.

31. VEPRECUR. Having monophyllous ealyxes, coloured like co. rols; as Leatler wood, Thesium. Antiscorbutic and cmetic.

32. Papilionace E. Having papilionaceous flowers; as Peas, Beans. I.ocust-tree, Clover. Emolient, diuretir, nutrientic.

33. HonENTACEIE. Havirg legumes or loinents, but not perfer papilionaceous flowers with united filaments; as Cassia, Sensitive plant. Emolient, astringent, cathortic.

34. Cucurbitaces. Fruit pumpkin-like, antiers mostly united; as Melons, Cucumbers, Passion-flower. Catharlic and refrigerant.

35. Senticosw. Prickly or lıairy, with polypetalous corols, sut a number of seeds either naked or sliglitly covered; as Rose, Raspluerry, Strawberry. Astringent and refrigerant.

36. PowaCEE. Having many stamens on the ealyx, and drupace. nus or pomaceous fruit ; as Pear: Currant, Cherry, Peacl. Refrigerants.

37. CoLUMNIFERA. Stamens united in the form of a column: as Iollyhoek, Mallows, Cotton. Emolient.

38. Tricocce. Having three-celled capsules; as Castor-oil plant, Epurge, Bos. Catharlic. 
39. Sillevosx. Having silique pods; as Cabbage, Jluslard, Shepherd's purse. Diuretic, antiscorbutic, nutrientic.

40. Personate. Having personate corols; as Snapdragon, Monkey-fower. 'Deobstruents and cathartics.

41. Asperifolie. Corols monopetalous, with five stamens, seedfive, naked, leaves rough ; as Comfrey, Stone-seed, (lithospertaum.) . Istringents and deobstruents.

42. Venticillata. Having laknte flowers; as Sage, Thyme, Catmint, Vother-wort. Stomachics and astringcnts.

43. Dumos.z. Bushy pithy plants with small flowers, petals in four or tive divisions; as Sumach, Elder, Holly. Tonic and cathartic.

44. Seprarie. Having mostly tubular divided corols, with few stamens-lieing ornameutal shrubs ; as Jilac, Jasınise. Astringents.

4ó. Uneeltates. Flowers in umbels, with five-petalled corols, stainens five, styles two, and two nakeil seeds; as Feniel, Dill, Carrot, Poison hemlock. Stomachic and nurcotic.

46. Hederacese. Corols five-cleft, stamens five to ten, fruit berry-like on a compound raceme; as Grape, Ginseng, Spikenard. Toinics and refrigerants.

47. Stcliate. Corols four.cleft, stamens four, seeds two, naked, leaves mostly whorled; as Bed-straw, Dog-wood, Venus' pride. Tunics and Deobstruents.

48. AgGregate. Having aggregate fowers; as Button-bush, Marsh rosenary. Tonics and s+cernanil stimulants.

49. Composits. All the compound llowers; as Sun-flower, Bone. net, Tansey, Thistie. Tonics and srcernanl stimulants.

50. Amevtaces. Bearing pendant aments; as Hazle, Oak, Clicsnut, Willow. Astringents.

51. Confiera. Bearng strobiles; as Pine, Juniper, Cedar. Tonics and stomuchics.

52. Coadunats. Suveral berry-likg pericarps, which are adnate; as Tulip-tree, IIagnolia. Tonics.

53. Scabridx. Leaves rough, flowers destitute of beauty ; as Netthe, Hemp. Hop, Elm. Astringents.

54. Miscellane.x. Plants not arranged by any particular eharacter; as Pund-lily, Puke-weed, Anturanth. Their qualitios are various; but see Jussicu's orde rs.

55. Filices. All furns; as Bralses, Mrillen-hair. Secernant stimulants.

56. Musc1, All mosses; as Pulytrichum. Cathartics and secernant slimulonts.

5\%. Ar.G. A. All liverworts, licliens, and sea-rveeds; as Jungermennia, Fineus, Usuea. Tonics.

55. Funal. All funguses; as Mushroom, Tuad-stool, Puff-ball, "'ouch-wood, JIould. Tonics and calleartics. 


\section{NATURAL ORDERS OF JUSSIEU.}

The Natural system of Jirsieu is founded upon characters greatly re. sembling, in principle, those which Limneus considers as artificial. But notwithstanding this adtificial appearance, the application of these characters forms the hasis of a system, which is truly natural.

Plants are distributed into grand divisions by their sceds, 3 Those plants whose seeds consist chiefly of two fleshy parts, called Cotyledons, as the pea, bean, \&cc. cunstitute the largest subdivision; culled the Dicotyledonous division. Those, whose seeds consist chiefly of a single cotyledon, as wheat, barley, Indian corn, kc. constitute a smaller subdivision, called the Honocotyledonons division Thuse, whose seeds contain no fleshy mass; having rothing analogous to the cotyledon, excepting a thin membrane in some cases, as the mosses, licliens, fingy, sc. constitute the smallest subdivision, called the $A c o$. tyledonous division.

These graud divisions are subdivided into orders, by a general enu. meration of natnial characters. The Acotyledonous division is lirectIy distributed into sis natural orders. But the other two divisions are first distributed into classes, and these classes into ninety-four natural orders, making in the whole one hundred orders.

The two cotyledonous divisions are distributed into classes by the relative position of the germ and the orgaus of the flower nearest to it. The threc positions of these organs are, on the top of the germ, around the germ, and below the germ. The Monvcoty!efionous division is divided intu three classes. One class bas the stamens nut the top of the germ, another has them around the germ, and the third has them below the germ The Dicotyledonous division has nine classes construct. ed upon the same general plan. The first three classes contain plants without corols, the second hree classes contain plants with monopetalous corols, the third three classes contain plants with polypetalous corols. This grand division contains eleven classes however One of these extra numbers is constituted by subdividing one of the rine classes, by the urion and separation of anthers And the other extra nunber, (the eleventh class) is chiefly founded on the diclinious character of the plants ombraced in it. It is, however, the most defectivo class.

\section{First Difisior.}

\section{ACOTYLEDONS,}

OR, PLANTS WITH GONGTLOES SEEDS.

\section{Order I. Fungi.}

Plants of this order are never strictly aquatic, thongh some of them grow in water and in hoth damp and dry places indifferently. They nevel exhibit the verdure of green herbage : but are generally corky, Aeshy, or mould-like. They vary much in form and colour: being spherical, hemispheric, columnar, clavate, filamentous, lamellar, capsular, pulverulent; white, yellow, red, black, greenish, \&c. The fruit of some is exterual, of others internal, of others its place can hardly be demorstrated. No plant of this order gives off osygen gas by the action of light. 
Generic names. Sphaeria, Stilbospora, JIysterium, Xyloma, Nac :uaspora, Tubercularia, Sclerotium, Tuber, Geastrum, Lovista, Iul, stuma, Lycoperdon, Scleroderma, Lycogala, Fuligo, I'hysarum, 'Trichia, Arcyria, Stemonitis, I'ubulina, Mucor, Onygena, Aecidium, UreIo, Puccinia, Trichoderma, Conoplea, Cyathus. Phallus, Armanita, Agaricus, Meruliıs, Dedalius, Buletus, Sistotrema, Hydnum, Thelephora, Merisına, Clavaria, Geoglossuni, Spathularia, Leotia, Helvella, Morchella, Tremella, Peziza, Aegerita, Isaria, Monila, Dematium, Lrineum, Racolium, Himantia, Mesenterica.

Propertics. Tonics if dry or corky, calhartics and narcotics if juicy. In alkaline juice cxudes from some.

\section{Order II. Algae.}

First division. The proper algae are mostly aquatics. They are hlamentous or membranous, and nearly similar in all their parts. They absorb circulating fluids througl theirimmersed parts only, which are not transfused through other parts. They are generally green or redlish, and give off oxygen gas from the parts under water which are exposed to the sun.

Generic names. Fucus, Chordaria, Laminaria, Delesseria, Sphaerococcus, Halymenia, Ulva, Vaucheria, Hutchinsia, Caramium, Lemaגia, Conferva, Zygenema, Oscillatoria, Batrachosperınum, Rivularia, Nostoc.

Second division. The proper lichens are various in texture, form and colour. They are lenthery, woody, lamellated, leaf-like, filamentous, white, yellow, greenish, black, \&ce. Often they appear like green herbage, especially if wet. Some appear like leprous spots on stones and trees, speckled with black, white, or yellow dots. Others in greenislu or bluish patches on old feuces and walls; and others in strong light green filaments, suspended from branches of trees, which are falsely called mosses.

They absorh circulating fuids, which are transfused through every part of their substalice. Their fructification is in the form of clefts, spangles, pulfs, buttons, tubercles, hollows, cellules, globules, shields, targets, orbs, or knobs.

Generic names. Spiloma, Arthonia, Gyalecta, Lecidea, Calicium, Gyrophora, Opegrapha, Graphis, Verrucaria, Endocarpon, Porina, Pyrenula, Variolaria, Urceolaria, Lecanora, Parmelia, Borrera, Cetra. ria, Sticta, Peltidea, Nepluroma, Evernia, Cenomyce, Bacomyces, Isidium, Stereocaulon, Rlhizomorpha, Alectoria, Ramalina, Collema, Cornicularia, Usnea, Lepraria.

Properties. Tonics-sorne contain useful colouring mattcr, and soms are nulrilive.

\section{Order III. Hepalicae.}

Plants of this order have green or greenish fronds ; some resembling the fronds of lichens, others those of mosses, but more succulent and cellular. They are always monoecious or dioecious. The barren or staminate flowers contain globules, aggregated together in a kind of calyx, flled with a liquid analagous to pollen. The fertile or pictillate fowers have Eerms or capsules, either naked or surrounded with pe*isbcths, which are mostly peduucled. The seeds gencrally adbere to 
spirally twisted fures. The capsules are always 4.celled and destitute of lids; which characters distinguish this order from the next.

Generic names. Riccia, Anthoceros, Marchantia, Jungermannia.

Properties. Tonics and refrigerants.

\section{Order IV. Musci.}

Plants of this order are monoecious, disecious or perfect. The nowers are lateral or terminal, mostly elevated on peduncles. In early flowers Sprengel says, that by the help of a magnifying glass, "organe " may be distinctly seen, which consist partly in oblong bud-like gem. "mae, supposed formerly to be anthers; and partly in an aggregation " of pistils, intermixed with succulent filaments."

Their capsules are always 1-celled, and open at top by operc!li, or lids. Over the lids, calyptres are generally placed. Under the lids and surrounding the moutlis may be seen a kind of filamentous or denticulate fringe or edging, called teeth.

The seeds are very numerous, resembling fine dust adhering to the inner surfaces of the capsules. The lierbage is green and perennial; the leaves are minute and generally imbricated. Mosses flourish mosi in damp shady situations; and mostly flower early in the spring or late in autumn.

Generic names. Sphagnum, Phascum, Gymnostomum, Schistidium, Anoectangium, Tetraphis, Grimmia, Weissia, Trematodon, Dicranum, Campylopus, Racomitrum, 'Trichostomum, Barbula, Syntrichia, Didymodon, Splachuum, Ornithotrichum, Ulota, Bartramia, Bryum, Arrhenopternm, Mnium, Timınia, Diplocomium, Meesia, Diphyscium, Buxbaumia, Funaria, Pterigynaudrum, Lasia, Leucodon, Neckera, Cryphaea, Pilotrichum, Climacium, Leskia, Pterigophyllum, Hypnum, Nontinalis, Fissidens, Polytrichum, Catliarinaea.

Properties. Moslly secernant stimulants; some few are cathartic.

\section{Order $V$. Filices.*}

Plants of this order are herbaceous and take root in the earth; but bear numerous minute dust-like seeds, like other cryptogamous plants.

First division. The plerous fcrns bear spherical or reniform 1-celled capsules on the back of winged fronds or on what appears like leaves metamurphosed in to fruit-bearing spikes. The leaves are sub-radical, with alternate leafets, or alternate divisions or indendations. The are mostly coiled, or more or less rolled in at their tips, when they first spring from the earth.

Generic names. Acrostichum, Polypodium, Onoclea, Blechnum, Pteris, Asplenium, Scolopendrium, Woodivardia, Adiantum, Aspidium, Athyrium, Dicksonia, Woodsia, Cheilanthes, Schizaea, Osmunde, Lycopodium, Botrychiuı, Ophioglossum.

Second division. The Apleres bears fruit on spikes, in the axils of leaves, or in the substance of the frond, having no proper winged frond. They are either very leafy or totally leafless. Neither the leaves nor any other parts of apterous ferns are ever coiled.

* De Lamarck and De Candolle place this order, and the next, among tie Monocotyledons. 
Gcneric names. Lycopodium, Equisetum, Isoetes.

Properties. Secernant stimulants.

\section{Order VI. Naiades."}

Plants of this order are tender aquatics, with few axillary flowe:3 containing few minute stameus.

Generic names. Caulinia, Chara, Najas, Saururus, Podostemum Lemna.

Properties. Astringent.

\section{Second Division.}

\section{MONOCOTYLEDONS.}

OR, PLANTS WITH 1-LOBED SELDS.

CLASS FIRST. Stamens below the pistil.

Order VII. Aroideae.

Plants of this order all bear monoecious flowers, which are sessile on a spadix, and destitute of perianth calyses. Stamens and pistils are intermixed and stand on the spadix. Fruit a roundish berry. They are almost stemless, with sub-radical leaves; and support the flowers on scapes or scape-like stalks.

Generic names. Ictodes, Calla, Zostera, Arum, Orontium.

Properties. Warming stomachics; if nauseous, antispasmodirs.

\section{Order VIrI. Typhae.}

Plants of this order bear monoecious flowers with 3-leaved perianths. Stamens 3 and styles one. Fruit 1-seeded, seed fleshy or ferinaceous. They are always aquatics, stems jointless, and leaves some what sheathing.

Genteric names. Typha, Sparganium.

Properties. Weali tonics.

\section{Order IX. Cypervideae.}

Flowers glumaceous, in spikez or spikelets, glumes 1-valved. The fowers have no proper perianth calyxes ; stamens 3 , style 1 , with two or three stigmas; seeds single, farinaceous, without pericarp. Plants grassy, perennial, of a coarse texture ; culm triangular or cylindric ; leaves with closed sheaths or destitute of sheaths.

Generic names. Kyllingia, Sclioenus, Rhy nclıospora, Cyperus, $\mathrm{Ma}$ riscus, Dulichiam, Scripus, Erioplıoram, Tricophorum, Fuirena, Limuetis, Cares, Scleria.

Properties. Tonics. Used for coarse caltle folder.

\section{Order X. Gramineae.}

Flowers glumaceous, generally in spikes or spikelets, but sometimes solitary. Outer glumes generally 2-valved, which serve as calyses to * De Lamarck and De Candolle say that this order is artiticial and ought to
be abolished. 
" pikelets, or to single flowers when solitary. Stamens 3 ; stigmas 2 , plumose or capillary. Seeds single, farinaceous, without pericarps. Culms cylindric, jointed; leaves alternate, with shcaths always cleft throughout their whole extent, on the side opposite to the direction of the leaf.

Generic names. Cinna, Anthoxanthum, Cenchrus, Oryzopsis, Pani. cum, Digitaria, Cynodon, Paspalum, Arıstida, Stipa, Alopecurus, Phalaris, Crypsis, Hordeum, Milium, Agrostis, Saccharum, Mublenbergia, Leersia, Trichodium, Phleum, Aira, Uralepsis, Elymus, Melica, Eleusine, Secale, Triticum, Lolium, Alheropogon, Uniola, Briza, Sorghum, 1)actylis, l'oa, IVindsoria, Festuca, Bromus, Avena, Danthonia, Arunlo, Andropogon, Holcus, Oryza, Zea, Tripsacum, Coix, Zizania, Hicrochloa.

Properties. Fceblc tonics. The herbage furnishes the best of cattle fodder; and the largest seeds are used for farinaceous diet.

CIAAS SECOND. Stamens surrounding the pistil, and standing on the calyx or corol. Sometimes they are merely attached at the basc.

\section{Order XI. Palmae.}

He have no plants of this order in the Northern States. The coco. \&nut, palm, and several other tropical plants belong to this order.

l'roperties. Weak tonics, and yicld farinaccous dict.

\section{Order XII. Asparagi.}

Flowers with petaloid perianths, generally 6-parted or 6-cleft. Stawiens adhering to the same base with the corol or calyx. Berry 3 or 4. celled, 1 to 3 -seeded. Leares often alternate, rarely whorled, neve sheathing.

Gencric names. Asparagus, Convallaria, Dracaena, Gyromia, Smi. !as, Trilliun.

Propertics. Mild tonics and sccernant stimulants.

\section{Order XIII. Junci.}

Plants of this order generally bear fowers with small spathes, of spatlie-like bracts, and free $6 \cdot$ parted periantlis.

First division. The proper. Junci resemble the Gyperoideae in babit ; luaving sheathing leaves and glumaceous spathes or bracts. The flowf:rs are ill panicles or coryubs ; stamens 3 or 6 , and each flower lias tut a single germ.

Generic names. Juncus, Xyris, Acorus, Tradescantia, Commelina, Jelonias, Xerophyllum, Ve ratrum, Tofieldia.*

Sccond division. The Alismaccae are all aquatics, and each ofower contains more than one germ.

Generic names. Alisma, Sagittaria, Triglochin, Scheuchzeria, Eriocaulon, Potamogeton, Zanichellia.

Properties. Generally secernant stimulants. The sweet-scented, are warming stomachics, and the nauseous are astiscorbutics.

* The two last are placed in a distinct order by De Lamarck and De Can3o!!?. 


\section{Order XIV. Liliaceae.}

Plants of this order have no perianths. They have ti-petalled coruls of the litiaceous form. Stamens 6, standing agaiust the divisions of the corol and often attached to it. Style 1, stigmas 3, or 3-lobed. Germs free. Capsules 3-celled, 3-valved, with transverse partitions; seeds flat. Leaves generally with simple nerves.

Generic names. Lilium, Tulipa, Fritillaria, Erythronium, Uvularia, Streptopus.

Propertics. Emollicnt and weak secernant stimulants.

\section{Order $\mathrm{X} V$. B.umeliae.}

We have no plants of this order, excepting rare exotics, growing in the Northern States. The pine apple (Bromelia ananas) belongs here.

Properties. Refrigerants.

\section{Order XVI. Asphodeli.}

No perianths, but some have spathes. Corols 6-parted or 6-cleft. Stamens 6 , standing against the divisions of the corol and attached to it. Germs free; seids round or angled.

Generic names. Asphodelus, Hemerocallis, Ornithogalum, Allium, Aletris, Narthecium, Hyacinthus.

Properties. Expectorants and demulcents. The strong-scented are sc. cernant stimulants, and the bitter are tonic and cathartic.

\section{Order XVII. Narcissi.}

No perianths, but most have spathes. Corols 6-parted or 6-petalled Stamens 6, standing against the divisions of the corol and attached to it. Germ attached to the corol, and generally supporting it.

Generic names. Narcissus, Amaryllis, Galanthus, Polyanthes, Agave, Hypuxis, Leptanthus, Pontederia, Heteranthera.

Properties. Weak tonics and cmollients.

\section{Order XVIII. Irides.}

Corol 6-cleft or 6-parted: stamens 3: style 1, with 1 or 3 stigrans germ attached to the corol. Leaves ensi-form or linear. Roots bulth. ous or tuberous.

Generic names. Iris, Ixia, Crocus, Dilatris, Sisyrinchium.

Properties. Antiscorbutics and tonics.

CLASS THIRD. Stamens standing on the pistil.

\section{Order XIX. Musae.}

We have no plants of this order in the Northern States. The breav tree (Artocarpus incisa) belongs here.

Properties. Tonics.

\section{Order XX. Cunnac.} Lere.

No plants of this order in our district. Ginger (Amomum) is place! Properties. Warming stomachics. 


\section{Order XXI. Orchideae.}

Plants of this order have superior, 5-petalled coruls, 3 external and 2 internal. There is also in each corol a petal-like organ, called the lip, various in form and direction. Anthers always 1 or 2 , and from 1 to 4-celled, sessile upon the side or apex of the style. The pollen is easily r'emoved from the cells in agglutinated masses. Styles simple, with viscous stigmas of various forms and positions. Capsules 1-celled, 3-valved, 3-keeled. Seeds numerous, dust-like. Leaves entire, and generally nerved and clasping. Flowers more or less spiked and bracted.

Generic names. Orchis, Goodyera, Neottia, Listera, Pogonia, Triplıora, Cymbidium, Arethusa, Tipularia, Malaxis, Microstylus, Corallorhiza, Cypripedium.

Properties. Emollients, and the roots of some are stomachic. Dioscorides, Galen, and Pliny, speak of the roots as affording excellent farinaceous diet, and as of great use in discussing swellings and cleansing ulcers.

\section{Order XXII. IIydrocharides.}

Plants of this order are all aquatics. Germs simple; stigmas 3 to 6 , bifid. Capsules 1 or 6 -celled, many seeded. Rather an artificial order.

Generic names. Proserpinaca, Floerkea, Vallisnerio.

Properties. Weali tonics.

Thiro Division.

DICOTYLEDONS,

OR, PLANTS WITH 2-LOBED SEEDS.

CLASS FIRST, Section I. Flowers apetalous. Stamens standing on the germ.

Order XXIII. Aristolochiae.

Perianth 1-leaved adhering to the germ. Stamens numerous, (6 or 12) definite, attached to the germ. Style short, stigma divided. Capsule many-celled (generally 6) many-seeded.

Gereric rames. Asarum, Aristolochia.

Properties. Warming stomachics and active tonics. Galen set a high value on the tunic powers of this order of plants.

CLASS SECOND. Stamens surrounding the germ, being attached to the calyx.

\section{Order XXIV. Aeleagni.}

Calyx adheres to the germ, monophyllous, tubular, generally leafy outside and corol-like within. Stamens stand towards the top of the calyx, and are equal to the number of its division or double that number. Fruit 1-seeded.

Generic names. Thesium, Nyssa, Hippophae.

Properlies. Weak tonics. 


\section{Order XXV. Thymelac.}

Calyx free, 1 -leaved, 4 or 5 -lobed, coloured. Stamens inserted to wards the upper part of the calyx, and are double the number of its di visions. Fruit l-seeded. Stems woody; leaves simple, entire and alternate.

Generic names. Dirca, Dapline.

Iroperties. Mild emetics and antiscorbutics.

\section{Order XXVI. Prolae.}

No plants of this order grow in our district. The silver-tree (Protea) is placed here.

Properties. Weak tonics.

Order XXVII. Lauri.

Calyx free, monophyllous, permanent, 4 to 6 cleft, or 6-parted Stamens inserted at the bottom of the divisions of the calyx, some times 6 in a single row, sometimes 12 in two rows, generally varying in number; anthers adnate to the filaments, dehiscent from their buse: to their apexes. Germ 1, style 1, stigma simple, or divided. Drupe or berry 1-celled, 1-seeded. Stems woody, leaves alternate.

Generic name. Laurus.

Properties. Warming stomachics and active sccernant stimulants.

\section{Order XXVIII. Polygoneae.}

Calyx free, monophyllous, divided, nften coloured. Stamens insert ed on the bottom of the calyx; anthers 2-celled and 4-grooved, lateralJy dehiscent into a double chiuk. Germ 1, styles or sessile stigmas several; seed single, farinaceous, naked, with the corcle inside.

aeneric namcs. Polygonum, Rumex, Rheum.

Properlies. Mild cathartics and demulcents. The strong-scentch, are antiscorbutic and discussiont.

\section{Order XXIX. Alriplices.}

Calys free, monophyllous, parted. Stamens inserted on the bottom of the calyx, and equalling the number of its divisions. Germ 1 , style 1 or several. Seed often farinaceous, with corcles outside of it. Leaves alternate, simple, destitute of stipules or sheathes. Flowery small, greenish, and of a dull appearance.

Generic names. Salicornia, Blitum, Salsola, Chenopodium, Reta, Atriplex, Spinacia, Acnida, Phytolacca.

Properties. The strong-scented are active cathartics. The others are mildly aperient.

CLASS THIRD. Stamens standing below the germ.

\section{Order XXX. Amaranihi.}

Calyx free, permanent, divided, often coloured. Stamens 3 or 5 Germ 1, capsule 1-celled. Seed farinaceous. Flowers small.

Generic names. Amaranthus, Gomphrena.

Properties. Secernant stimulants and weak tonics. 


\section{Order XXXI. Plantargines.}

Calys double, outer one 4-partcd, inner one tubular. (Rather the outcr is a proper calyx, aud the inner a dull membranaceous corol.) Stamens 4 , adhcring to the inner calyx, exsert. Germ simplc, style 1 . Capsule opening transversely. 2 to 4-cellcd Seed corneous. Flow. ers in spikes. Leaves ncrved and generally radical.

Generic name. Plantago.

Properties. Emollients.

\section{Order XXXII. Niyclagines.}

Involugre perianth-like, monophyllous; periantls monoplyyllous, coloured, permanent, contracted above the germ so as to appear altogether like a corol standing on the germ. Stamens attached to the gland-like base of the inner calyx, (corol?) which encloses the germ Style 1, capitate. Secd farinaceous.

Generic name. Mirabilis.

Properties. Emetics and cathartics.

\section{Order XXXIII. Plumbagines.}

Caly $x$ doublc, permanent; outer one monophyllous, tubular; inner one (rather the corol) coloured, 1 or many-petalled. Stamens 5, adlicring to the inner calyx (corol?) Germ simple, frce, styles many, or one with many stigmas. Capsule 1-seeded. Sccd farinaceous.*

Generic name. Statice.

Propertics. Calhartic and tonic.

CLASS FOURTH. SEction II. Flowers monopetalous. Corols inserted below the germs.

\section{Order XXXIV. Lysimachiae.}

Calyx monophyllous, permanent, 4 or 5-lobed. Corol with the limb divided, and bearing the stamens opposite, and equal in number, to the divisions. Germ free, stylc 1, stigma simple. Capsule 1-celled, many-seeded, seeds attached to a free columella, the corcle strait and within the fleshy seed. Leaves simple.

Generic names. Lysimachia, Anagallis, Trientalis, Primula, Dodecatheon, Samolus, Hottonia, Buchnera.

Properlies. Tonics and weak secernant stimulants.

\section{Ordcr XXXV. Pcdiculares.}

Calys divided, permanent, often tubular. Corol irregular, often riagent. Stamens 2 or 4 , inserted on, or attached to, the corol; when 4 , two are shorter. Germ free, style simple; capsule 2-valved. Seed with semitcrete cotyledons. Flowers bracted.

Gcneric names. Polygala, Veronica, Callistachia, Bartsia, Rhinantaus, Obolaria, Euphrasia, Melampyrum, Erinus, Pediculares, Oro-

* Here in the three last orders we see, that the adrocates for the natural arrangement are compelled to force a corol to become a calyx. But the Linnean artificial system will guide the student to the true genus, thence to the natural order, and thus secure to bim its advantages. 
banche, Epiphegus. [The two last have been placell in a gub-order, and distinguished by their capsules being 1-celled, and hearing sceds on a longitudinal nerve.]

Properties. Deobstruents, catharlics and mild tonics. Ancient authors, as Dioscorides, Pliny and nthers, valued most plants of this or. ler for their efficacy in bealing wounds, by exterual application.

\section{Order XXXVI. Acanthi.}

Caly $x$ divided, permanent, often bracted. Corol irregular. Sta. suens 2 or 4 . Gerin free, style 1, stigma 2-lobed. Capsule 2-celled. Seed with foliaceous cotyledons.

Generic names. Justicia, Ruellia.

Propertics. Emollients.

\section{Order XXXVII. Jesmineae.}

Caly tubular. Corol tubular, except in Frasinus. Stamens 2, excepting Fraxinus, inserted in, or attached to, the corol. Seed with a flat corcle. Stems woody. inus.

Generic namcs. Jasminum, Ligustrum, Syringa, Chionanthes, Frax-

Properties. Mild tonics and secernant stimulants. Petals of the Sy. ring a contain prussic acid.

\section{Order $\mathrm{XXXVIIT.} \mathrm{Vitices.}$}

Calys tubular. Corol tubular. Stamens 4,2 of them shorterrarely 2 or 6 . Germ free, style 1, stigma simple or 2 -loded. Corcle of the seed strait. Leaves opposite.

Generic namc. Verbena.

Propertics. Deobstruents and secernant stimulants. Parkinson, and the older authors, considered them as antidotes to the poison of serpents, \&c.; but the moderns do not ascribe to them any very active powers.

\section{Order XXXIX. Labialae.}

Calyx tubular, 5-cleft or 2-lipped. Corol tubular, irregular, often 2-lipped, the upper lip mostly 2-cleft, and the lower one 3-cleft. Stamens sometimes 2 , mostly 4 , with two of them shorter; they are always inserted under the upper lip of the corol. Germ free, 4-lobed; each lobe becoming a naked seed at the bottom of the calyx, with a strait corcle and flat cotyledons. Style 1, stigna 2-cleft. Stems generally, or perhaps always, 4-sided; leaves onposite. Flowers oftea whorled, and sometimes spiked.

Generic names. Lycopus, Monarda, Rosmarinus, Salvia, Collinsonia, Teucrium, Isanthus, Lavandula, Lamium, Pycnanthemum, Nepeta, Hyssopus, Mentha, Stachys, Galeopsis, Satureji, Leonurus, Marrabium, Ballota, Cunila, Hedeoma, Glechoma, Melissa, Trichostema, Ocymum, Scutellaria, Origanum, Thymus, Clinopodium, Prunella,
Phryma, Molucella.

Properties. Very activosecernant stimulants, embracing all the most valuable sudorifics. The sweet-scented are warming stomachics, and the citter ones are lonics. Ancient pbysiciaus seem to bare drawn a 
large proportion of their vegetable materia necliea from this order. 'They established the medicinal virtues of these plants very nearly as they are now understood. To thcse virtues ascribed to them by moderı pliysicians, they added, however, that they are efficieut as vermi. fuges, and in the cure of epilepsy, bemorrhagy, bites of serpents, and stings of scorpions.

Parkinson, who wrote almost two centures ago, cites as authorities for the above, the trials and practice of Theophrastus, Dioscorides, Galeu and Pliny amoug the ancients; and Matthiolus, Clusius, Camerarius, Agrippa, Dodoneus, and many others anıung the oldest of the moderus.

\section{Order XL. Scrophularia.}

Caly $x$ divided, often permanent. Corol irregular, limb divided. Stamens rarely 2 , mostly 4 , with two of them shorter, inserted on the corol. Germ tree, style 1, stigma simple or 2 -lobed. Capsule 1 or 2. celled, 2-valved, valves concave. Seeds nunerons, atfixed to the middlo of the partition, with a strait corcle and semi-cylindric cotyledous. Flowers bracted.

Generic names. Utricularia, Gratiola, Linderuia, Hewianthus, Erinus, Dracocephalum, Schwalbea, Limosella, Zapauia, Scrophularia, Antirrliuum, Cullinsia, Gerardıa, Digitalis, Mimulus.

Properties. Deobstruents, absorients, and mild narcotics. Ancient physicians applied them to the wounds exterually. Parkinsou used the Digitalis in the epilepsy two centuries ago with great success.

\section{Order XLI. Solaneae.}

Calyx 5-cleft or 5-parted, eften permanent Corol regular, 5-cleft, mostly of a lurid hue Stamens 5 , atlached to the base of the corol, and alterualing with its lobes. Germ tree, style 1, stigma simple or sub-cleft. Fruit 2-celled, many-seeded, either a 2-valved capsule or a berry. Seeds with spiral corcles and semi-terete cotyledons. Leaves alternate.

lieneric names. Lycium, Datura, Nicotiana, Verbascum, Atropa, Phacelia, Hyoscyamus, Solanum, thysalis, Capsicnm.

Properties. Calhartic, discussient, emetic, and antiscorbutic. The nat. seous-scented are very strong narcotics; pungent scentc arc warming and deoustruent. Several centuries ago they were much used, exter nally and internally, in gouts and rheumatisms.

\section{Order XLII. Boragineac.}

Calyx 5-lobed, f,ermanent. Corol 5-lobed, mostly regular, having a horder and a tube, with the upper entrance of the tube, called the meus 5 , attached to the tube of the corol. Germ free, with 4 lobes,
which become 4 naked seeds; style simple, permanent, springing up from among the lobes of the germ; stigna entire, or 2-lobed. Seeds attached laterally to the style; curcle strait, cotyledous foliaceous. Leaves alternate, mostly scabrous.

Generic names. Pulmonaria, Cerinthe, Litlospermum, Cynoglos. sum, Batschia, Anchusa, Myosotis, Heliotropium, Onosmodium, Bo. rago, Symphitum, Echium, Hydrophyllum.

Propertics. Astringent and vulnerary. 


\section{Order XLIII. Convoluuli.}

Calyx 5-lobed, permanent. Corol regular, 5-lobed. Stanens 5, al tached to the corol, and alternating with its divisions. Germ free, hav ing oue or many styles. Capsule generally 3-valved arid 3-celled sometimes 2 to 4 -celled and 2 to 4-valved; columella central, 3-cor. inered. Seed bony, cotyledons folded together. Leaves alternate Stem often twining or climbing.

Generic names. Convolvulus, Dianensia, Ipomaea, Pyxidanthera, Euscnta.

Properties. Cathartics, mostly very mild.

\section{Order XLIV. Polemonia.}

Calyx divided. Corol regular, 5-lobed. Stamens 5, attached to the middle of the tube of the corol, alternating with the divisions. Germ fice, style simple, stigmas generally 3 , or 3-cleft. Capsule surJ'ounded with the permanent calys, 3-celled, 3-valved, many-seeded ; columella central, 3-cornered. Seed with a stiait corcle, and oval foliaceous cotyledons. Leaves opposite.

Grneric namies. Plilox, Polemonium.

Propertics. Fecble tonics.

\section{Order XLV. Bignoniac.}

Calyx divided. Corol irregular, ringent aud inflated. Stamens rarely 2 , all others 4 , with two of them shorter; an odd filament-like organ accompanies them. Capsule 2 or 4 -celled, 2 -valved. lone.

Generic names. Bignonia, Catalpa, Martynia, l'entstemon, Che.

Propertics. Mild narcotics, deobstruents and cathartics.

\section{Order XLVI. Gentiana.}

Calyx monophyllous, divideci, permanent. Corol regular, often marcessent ; limb equally divided into a number of parts equal to shose of the calyx and of the stamens, which are mostly 5 . Stamens. attachea to the corol. Germ free, style 1 or 2 , stigmas simple or 2 . lobed. Capsule 1 or 2-celled, 2-valved, many-seeded; seeds inserted on the infexed margins of the valves. Herbage glabrous, bitter,
leaves opposite.

Gencric names. Gentiana, Spigelia, Swertia, Frasera, Sabbatia Menyanthes, Villarsia.

Propcrtics. Tonics and mild cathartics. The Spigelia is considered as a vermituge. Dioscorides, Galen, and other ancient physicians, considered the Gentiana as a vermifuge and an antidote to poison.

\section{Order XLVII. Apocyncae.}

Calyx 5-lobed. Corol 5-Inbed, regular; ofien furnished with 5 nectariferous appendages. Stamens 5 , inserted in the bottom of the corol, or suspended from the angles of the stigma." Germs frec,

* The celebrated Robert Brown says, that in the young state the anthers of the Asclepias syriacus are uot attached to the stiginas. The reader is re. ulested to examine the anthers at all stages from the first swclling of the ilower. 
double, style 1 or none, stigma capitate. Follicles elongated, gener. ally in pairs, 1.celled. Seed attached to the longitudinal margins of the follicle. Herbage generally milky.

Gencric names Apocynum, Asclepias, Periploca, Vinca, Nerium, Gionolobus.

Yropertics. Active deobstruents, cathartics, antiscorbutics, and narco. ties. Ancient physicians used the Asclepias, Apocynum, \&c. as coun. ter poisons.

\section{Order XLVIII. Sapotae.}

No plants of this order grow in our district. The southern ironwood (Bumelia) is placed here.

Propertics. Fecile antispasmodics and cathartics.

CLASS FIFTH. Corols surrounding the germ, and generally inserted on the calyx.

Order XLIX. Guaiacanac.

No plants of this order grow in this district. The lignum vita ant benjamin tree are placed here.

Propertics. Very actice lonics and warming stomachics.

\section{Order L. Rhododendra.}

Calyx 4 or 5 -lobed, permanent. Corol inserted in the base of the ralyx, 4 or 5 -parted. Stamens definite, distinct. Germ free, style 1, stigma 1. Capsule 4 or 5-celled, 4 or 5 -valved. Seeds numerous, minute, corcle strait. Stems woody; leaves alternate.

Generic names. Azalia, Itea, Menziesia, Rhodora, Rhododendron, Kalmia, Ledum, Leiophyllum, Disospyros.

Properlics. Tonic. Kalmia is said to be narcotic.

\section{Order LI Ericac.}

Calyx permanent, 4 or 5-parted, often free. Corol 4 or 5-parted or vleft, inserted on the calyx or calycine gland, often rnarcescent ant? permanent. Stamens definite, distinct, inserted on the bottom of the rorol or calycine gland; anther's often 2-horned. Germ often free : style 1, stigma 1. Fruit many-celled, many-seeded ; berries or manyvalved capsules. Seeds minute, with strait corcles and fleshy cotyleledons. Stems mure or less woody ; leaves often evergreen.

Generic names. Oxycoccus, Erica, Clethra, Pyrola, Chimaphila, Arbutus, Gaultheria, Épigaea, Vaccineum, Einpetrum, Andromeda.

$S^{\prime} u^{3}$ order. Destitute of leaves or green herbage; being ivory white, yellowish white, or reddish.

Generic nancs. Pterospora, Hypopithis, Monotropa.

Properties. Valuable astringcnts. Some bear refrigerant berries. Gcrard, and other old physicians, particularly the old Germans, ap-

hud. He will find that although the anthers or masses of pollen adhere to their cases, they may be separated without lacerating the cuticle of any organ; but that they cannot be separated from the stigma in any stage without rupturing capillary fibres or vessels. Therefore the anthers certainly grow on the stigma only. $\Lambda$ maguifying porver of at least one liundred is required for this examination. 
plied plants of this order to cancerous ulcers and in bemorrbagy, two centuries ago.

\section{Order LII. Companulaceae.}

Calys adhering to the germ, limb divided. Corol inserted near the top of the calys, often marcescent. Stamens inserted on the calyx below the corol, often 5, alternating with the divisions of the corol ; anthers either distinct, united, or as thickened as to press against each other. Germ glandular above, style 1, stigma simple ur divided. Cap. sule 2 to 6-celled, many seeded, laterally dehiscent. Seeds affixed to the inner angles of the cells; corcle strait. Leaves alternate.

Generic names. Campanuly, Lobelia.

Properties. The nauseous-scented are cathartic, emetic, deobstruent and narcotic; the others arc mildly $a_{i}$ erient.

CIASS SIXTH. Corols standing on the top of the germ. Stamens with united anthers.

This class includes all plants with Com Pound Flowers, and correspond with the class Syngenesia of Linueus. The flowers have broad receptacles, flat or couvex, uaked (when the florets are removed) or chaffy, supporting many florets. Egret generally supplies the place of the calyx to each floret, and is inserted on the top of the germ. The corol is tubular or ligulate, often 5-toothed. Germ simple, style 1, stigmas generally 2 Seed single, nalsed; corcle strait, cotyledons nat.

This class is divided into three orders.

\section{Order LIII. Cichnraceae.}

Florets all ligulate and nerfect. Leaves alternate; juice in most is milky. Corols mostly yellow; rarely blue.

Gcneric names. Troximon, Apargia, Leontodon, Krigia, Prenan thes, Lactuca, Hieracium, Sonchus, Hyoseris, Cichorium.

Properties. Mild apcrients, and weak anodynes.

\section{OTder LIV. Cinarocephalac.}

Corols all tubular. Receptacles fleshy and chaffy. Stigma, above the style, articulated. Egret somewhat rigid. Leaves alternate, ofter spinose Flowers capitate.

Fieneric names. Ecliynops, Cynara, Liatris, Cnicus, Carthamue, Onepordun, Carduns, Arctium, Centanrea.

Properties. Tonics; the nauseousosecnled are catharic.

\section{Order $L V$. Corymbiferae.}

Florets tubular and ligulale, mostly radiate. Receptacle scarcely neshy. Sigma, above the style, not articulated. Inforescence often a corymb.

Generic nutmes. Sc rzonera, Picris, Tolpis, Scholymus, Vernonis, Sparganophorus, Bident, Kuhnia, Eupatorium, Mikania, Chrysocoma, Cacalia, Balsamita, Baccsaris, Conyza, Graphalium, Arteraisia, 'Ta. 
lacetum, Cirysanthemum, Zinnia, Tagetes, Bellis, Pyrethrum, Doro* aicum, Inula, Erigeron, Solidago, Senecio, Tussilago, Cineraria, As. ter, Heliopsis, Buphthalmum, Helenium, Boltonia, Matricaria, Anthe mis, Achillea, Verbesina, liudbeckia, Helianthus, Coreopsis, Silphium, Polyınia, Calendula, Iva, Elephantopos.

Propcrtics. Most valuable tonics and sccrnant stimulants. Two or three centuries ago, the pliysicians considered plants of this order as the inost sovereign remedies for flesh wounds. Parkinson makes a rlass of them, whicl he denominates VOLNERARY or IVound HERBS. bioscorides and Galen deemed them very efficacious in pulmonary complaints.

CLASS SEVENTH. Corols standing above the germs. Stamens with anthers distinct, and with filaments attached to the corol.

\section{Order LVI. Dipsaccae.}

l'lowers aggregated on a common receptacle, and surrounded by a unany-leaved involucre. Calyx double, outer one not adhering to the germ; the inner membranaceuus or pappose calyx closely contractin: around its apex. Corol inserted on the top of the inner calyx. Stamens 3 to 5, attaclied to the bottom of the tube of the corol, and al. ternating with its divisions. Seed with a strait corcle and oblong cotyledons. Leaves opposite. thus.

Generic rumes. Valeriana, Fedia, Dipsacus, Scabiosa, Cephalan.

Properties. Weak lonics.

\section{Order LVII. Rubiacca.}

Calyx adhering to the germ, 4 or 5 -lobed. Corol regular, inserted on the germ, 4 or 5 -lobed. Stamens 4 or 5 , inserted on the corol. Style 1, stigmas 2 . Seeds generally 2, corcle strait, cotyledons folia. ceous. Leaves entire, whorled.

Generic names. Galium, Rubia, Houstonia, Mitchella

Properties. Apcrients and tonics; somc abound in colouring maller.

\section{Order LVIII. Caprifolia.}

Calyx adhering to the germ, often 2-bracted at the base. Corol re. gular, 4 or 5-cleft, or 4 or 5-petalled with the petals broader at the hase. Stamens equalling the number of divisions of the corol. Style 1 or none, stigmas 1 to 3 . Berry or capsule often crowned with the pérmanent calyx. Stems mostly woody; leaves opposite, and some. times conuate

Generic names. Lonicera, Xylosteum, Symphoria, Diervilla, Vi buruum, Sambicus, Cornus, Hedera, Linnea, Triosteum.

Propertics. Tonies; and the strong-sconled are catharlic.

CLASS EIGHTH. SEction III. Hlowers polypclalous. Stamens stant. ing on the geru, and alteruating with the petals.

\section{Orler LIX. Araliae}

Calyx superior, 5-toothed, permanent. Stamens $\overline{5}$, styles 2 to $\mathscr{\xi}$. Fruit a berry Irflorescence an umbel. Leaves compound.

Generic nomes. Panax, Aralia.

Jroperlies. Valuable tonics and expectorants. 


\section{Order LX. Umuclliferue.}

Calyx attached to the germ. Petuls 5, iuserted on the germ, or on a gland eovering the top of the germ. Stamens 5, alternating with the petals Styles 2, often permanent. Fruit bipartible, beeoming 2 seeds, often ribued or grooved on their outsides, and on their joining sides, (tlie commissure.) Stems herbaceous I.eaves alternate, often compound. Inflorescenee an umbel, with the radiating peduneles often surrounded at their origin and sub-divisions with in. volueres.

Gencric names. Eryngium, Hydroeotyle, Crantzia, Daueus, Ammi, Conium, Selıum, Imperatoria, Heracleum, Pastiauaca, Ligusticum, Angelica, Sium, Erigeuin, Cicuta, Myrrbis, Uraspermum, Cliarophyl. lum, Smymiun, Thaspium, Enanthe, Carum, Apium, Anethum

Properties. Deobstrucnts and narcotics; excepting the sweet-scented, which are stomachics. In the time of Dioseorides, Fliny and Galen, (during the first a'd second centuries) the sweet-sceuted plants of this order wer: in eommou use as remedies in eases of dyspepsia, flatulency, cholic and epilepsy; and the narcotic kinds* were used as anti. dotes to poison, and as remedies in liver eomplaints, gouts aud rhentmatisms, and by way of external application in the resolution of in. flamed tumor's

\section{CLASS NINTH. Stamens inserted below the germ.}

\section{Order LXI. Ranunculaceae.}

Calyx many-leaved, or none Petals many, often indefinite. Sta. mens often indefinite in number. Germs often numerous, rarely soli. ta.y, inseried ou the receptaele, each having a single style. Secu with a minute corcle at the apex or base of a corneous albumen.

Generic nancs Zantlıorliza, Aetæa, Maerotys, Podophyllum, Delphinium, Aconitum, Aquilegia, Nigella, Hydrastis, Clematis, Atragene, Thalictrum, Caulophyllum. Helleborus, inemone, Hepatiea, Nelumbium, Ranuneulus, Trollius, Adonis, Hydropeltis, Caltha, Paonia, Coptic.

Properlics. Deobstruent, cathartic, caustic and narcotic. The two last sencra have astringent roots.

\section{Order LXII. Papazeraceuc.}

Calyx free, often 2-leaved and eadueous; sometimes about 5-leaved. Stamens mauy Germ single; style ofteı wanting; stigma divided or lobed, permanent. Fruit a capsule or pod, 1-eelled, many-seeded; seeds attaehed to lateral columellas; alhumen fleshy . corele strait.

Generic names. Chelidonium, Panaver, Sanguinaria, Argemone, Nymphæa, Nuphar, Sarracenia? Fumaria, Corydalis

Propcrtics. Deobstrucn!, cathartic, caustic, antiscorbutic, narcotic, and

* The rcot of the cicuta maculata is a most deadly poison farly in the sprine. On the 10th of April, 1820, Asa H. Manley and Amos Ramsdell, of Rutland, Vermont, ate a small quantity of the root of this plant. 'The former died in two bous, the latter in 36 . They were both under ten years of age. I examined the plast in the ensuing summer, and took specimens which orew from the relnainder of the same root: and was particular in questioning the parents and neighbours respecting the above facts at the same tirne. 
anodyne. The papaver was in use as an anodyne in the time of 'Theophrastus, between three and four hundred years before the Christian era. Dioscorides used the fumaria and clielidonium as antiscorbutics.

\section{Order LXIII. Cruciferac.}

Calyx 4-leaved. Petals 4, disposed in the form of a cross and alternating with the leaves of the calyx. Stamens 6, two of them outer and shorter. Germ single, sitting on the disk-like receptacle which supports the stamens; style 1 or none, stigmas 1 or 2 . Fruit a silique or silicle Seeds with incurved corcles. Stems herbaceous; leaves alternate.

Generic names. Cakile, Draba, Alyssum, Lepidium, Thlaspi, Lunaria, Cochlerria, Iberis, Isatis, Dentaria, Cardamine, Barbarea, Sisymbrium, Erysimum, Cheiranthus, Hesperis, Arabis, Turritis, Raphanus, Brassica, Sinapis.

Propertics. Apcricnt, diuretic, antiscorbutic, nutrienlic and emollient. Plants of this order have been used as emollients and diuretics, and as remedies in the jaundice, for several centurics.

\section{Order LXIV. Capparides.}

Calyx polypliyllous, or monophyllons and parted. Petals 4 or 5. Stamens often iudefinite. Gerin stiped, style short or none, stigma simple. Porl or berry many. seeded. Corcle of the seed incurved.

Generic names. Reseda, Parnassia, Cleome.

Froperties. Feeble aperients; excepting the Cleome, which is an aclive enthartic and emetie, and considerably nareotic.

\section{Order LXV. Sapindi.}

The have no plants of this order in our district. The soap berry of the Southern States is placed here.

I'roperties. Einollicnt.

\section{Order LXVI. Acer $\alpha$.}

Calyx monophyllous, permanent, 5-cleft. Petals 5 (or none) with rlaws, inserted on a disk below the germ, and alternating with the lobes of the calyx. Stamens distinct and inserted on the disk with the corol. Germ free. Stigmas 1 or 2. Capsules 2 or 3.celled, 1-seeded. Gtems woody; leaves opposite.

Generic numes. Acer, Aesculus.

I'ropertics. Apericnt.

\section{Order LXVII. Malpighiae.}

Wie have no plants of this order in our district.

I'ropcrties. Aperient.

\section{Order LXVIII. Hyperica.}

Calyx monophyllous, 4 or 5-parted. Petals 4 for 5 . Stamens numerous, sometimes united by their filaments in several parcels. Germ single, free; styles 3 to 5 . Capsule 1 to $5 \cdot$ celled, 3 to $5 \cdot$ valved, with inllesel margins, many-seeded. Seed without albumen, corcle strait. reares opnosite, often glandular; llowers yellow or yellorvish. 
Generic namcs. Hypericum, Ascyrum, Dionaca, 1)rosena."

Properties. Tonic and vulnerary.

\section{Order LXIX. Guttifcrac.}

We have no plants of this order in our district.

Propcrtics. Expeclorants and secernant slimulanls.

\section{Order LXY. Aurantia.}

Calyx monophyllous. Petals 4 or 5 ; stamens often united by their tilaments in several parcels. Berry many-seeded. Corcle strait. Stem. woody ; leaves glandular.

reneric name. Citrus.

Properlics. Tonics and refrigcrants.

\section{Order LXXI. Melia.}

Calyx monophyllous. Petals 4 to 9 , often adbering at the base. Stamens sometimes adhering by their filaments, equal in number t" the petals or double. Germ single, free; style 1. Berry or capsul. many-celled. Seed witlout albumen, corcle strait. Stems woody. leaves alternate.

Gencric names. Melia, Thea.

Propertics. Astringent and feebly narcotic.

\section{Order LXXII. Viles.}

Calyx monophyllons, short, subentire. Petals 4 to 6 , broader at th. . base. Stamens equal in number, and opposite to the petals, and in serted on a disk beneath the germ. Germ single, free; style 1 or nons: Berry 1 or many-celled, 1 or many-seeded. Seed bony and destitute of albumen, curcle strait, cotyledons flat. Stems woody and clinl, ing; leaves alternate; tendrils opposite to the leaves.

Generic names. Vitis, An pelopsis.

Propertics Tonics and refrigerauts.

\section{Order LXXIII. Gerania.}

Calyx permanent, 5-parted or 5-leaved. Petals 5, with elaws, gen. erally unequal or irregular. Stamens 5 to 10 ; filaments often une rqual, sometimes united at the base. Germ single, free, often 5 angled. sometimes surrounded by a gland; style 1, stigmas oftell 5 . Seed without albumen, corcle incurved. Stems herbaceous; leaves often stipuled.

Generic names. Geranium, Palargonium, Erodium. Geranioits. Oxalis, Impatiens, Tropoeolum.

Properties. Tonics, refrigerants and fceble narcotics.

The geranioids ought to be disposed of differently.

\section{Order LXXIV. Malvaceac.}

Calyx often double with the inner one monophyllous. Petals 5 , regular, generally adhering to the base of the filaments. Stanens innumerable, united by their filaments. Germ free, simple, often lobed, stigmas many. Fruit many-capsulec or many-celled. Seed withou?

$\approx$ See Nuttall, page 279 . 
albumen ; corcle lobed, incurved and wrimkled. Leaves alternate, simple, stipuled.

Generic names. Gordonia, Napaea, Sida, Hibiscus, Malva, Althaea, Iavatera, Gossipium.

Properties. Emollien! and aperient. Plants of this order were used as aperients and for sheathing the stomach when any acrid substance: bad been taken into it, by Dioscorides and other ancient physicians; and Hippocrates valued them highly for their vulnerary qualities.

\section{Order LXXV. Magnoliae.}

Calyx 3-leaved. Petals 6 or 9. Stamens many, not united. Germs many, arranged on an elongated receptacle in the form of a cone. Capsules many, 1 or 2 -sceded. Seed with fleshy albumen and strait corcle. Stems woody ; leaves alernate, having caducous stipules.

Generic namos. Magnolia, Liriodendron.

I'roperties. Tonics.

\section{Order LXXVI. Annonae.}

Calyx 3-leaved. Peta!s 6. Stamens many. Germs 2 or more. Berries or capsules 2 or more, 1-seeded. Seed compressed, corcle minute, albumen solid. Stems shrubby; leaves alternate and destitute of stipules.

Generic name. Porcelia.

I'ropertics. Torics.

\section{Order LXXIII. Menisperma.}

Calyx 4 or 6-leaved. Corol none or more than 5-petalled. Flowers dioecious - stamens adnate-germs and styles 3 to 6 . Drupes or berries 1 -seeded. Seed with fleshy albumen, corcle at the summit. Stems woody, mostly twining or climbing. Leaves alternate, simple, iestitute of stipules.

Generic name. Menispermum.

f'ropertics. Weak narcotics.

\section{Order LXXVIII. Berberides.}

Culyx polyphyllous or deeply parted. Petals equalling the divisions of the calys in number. Stamens equalling the petals in number and opposite to them. Germ simple, free: style 1 or none. Fruit 1celled, often many-seeded. Seed aftixed to the bottom of the cell; albumen fleshy, corcle strait. Stems woody; leaves alternate. Flow* ers yellow.

Gencric names. Berberis, Hamamelis.

Properties. Astringents and refrigerarts.

\section{Order LXXIX. Tiliaceae.}

Calyx polyphyllous or many parted. Petals alternating with the divisions of the calyx. Stamens innumerable. Germ simple, free. Berry or capsule 1-or many-celled, 1- or many-seeded. Seed witls fleshy albumen; corcle subincurved, tat. Stemas woody; leaves al. ternate, simple, stipuled.

Generic name. 'Tilia.

2roperties. Emollicnt and aperient. 


\section{Order LXXX. Cisti.}

Calys 5.parted. Petals 5. Stamens 5 or more. Germ single, free style 1. Capsule with many seeds attaclied to the middle of the valve, or base of the cells. Albumen fleshy or corneous. Leaves stipuled.

First division. Petals equal. Stamens more than 5. Seed with a curved or spiral corcle.

Generic namcs. Cistus, Hudsonia.*

Second division. Petals unequal. Stamens 6. Seed with a strait corcle.

Gencrie name. Viola.

\section{Order LXXXI. Rutaceae.}

Calyx monophyllous, 5-lobed. Petals 5, alternating with the lobes of the calyx. Stamens 10 or 15 . Germ simple, free; style 1. Fruit many-capsuled or many-celled. Seed with fat cotyledons and strait corcle.

Generic name. Ruta.

Propertics. Caustic and catharlie.

\section{Order LXXXII. Caryophylleue.}

Caly $x$ often permanent, 4 or 5 -toothed, or 4 or 5 -leaved. Petals 4 or 5 (sometimes wanting) with claws, alternating with the divisions of the calyx. Stamens often donble the number of the petals; some. times equal and alternating with them. Germs simple, sometimes sub-stiped; styles 3 to 5 . Capsule many-valved, dehiscent at the top. Seeds affixed to the centre of the base of the capsule; albumen farinaceous ; corcle involute. Stems with joints ; leaves opposite, entire

Generic namcs. Dianthus, Saponaria, Lychnis, Agrostemma, Silene Cucubalıs, Cerastium, Arenaria, Spergula, Linum, Sarothra, Sagina, Lechea, Mollugo, Queria, Stellaria.

Proportics. Emollient and apcrient. This order comprises those plants which are called pinks, chickweeds and flax. Flax-seed lıas been used as an emollient and aperient more than two thousand years.

CLASS TENTH. Stamens surrounding the germ and attached to a monophyllous calyx.

\section{Order LXXXIII. Sempervivae.}

Calyx free, parted. Corol inserted at the base of the calyx; petals (or the deep divisions) equalling in number the divisions of the calyx. Stamens equal or double the number of petals. Germs equalling the number of petals, or laving an equal number of lobes. Capsules (or follicles) 1-celled, opening on one side longitudinally, mariy-seeded. Seed with a slender, fleshy albumen, and strait corcle. Stems herba. ceous; leaves mostly flesliy ; inflorescence a cyme.

Generie names. Sedum, Sempervivum, Penthorum, Tillaca,

Properties. Emollient and vulnerary.

\section{Order LXXXIV. Saxifragae.}

Calyx adhering, rarely free, limbs 5 -lobed. Petals 4 or 5 , (sometimes wanting) inserted at the top of the calyx, and alternating with its

* See Nuttall, rol. 2, p. 4 , 
divisions. Stamens inserted with the petals, and are equal or double in number. Styles 2, permanent. Capsule 2.beaked, 2-valved, 1 or 2-celled, dehiscent by a terminal pore. Seeds inserted on the base of the capsule or the inflexed edges of the valves; albumen lleshy, corcle strait

Gencric names. Heuchera, Hedyotis, Saxifraga, Tiarella, Mitella, Chrysosplenium, Hydrangea? Hortensia?

Properties. Tonics.

\section{Order LXXXI. Cacti.}

Calyx adhering to the germ, 5.cleft. Petals inserted on the calyx. Style 1, stigma cleft. Berry 1-celled, many-seeded.

First division. Petals indefinite. Stanens indefinite. Style tubulose, stigma many-cleft. Berry umbilicate. Seed without albumen, corols incurved.

Generic name. Cactus.

Stcond division. Petals 5. Stamens 5. Style 2-clelt. Berry glo. iose. Seed with corneous albumen, corcle strait.

Generic nume. Ribes.

Properties. Refrigerants and emollients.

\section{Order LXXXVI. Portulacceac.}

Calyx divided at the top. Corol inserted on the calyx, 1 or 5-petalled (rarely wanting.) Stamens inserted on the corol. Germ free or adhering at the base; style 1 to 3 , or none. Capsule 1 or many-celled, 1 or many-seeded. Seed with an incurved or ring-like corcle, surrounding a farinacenus albumen

Generic names. Portulacca, Claytonia, Sclerantbus, Crypta.

Properties. Emollient.

\section{Order LXXXVIT. Ficoidece.}

Calyx parted, free or adhering to the germ. Petals inserted on the top of the calyx, sometimes adhering a little at the base. Stamens in. definite in number, inserted with the petals. Styles many. Capsule or drupe many-celled. Seed aftixed to the inner angles of the cells. Corcle incurved, and surrounding a farinaceous albumen. Leaves succulent.

Generic name. Mesembryanthemum.

Properties. Refrigerant and emollient.

\section{Order LXXXVIII. Onagrac.}

Calyx adhering to the germ, tubular, divided at the top. Petals generally 4, (rarely none) inserted on the top of the calyx. Stamens inserted with the petals, equalling or double their number. Germs many; style 1 . Fruit many-celled, many-seeded; seeds aftixed to the top of the cells; albumen wanting, corcle strait, rostel superior and longer than the cotyledons.

Generic names. Circaea, Ludwigia, Isnardia, Gaura, Epilobium, Denothera, Myriophyllum, Serpicula. Onagraoids, with single germs. Callitriche, Hippuris.

Properties. Tonics and apcricnts, 


\section{Order LXXXIX. Myrli.}

Calys adluering to the germ, permanent, divided. Petals generally 5. inserted on the top of the calyx. Stumens 20 or more, inserted on the calyx under the petals. Style 1. Fruit many-seeded, 1 or manycelled. Seed without albumen, corcle strait or curved; cotyledons that. Stems woody; leaves generally opposite, and often with pcllucid. punctures.

Generic names. Philadelphus, Myrtus.

Properics. Tonics.

\section{Order XC. Mclosinmac.}

Calyx tubular, 4 or 5 -cleft. Petals equal in number to the divisions of the calyx, and alternating with them, inserted on the top of it. Sta. mens double the number of petals. Germ enclosed by the calyx Seed without albumen, corcle incurved. Stems berbaceous; learcs opposite, simple, nerved.

Gencric name. Rhesia.

Properties. Fcebly tonics.

\section{Order XCI. Salicariae.}

Calyx free, tubular, permanent. Petals inserted at the top of the caly $x$, sometimes wanting. Stamens inserted in the middle of the calys, equalling, or double, the number of divisions. Germ single, style 1. Cajsule covered by the calyx, 1 or many-celled. Seeds nu. merous, affixed to a central cohmella; without albumen, corcle strait, rostel inferior. Leaves mostly opposite.

Generic names. Lythrum, Glaux, Ceratophyllum, Ammannia, Cuphea.

Properlics. Deobstruent and cathartic.

\section{Order XCII. Iiosaceae.}

Calyx mostly permanent, divided, covering the germ, cither adhering or free. Petals inserted on the top of the calyx, generaliy 5, alternating with the divisions of the calyx. Stamens indefinite in number. Germs single or many. Fruit various. Seed with a lateral hilum under the apex, to which the funicle is attached springing from the bottom of the pericarp; albumen none, corcle strait. Stems woody or herhaceous; leaves alternate.

First division, Pomaceae. Calyx 5-celled. Petals 5. Germ single, adhering to the calyx. Styles many. Pome umbilicate, crowned with the lobes of the calyx, many-celled. Seed with the rostel inferior. Stems woody. Flowers complete and perfect. Stamens about 20. bus.

Generic rames. Pyrus, Aronia, Punica, Crataegus, Mespilus, Sor-

Second division, Rosae. Germs many, 1-seeded, concealed within the calyx, which is contracted at the neck; style 1 to each germ. Rostel of the seed superior. Stem woody. Flowers complete and perfect. Stamens about 20 . Leaves pinnate, with stipules adhering to the pelioles.

Generic name. Rosa.

Third division, Agrimonice. Germs generally 2, each with 1.style. and 1 -seeded, concealed within the urceolate calys. Rostel of the seed 
stuperior. Stems luerbaceous or woody. Flowers sometimes apetalous and monoeceous. Leaves pinnate or digitate.

Gcncric names. Poterium, Sanguisorba, Agrimonia.

Fourth division, Dryadcae. Germs many; each 1 -seeded, free, inserted on a general receptacle, style 1 to each. Rostel of the seect superior. Stems herbaceous, or suffructicnse. Stamens about 20.

Gencric namcs. Potentilla, Fragaria, Dalibarda, Comarum, Geum, Riubus, Calycanthus.

Fifih division, Ulmariae. Germs many, free, each having 1 style. Capsules equal in number to the germs, 1 or many-seeded. Rostel at the seed superior. Flowers mostly complete and perfect. Stamens indefinite in number.

Generic names. Spira, Gillenia.

Sixth division, Drupaccac. Germ single, free, style one. Drupe with a 1 or 2 -seeded nucleus; -internal membrane of the seed somewhat fleshy and tumid. Rustel superior. Stems woody. Flowers complete and perfect. Stamens indefinite in number. Leaves simple, having glandular bases or petioles. Calyx 5-lobed; petals 5.

Gencric names. Prunus, Armeniaca, Anygdalus.

Irupertics. Refrigerants, tonics and astringents.

\section{Order XCIII. Leguminosac.}

Calyx often 5-cleft or 5-parted. Corol 5-petalled, inserted on the calyx, consisting of a banuer, two wings and a ket?. Stamens general ly 10, mostly united in two sets, 9 and 1 ; sometimes in one set, and sornetimes they are free. Germ free, style 1. Legume generally 2. valved, 1-celled; sometimes transversely divided into several cells. Seeds aflised to the suturc of one side; without albumen; cotyledons thick. Stem woody or herbaceous; leaves alternate, often compound; stipules axillary-leafets often close up at evening.

First division. Stamens all distinct.

Grueric names. Cassia, Cercis, Baptisia.

second division. Stamens united ly their filaments in one set.

Gicneric namies. Ulex, Mimosa, Genista, Crotolaria, Arachis, Amorpha, Lupinus, Spartium.

Third division. Stamens united, 9 in one set, and one separate. Legume l-celled. Cetyledons always rise up out of the earth when the plant commences its growth, and become succulent leaves. Leaves ternate or pinnate, with a terminal leafet.

Gennric numes. Trifolium, Melilotus, Medicago, Trigonella, Phaseolus, Glycine, Galactia, Vexillaria, Glycyrrhiza, Galega, Indigofera, rubiuea, Colutea.

rourth division?. Stamens united, 9 in one set, and 1 separate. Le. guue partly divided by an imperfect longitudinal partition.

Generic names. Astragalus, Dolichos?

Fif:h division. Staneris united, 9 in one set, and one separate. "Le. gumes 1-celled. Cotyledons do not rise out of the ground, nor become leaves. Leaves pinnate, without a terminal leafet; but the general petiole terminates in a tendril or filament.

Gencric names. Lathyrus, Pisum, Vicia, Ervum.

Sixlh division. Stamens united, 9 in one set, and one separate I egume transversely divided into rany cclls, cach ccll 1. seeded, na dehiscent spontancously. 
Gencric names. Coronilla, Gleditschia, Hedysarum, Lespedezá, Stylosanthes, Aschynomene.

Properties. Emollicnt, diurctic and apericnt. In the time of Diosrorides and Galen, the same properties were ascribed to this o:der of llants as at this day.

\section{Order ICIV. Terebintaccac.}

Calyx often free, parted. Petals inserted on the base of the calys, and alternating with its divisions, (often wanting.) Stamens inserted with the petals, equal or double in uumber. Fruit various. Seed without albumen, rosiel rellexed iuto lobes. Stems woody; leaves alternate. [This order is not satisfacrorily defined.]

Gencric namcs. Ribus, Juglaus, Carya, Zanthosylum.

Propertics. Cathartic, emelic and narcotic.

\section{Oriler XCV. Rhamni.}

Calyr divided. Corol many-petalled, (sometimes none, and sometimes deeply divided,) inserted on the calyx, and equalling the divisions of the calyx in number. Stamens of the sane number. Germs single, free, surroun:ded by the caiys. Fruit a berry or capsule, manycelled. Seed with flesliy albumen, corcle strait, rostel inferior. Stems woody; leaves stipuled.

Gcncric nancs. Stapliylea, Euonymus, Jlex, Ceanothus, Rliamnus. I'rinos

Propertics. Cathurtic, and somcwhat tonic.

CLASS ELEVENTH. SEction IV. Diclinious or anomalous. Flow. ers generally without petals; stam $\|_{s}$ and pistils mostly in different flowers. [An imperfect definition; for many plants of this class have petals, and are not diclinious. It is a kiud of residue class.]

\section{Order XCVI. Euphorbeac.}

Flowers solitary, spiked, or encircled by involucres. Perianth (or corol) many.partel; sometimes wanting in the pistillate. Stamen. inserted on the receptacle, filaments often articulated in the middle. Germ free, often stiped; styles 1 to 3, 2-cleft. Capsules 2 or 3-seeded; valves elastically dehiscent. Seeds arilled, atlixed at the top of a cenfual columella; corcle; flat, iuvolved iu a fleshy albumen; rostel superior.

Generic numes. Ricinus, Euphorbia, Pliyllantlıus, Acalyplıa, Busus.

Propertics Cathartics, and mild crectics. The seeds of the Ricinns communis had been loug in use as a cathartic, before the time of Di oscorides in the first century.

\section{Order XCVII. Cucurbitaccue.}

Calyx adhering to the germ, contracted above, and then dilated into a 5-cleft limb. Cnrol bell-form, iuserted on the top of the germ, 5lobed, at length witheriug and permanent. Stamens 3 to 5 , inserter] on the contracted part of the calyx, often united; anthers 1-celled oblong, attached to the top of the filament; the staminate flowers have abortive germs. Germ single. Fruit a berry, witl a solid berk, which: 
is often corneous. Seeds many, without albumen; corcle strait; co. tyledons flat. Stems herbaceous, mostly climbing; teaves petioled, alteruate, broad; tendrils are often inserted in the axils of the leaves.

Generic names. Passillora, Mlomordica, Sycios, Cucurbita, Cucumis, Melothria

Propertics. The fruil is mostly refrigerant; the herbage and nas. scous fruil are cmetic and calharlic.

\section{Order XCVIII. Urticac.}

Flowers small, greenish, solitary, in aments, or surrounded by in. volucres. Calys (ur curol) 1-leaved, lobed. Stamens inserted on the base of the calyx Gerın single, free; styles 1 or 2-cleft. Leaves mostly hispid

First division. Arlocarpae Flowers aggregated, sitting on a gen. eral receptacle. Fruit tleshy. Seed having fleshy albumen and curved corcle.

Gencric names. Ficus, Morus.

Sccond division. Urliceac. Flowers solitary, on aments or spikes. Fruit never lleshy Seed withnut albumen; corcle often strait.

Generic names. Urtica, Bohmeria, Parietaria, Cannabis, Humulue, Ambrosia, Xanthinn.*

Properlics. Tonics.

\section{Order XCIX. Amenlaceac.}

Staminate flowers in aments, furnished with scales on which the stamens are inserted. Pistiliale flowers have scales or perianths; germs free; stigmas many Fruit bony or membranaceous. Seed without albumen; corcle strail, flat. Stems woody; leaves alternate rud caducous. [This description is defective in its application to Celtis and Ulmus.]

First division. Flowers diccious.

Generic names. Salis, Poìulus, Myrica.

Secoud dirision. Flowers moncecious.

Gencric namcs. Betula, A!nus, Carpinus, Ostrya, Fagus, Castanea, Corylus, Qnercus. Platanus, Liquedambar, Comptonia.

Third dicision. Flowers perfect.

Generic names. Vothergillia, Celtis, Ulmus.

Properlies. Tonics and astringents.

\section{Order C. Coniferae.}

Staminate flowers in aments, each furnished with a scale or periantis supporting the stamens. Pistillate flowers in strobiles, each furnisher with a hard scale. Fruit bony or menubranaceous. Seed with a cylindric corcle in the centre of fleshy albumen. Stems woody; leaveg evergreen; juice resinous.

Generic namcs. Pinus, Cupressus, Thuja.

Sub-orler, Juniperi. Fruil a berry or drupe.

Goneric names Juniperus, Taxus.

* Some botanists place the two last genera in the orcler corymbiferx, also in the Linnean class srucenesia. I see no good reason for these innovations. See De Lamarck and De Candollc p 183. 
Properties. Seccrnant slimulanls and expectorants. The resinous juice ebtained from these plants has been applied as a remedy to wounds and old ulcers for more than two thousand years. Various prepara. tions, as tar-water, decoctions of the bark, \&ic have been used with various success from the time of Dioscorides, and probably muclicar lier, in pulmonary complaints.

\section{General Ruzes ror avolding Polsons.}

\section{Plants nol poisonous.}

1. Plants with a glume calyx, never poisonous. As Whent, Indian corn, Foxtail grass, Sedge grass, Oats. Linneus.

2. Plants whose stamens stand on the calyx, never poisonous. As Currant, Apple, Peach, Strawherry, Thorn. Smilh, p. 392.

3. Plants with cruciform flowers, rarely if evel poisonous. As Mustard, Calsbage, Water-cress, Turnip. Smilh, p. 487.

4. Plants with papilionaccous fowers, rarely if ever poisonous. As Pea, Bean, Locusi tree, W ild indigo, Clover. Smilh, p. 446.

5. Plants with lubiate corols, bearing seeds without pericarns, never poisınous. As Catmint, Hyssop, Mint, Mother-wort, Majoram. Smilh, p. 434.

6. Plants witl compound flowers, rarely poisonous. As Sunflower, Dandelion, Lettuce, Burdock. Milne.

\section{Poisonous Plahls.}

1. Plants with 5 stamens and one pistil, with a dull-coloure lurid rornl, and of a nauseous sickly smell, always poisonous. As Tobacco, Thorn-apple, Henbane, Niglstshade. The degree of poison is dininished where the flower is brighter coloured and the sinell is less wauseous As potatoe is less poisonous, though of the same genus with nightshade. Smith, p. 415 .

2. Umbelliferous plants of the aquatic kind, and of a nauseous scent, are always p-isonous. As Water-hemlock, Cow-parsley But if the smell be pleasant, and they grow in dry land, they are not poisonous. As Fenuel, Dill, Coriander, Swoet-cicely. Smilh, 416.

3. Plants with labiale corols and seeds in capsules, irequently poisonous. As Sıapdragon, Fuxglove. Similh.

4. Plants from which $i$ sues a milky juice on being broken, are poisonous, unless they bear compound flowers. As Milkweed, Dogbane, Milue's Contorta and Lactescentia.

5. Plants having any appendage to the calyx or coral, and twelve or more stamens, generally poisonous. As Columbine, Crowfont. Linneus.

\section{Mosl general Rule.}

Plants with few stamens, not frequently poisonous, except the num. ber be five; but if the mumber be twelve or more, and the smell nauscous, heavy and sickly, the plants are generally poisunous Milne's Multisiliqua and Sapor

Nole. Mauy plants possess some degree of the narcotic principle,

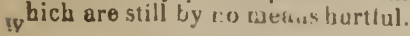




\section{VEGETABLE PHYSIOLOGY.}

This Grammar was prepared for aiding students in the study of Analytical Botany. But the Physiology of Vegetation should occupy a small proportion of the time devoted to Allalytical, or Systematical Botany ; to prepare him for understanding some principles which lie directly in his way.

Vegetable Physiology, Phytology, and the Philosophy of Vegetation, mean nearly the same thing. It is the science which treats of $: 1$. The germination and growth of a plant from the seed. 2 . The propagation of a plant 3. The increase of the growth of a perennial plant. 4. The exterual and internal structure and constituent organs of a plant, with their uses in its economy. 5. The properties of a plant in relation to other bodies.

\section{The Germination and Growte of Plants frod the Seed.}

If a seed be immersed in warm water for a considerable time, and then subjected to a high magnifying power, the elementary form of the future plant may be seen. In some seeds even the embryo of the future flower becomes manifest. Therefore it may not be absurd to say, that the germination and growth is effected by the developement of the embryo plant contained in the seed; and that this developement goes on by means of successive supplies of nutriment, which are taken iuto an organized structure adapted to their reception.

But where shall we stop in our views of these elpmentary forins? Shall we say, that within the embryo of the future liower which sometimes become manifest under the microscope, there is probably another seed contaiuing the elementary form of the next generation, and so on ad infinitum?

Fortunately, the present state of the science presents the means of fixing the limit in the most satisfactory manner. For nothing in the physiology of organized beings is better established, than that a perfect future seed cannot be produced without the application of pollen from a stamen to the pistil of a stigma. But if the future seed were perfect in the present one, such an operation would not be necessary. Therefore, by the aid of the microscope and this established law, we are enabled to infer, that a seed may contain the elements of a future plant as far as the flower and empty tegument of the future seed, and uo farther.

\section{The Propagation of Plants.}

There are two methods of propagating plants. First by reproduction; second, by continuation.

1. A plant is reproduced, when it grows immediately from the seed. The potatoe is reproduced, when the seed is taken from the berry, planted and grows. Apple trees are reproduced in the nurseries from seeds, \&c.

2 A plant is continued, when parts taken from its roots, stem, branches, buds, \&c. are transferred to different places, and so cultivated as to continue to grow in several places at the same time, The 
liring uranches or twigs of the same apple tree may continue to grow from the original root, and from liundreds of other ronts in differeut countries at the same time. And it is a fact now well established, that those twigs or grafts, however recently inserted, fcel the effects of age in the same degree with the I wigs remaining on the original tree ; all other circumstances being similar.

The roots of potatces contime in succession in their native torrid regions year after year for a limited period, like the Malaxis and some others of the Urclis family in our ialifude Agriculturalists and gardeners aid thcir progress liert, by housing the roots in winter, and setting them in the earth again in the spring seasol. These too arc groat. ly distributed; so that this plant is vastly extended by the contiuuation of the same individual. But in due time the effects of age become manifest to the cultivalor, and he finds it necessary to reproduce this useful plant fiom the seed.

The Lombardy poplar is becoming enfeebled with age in our country, so that very recent shoots will hardly witbstand a severe winter. The reasun is manifest. There has ncver been a pistillate tree introduced from Euroje ; consequently this tree has neverbeen reproduced here from the seed. IVe thcrefore see but the feeble limbs of an exile in dotake, thougli yet sustained in a thousand localities.

\section{The Increase of Plants, or the enlargement of trem: VOLUME.}

After the first season of growing, all woody plants continue to increase their size, if uo accident occurs, until age terminates their vital energies Their volume is not enlarged from an extension of each tibre or pore; but from the annual acquisition of new ones. These new oncs are always deposited between th: bark and woud.

In the spring seasun a mucilage is forned between the bark and wood, called the camb, or cambium. Towards the decline of the sear it becomes considerably indurates, and seprarates itself into two concentric loollow cylinders of very different thickncsacs. The thinner one is at tached to the bark, and forms its inmer menuraue. The thick one is attached to the wood, and becomes the outer layer of the wood for the uext year.

It is on this account that those trees which long retain their expanding cuticles, present to our land surveyors those paradixial magic-like marks A beech tree, for example, if lettered or figured with a boardmarker, wil] present these marks twenty or thirty years afterwards, both on the cuticle and on the woud, of the year when marked; while the inlervening layers are sound and without a scar. These interposed woody layers, originating in inucilage annually deposited between the bark and wood, gradually separate the marked bark and cuticle from the marked wood, while they grow between these marks and become continuous.

4. The external and internal Structure, and constituent OrGANS OF PLANTS, WITII THEIR USES IN ITS LCONONY.

Plants are bounded externally, in all their parts, with curved lines They are defended by an almost insensible and imperishable menhrane.

* Cre Smith's Flemente of Bntanv 
called the cuticle. This and the other concentric cylinders have been described at p.7. The parenehymous parts of the foliage,consisting wholly of the cellular integument covered with the transparent eutiele, is well adapted (n) the purpose of subjecting the sap to the requisite influence of the atmospliere. This oftice is, to the plant, very analagous to that of the lungs to animals-particulariy the gills of fisl.

The internal structure of a plant is adapted to the reception and circulation of the fluids. The tubes and cells are different in different plants. Large in aquatics, small in evergreens.

The organs arid parts of a plant are adapted to its sitıation, soil, and nature The lichen is furnished with organs adapted to its :low growth and diy leathery texture. The pompkin to its rapid and gigantic growth, suculent herbage, and open texture. The same species will often vary some of its characteristics to accommedate itself to a forced situation. As some trees bear large and almost intire leaves, while in a defended situation, enclosed by other trees. But when left exposed to winds and storms, by having their defenders cut away, their leaves will be diminished in size, enerease in number, and present a deeply divided form.

When trees, which have wide-spreading tops, grow upon a steep side-lill, they aceommodate the direction of their lower spreading limbs to the ascent of the hill.

I might add tnose organs with which a plant is furnished for propagating its seed. Such as the eyret of the dandelion and thistle; and the looks of the hated burdock, which compel shaggy coated auimals to transport the seed; and thus become the unwilling instruments for propogating a plant, which is never sought but as a loathsome drug.

\section{Tue Properties of a Plast in relation to other eodies.}

Animals feed on plants and find them essential to their well-being. But there are many plauts, which affect the animal system very powerfnlly. These plants are studied, with a view to check any morbid action in the animal system, which may be effected by the uses of plants which are found to counteract such morbid action. A classifcation of plants for this purpose has been described in the Natural Orders of Jussieu.

Vegetables are studied for the purpose of learning their properties in relation to unorganized matter also. A profitable application of this kind of knowledge is made in dying, calico-printing, reducing ores by the aid of eharcoal, \&e.

The student will find nuch information on these subjects in Smith's Elements of Botany, Wildenow's Elements, Darwin's Phytology, Sumner's Botany, \&e. 
xin 


\section{BOTANICAL DICTIONARY.}

Is the language of Botany is now extended to every department of Natural Science, I have adcied the common terms which are peculiar to Mincralogy and Zoology, for the purpose of furnishing Schools will a general Dictionary of Natural History.

Noticns.-Words, which are defined in the granmar, will be referred to the pages in the grammar, in order to avoid repetition

Latin words are printed in Italics. When a word is the same in f,atin and English, excepting a terminal letter or two, it is generally onsitted in one of the languages.

$\Lambda$.

IEBRE'viated périanth. Shorter than most perianths in proportion to its breadth.

A BRrt.vin'tion. Altho' any botanist may employ such abbreviations as best suit his purpose, by explaining their import; yet the following are in such general ise, that it is convenient to linow them :

Rad. root.

Eol. leaf.

Stip. stipule.

Flo. flower.

Cal. calyx.

Cor. corol.

Pet. petal.

Stam. stamen.

Fil. filament.

Anth. anther.

Pist. pistil.

Stig. stigma.

Fr. fruit.

Ph. leafet of calyx, or Icaf.

Per. pericarp.

Mas. stainiuate flower.

Fem. pistillate flower.

Neu. nentral flower.

Her. perfect flower.

3 annual.

$\delta$ biennial.

if perennial.

if woody.
Abbrcvia'tus. See abbreviated.

A вDоми'nat. Belonging to, or situated on, the abdomen; as fius; rings, \&c.

Abor'ticns. See abortive.

ABOR'TIVE flower. Not arrivino to perfection; the proof of which is the want of perfect secd.

- secd. Not increasing, or no: becoming perfect for want of the reception of polten by way ot the stigma.

- pistit. Defective in some essential part.

- stamens. Not furnished with anthers; or with those whick have no opening celis, or which are mere sketclies or Iudiments of antluers.

Anrupt' leaf. A pinnate leaf, -which has not an odd, or terminal leafet.

-_root. Appearing as if bitten off; as bird-foot violet.

Abrup'tc. Abruptly.

Acalyc'inus. IVithout a calyx. Acau'lis. Stemless.

Ac'cessory. Additional. Annesed and of a different kind, often applied to the border of the receptacle of a lichen.

ACERo'se leaf. Needle-form. Ge nerally inserted on the sides of branclies, as in the pincis.

Acero'sus. Acerose. 


\section{A G E}

Acicula'ris. Form of a small needle.

Aciancirora leaf. Sabre-form. One edgr sharp and conves, the other thicker and strait or con. cave Cutlass-form.

Acinacifor'mis. Acinaciform

Ac'isw. One of the little globules conslituting a compound berry ; as of the raspberry.

Ac'inus. Acine

Acotylen'onous plants. Having no cotyledons, or seed-lubes: and consequently produciug no seminal leaves. See Cotyledon and Seed-leaves.

Aculea'tus Prickly.

Acu'leus. Prickle.

Acuminate. When the leaf, calyx, \&c. terminate suddenly in a point, which is mo:e or less curved towards onc edge of the leaf.

. Acumina'tus. Awl-pointed. Acuminate.

Acutangula'ris. Sharp-cornered

ACU'TE. Any part of a plant ending without a curved or rounded termin ation. An obuse angle or any wther angle in mathematics, is acute in brtanical langunge

. Icu'te Acutely. As acute-dentatus, sharply toothed.

Acutius'culus Acutish. That is, the apex, corner, \&c. is hardly rounded so as to be called obtuse, and is rather too nearly round to be denominated acute The termin tion ish as a dimi. nutive is now sufficiently au. thorised by Smith, and others ${ }^{*}$

ADEL'PHovs. Applied to plants whuse stamens are united by their filaments, whether in one, two, or more sets.

ADNA'TE Adhering. Any two or more parts of a plant being attached to each other, in cases where analogous parts are separate in other plants. As the bulbous offsets of Daffodil. The stipule in some cases is detached from the petiole, in otliers it is adnate, \&c.
Adna'tus. Growing together. Ail nate.

Adpres'sus. Appressed.

Adsren'dens Ascending.

AD'verse loaf. Presenting its under surface to the sun. One edge presented towards the stem

死quival'vis. Valves of a capsule equal among themselves. It is also applied to valves (chafis) of a glume calyx.

Frugino'sus. Light bluish green, verdigris colour.

死stivitio. Summer residence. See IEstivation.

Estiva'tion. The inanner in which petals lie in the flower. bud, and leaves in the leaf-bud, before they open. 1. Convolute, petals or leaves rolled all one way like a roll of paper or cloth. 2. Imbricate, petals or leaves ly. ing over each other so as to break joints, like shingles on a roof. 3. Conduplicatc, each petal or leaf having its edges rolled in, till the two opposite rolls meet on the ..idrib. 4. Valvate, when, just before they open, they staud like the husks of an ear of Indiau corli. 5. Unequalvalved, when the petals differ in size See Foliation.

Alff'nis. I laving relation, or affi. nity, to something supposed to be previously known.

Aga'mia. (a with.ut, gamia matrimory, Necker's name for the class cryplogamia.

$A^{\prime} G$ es of plants. Some plants spring up, flower, ripen seed, and die in a few hours or a day, which are called ephemeral. Oth. ers live a few months, or a sum. mer, which are called annual. Otbers spring up in one summer and ripen and die the next, which are called biennial. Oth. ers live ân indefinite period, either with the whole stem and branches, or only by the root, which are called perennial.

The ages of trees may bo 


\section{$\triangle \mathrm{M} \mathrm{E}$}

known by counting the concentric rings, or grains. Our au. thor, Richard, supposes that trees liave three ages. 1. The age of increase, or growth. 2. The age of maturity, when there is no increase. 3 . The age of decay. But is there not sufficient proof, that all trees, while in a living state, contiuue to deposit new layers of wood every year? If so, the age of maturity must ke rejected.

AG'GREGATE. Many springing from the same point, or from the same receptacle. Sornetimes this term is rather luosely applied to heaps or bundles.

Aggregate flowers are those where several staud on the same seceptacle without united anthers. 'These flowers have rarely any ieclination to yellow colour like compound flowers ; but are blue, purple, or white. Applied to minerals it signifies that several simple minerals are united in a in ass by adbesion, or by a cement.

A'Grette, E'gret. The flying, featlery or hairy crown of seeds; as the down of thistles and dandelious. It includes whatever remains on the top of the seed after the corol is removed.

- stiped (stipulatus) when it is supported on a foot-stem. _ simple (simplex) when it consists of a bundle of simple hairs, without brancles.

- plumose(plumosus) when each liair has other little liairs arrangcd along its sides, like the beards on a feather.

membranous, thin transparent leaves.

Martyn recommends this term under the word pappus; Barton adopts it, and Ives approves. On these authorities, it is introduced here from the Freuch hotanists.

I'GRETTED. Beariug egret.

la. See Wrisa.
Ala'TED, Ala'tus. Having wings Al'bicans. Whitish, growing white. Albu'nes. The farinaceous, fleshy, or horny substance, which constitutes the chief bulk of monocotyledonous seeds; as wheat, rye, \&c.

Albur'num. See Aubier. Sapwood.

AL'GaE. Linneus comprised the plants of the orders Hepaticæ and Lichenes under this order.

A'Lienated. When the first orgains, as the stamens, leaves, \&cc. give place to others different from the natural babit of the plant.

Alliaceous. Emitting the odour of garlick.

Alluvion. Detritus, which is formed by the process of wash. ing from the place of disintegration.

Ar'pine. Growing most natural. ly on high mountains.

Alter'nate. Branches, leaves, flowers, \&c. are alternate, when arranged upon opposite sides of the stem, or whatever supports them; beginning at different distances from its base, and continuing in nearly equal series. Sometimes they are in three series

ALter'nating. When one organ is arranged alternately respecting another ; as the stamens, in the first ten elasses, mostly alternate with the petals, or divisions of petals.

Alter'ne pinna'ta Alternately piunate.

Alve'ol atte receptacle. Having cells so as to resemble a honeycomb, with more or less of each seed inbedded in it.

Alrcola'tus See alveolate.

Alutaceous. Tan-colour. The colour of soal-leather.

Ambitus. Periphery. The outer rim of a frond, receptacle, \&c.

$A^{\prime}$ MENT. An assemblage of small flower-bearing scales, which serve as lateral calyces. Thes 
are arranged aloug a hind of ra. chis, and each eneloses either the stamens or pistils of llowers. The pine, willow, oak, chesnut, walnut and mettles are good ex. amples.

Amenta'ccus. Growing in aments, amentaceous.

Amen'tum. See ament.

Axpmintologs: The department of Zoology, embracing animals which are eapable of suspending respiration for a long time without produeing bad effeets. As frog, suake, tortoise, lizard. Amplexicau'lis. See clasping. Embracing the stem.

- Am'plius. Enlarged, abundant.

Ampul'lus. See utrieulus. Bladder.

Axal. Situated near the vert, or between it and the tail.

Analluvion. Applied to detritus wlich lias not received its present eharacter from being washed.

ANAL'OGx. In botany, it is frequently neeessa.y to reason from analogy. That is, after becoming acquainted with those organs whieh usually aecompany each other, if we discover one of thein in analysing plants, we frequeritly assume tlie exist. ence of others when the latter are tou minute for inspeetıon. This prineiple becomes indispensable in most cryptogamous plants.

Anal'ysis. To analyse a plant botanically, is to seareh out the name by the number, form, position, sie. of its organs, as tley exist in a natural state.

Anastonosis. A meetiug of mouths. When veins, tubes, \&e. join in one, at, or towards, their extremities.

. $1 n^{\prime}$ ccps See aneipital. Two-edged.

ANcip'ItaL. Two-edged. Having two opposite edges or angles.

A.TDrog'yous plants. Bearing staminate and pistillate flowers on the samo root without any perfect ones; as the Indian corn.

- spilic, las both staminate ani pistillate flowers distinct on diflerest parts of it.

- fower, las stamens or pistils only, and is on the same plant with otluer flowers having dit. furent organs fiom itself.

Androg'ynus. See androgynous.

Axfrae'Tuous. Winding by angular turnings.

Angiocar'pus. Fungi bearing seeds iuternally.

AN'GULAR. By means of iutervening groores, tlie stems, ealyces, eapsules, \&c. often bave ridges running lengthwise, whieh give. them this appellation. Sometimes the angles project eonsiderably; particularly the sidepoints or projeetions of leave-, which are also eallird angles.

Angula'tus. See angular.

Anyustifolius Narrow-leaved.

An'NuTine. Of one vear.

AN'NUAL. Which springs up, perfeets fruit, and dies, in the same year. Tlue herbage is often annual with a perennial root. But the root is always intended, unless the other parts are particu. larly mentioned.

Annula'tus. Having a ring around the eapsules in ferrs; or a fungus witl a ringed stipe. See ring.

An'nulus. See ring.

$A n^{\prime}$ nuus. See annual.

Axom'alous. ( $\alpha$ without, nomos law.) Whatever forms an excep. tion to the assumed rules or sys. tems. In the attempts of oll! botanists at natural arrangement, many plants were necessarily thrown into anomalous groups. Antennae. The horus or jointeil proeesses on the heads of insects. AN'TIIER. See p. 5.

Astilerid'ium. Used by Nuttal! for a mass of pollen. 
pendage; as on the Sarracepiia.

As'Perate, As'per. See rugged. Rough.

Aspcrifol'ius. Rough-leaved.

Assur'GeNT, Assur'gens. Rising in a curve from a declined base

Astíped. Pappis, or a fungus without a stem, or stipe.

Atropurpu'rcus Dark purple.

ATten'Uated, Attenua'tus 'Tapering gradually till it becomes slender. Long and slender

Au'BIEr. Sap-wood, the last year's deposit.

Auc'tus cal'yx. Having an outer row of leafets; as the Dandelion.

Ave'nium Veinless.

Avertebral. Animals without back bones; as insects, oysters, angle-worms

AUlulet. Spurious wings. A tuft of 3 or 5 featluers on the outer fore-joint of a bird's wing.

Aurauti'acus. Orange-coloured.

Aure'us. Gold-coloured.

Auricles. Appendages to the heart; being small cavities above the ventricles.

Auricula'lus, or auri'tus. Sce eared Ear-like.

Autumnalis. Coming to maturity in autumn.

Autumna'tio. The effect of autumn or plants.

AWL'Form. Linear at, and adjoining, the base; and becoming sliarp and more or less curved to one side at the point.

AwL'PoINTED. Acuminate

Awn. A short slender process, or stiff beard, proceeding from the top or back of glumes, or chaff. Processes resembling awns are called by this name, which proceed from anthers or any other parts of vegetables.

AWN'ED. Having awns.

Aws'less. Without awns; sometimes it means a blunt pointless awn.

As'E-Fons. Nearly cylindric to. waras the base, with oue sidc projecting towards the end; which projection is sharp-edg. ed.

Ax'sL. The arm-pit. Applied to vegetables, it means llie angle formed by the meeting of a leaf or petiole witl the stem, or of a branch witl the main stem.

Ax'lllary. Any thing growing froin the asils.

Azu'reus. See Coruleus. Blue.

\section{$\mathbf{B}$}

$B a c^{\prime} c a$. See berry.

Baccif'crus. Berry-bearing.

Baccil'lum. Pedicel of licliens.

BAcK. The side of a univale shell, which is opposite to the side iu which the aperture is placed.

$B a^{\prime}$ dius. Liver-brown.

$B_{A N}{ }^{\prime} E R$. The upper petal in : papilionaceous flower.

BARB. A strait process armed with teeth pointing backwards.

$B a r^{\prime} i a$. See beard.

Barba'lus. See bearded.

Bark. Properly the inner strong filorous purt of the covering of vegetables. But in a more $\mathrm{cx}$. tended sense it includes also the cuticle and cellular inlegumcnt; which see. Also see Curtex.

$\mathrm{BAR}^{\prime}$ REN. Producing no ripe seed. See staminate, neutral and abor. tive.

Bas'is. Base. The part of a stem, leaf, flower, \&c. nearest to the place through which it derives its nutriment. The extreme end of a univalve sbell, opposite to the apex of the spire; and the side or end opposite to the linge of the bivalve shells.

BEAK. One side of the aperture of a univalve shell extended in the form of a beak; as murex. In a bivalve, it is the tip of the spiral part near the hinge.

BEAK'ED. Terminated by a prot cess, formed like a bird's bill. 
BEARd, Parallel hairs. It is applied to the filamentous nectaries on the petals of Iris. The lower lips of ringent corols are sometimes called beard. Tendril-like appendages near the mouth of the sturgeon and of some other fish.

BE'ARDLESS. Destitute of beard. BELr'FORM. Sivelling out at the base and without a tube. Properly applied to monopetalous corols only; but it is frequently extended to liliaceous flowers, and some others.

BELLY. It is the swollen part of the body of a univalve shell. See Body.

Bel'zyisg. See Ventricose. Inflated.

$B_{E} R^{\prime} R Y$. A pulpy pericarp enclosing seeds without capsules.

Bib'ulus. Sucking water.

Bicap'sular. Two capsules to one flower.

Bicor'nis. Anthers with two hor'ns, or two horn-form processes.

Bicus'pidate. Having two lengthened points, each terminated with a small bristle.

Bid'cns. Having two teeth.

BIEN'NIAL. Springing up one summer, flowering and dying the next, as wheat.

Bifa'rius. Facing two ways, presenting two opposite series.

BIF'ERous. Bearing twice in a year. Common in hot climates.

BIFID. Two cleft, split into two divisions.

Bif'idus. Bifid.

Biflo'rus. See two-flowered.

Bif'arus. Having two openings or holes.

Bifurca'tus or Bifur'cus. Forked. BIGEM'INATE. Twin-forked. Having a farked stem with two leaves on each part.

Biglan'dulous. Having two glands.

Bis'vaous. A pinnate leaf with two pairs of leaves on each part. Bila'biatc. Corol with two lips; ns in most of the class didyna onia.

Bilam'ellate. Composed of two lamellæ; it applies to a flattened stigma split lengthwise.

Bilo'bate. Divided into two lobes.

Biloc'ular. Tivo-celled.

BI'NATE. Two standing up together on the top of one stalk. If they spread out horizontally: they are called conjugale.

Biner'vis. Two-nerved.

Bipartible, or Bipar'tille. Na. turally divisible into two parts.

Bipurtitus. Divided into two parts to the base, but still re. maining in one piece; as the. petals of stellaria.

Bipin'Nate. Doubly pinnate.

BIPINNat'IFID. Doubly pinnatifid.

Biros'trate. Having two beaks. Biscriallis. See Lamella. In two thin series.

Bistri'ate. Having two slender lines.

Bisul'cate. Having two furrows or grooves.

BitTES'NATE. Doubly-ternate.

Bi'varve. When a capsule is com. prosed of two pieces, or valves; or when the glume calyx of grass, \&ic. consists of two chaffs, or husks. When used in Zoolo. $\mathrm{gy}$, it refers to the two parts of the shell of such molluscous auimals as oysters, clams, \&c.

Bivasscula'ris. With two horn. form or cup-form cells.

BLIS'TERED See bullate.

Bloom'Ing. The precise time when all parts of the flower are completely developed.

Bros'som. The corol.

Brunt. Round-obtuse.

BOAT'FORM. Hollowed one side with a compressed longitudinal ridge on the opposite side.

BODy. It is the first whorl at the base of a univale shell; the most swollen part of which, is called the belly. 


\section{$\mathrm{BU} \mathrm{U}^{\prime}$}

BOLE. The unked trunk of a tree. BOR'DER in LICHExs. The edging of their receptacles (apothecium.) It is proper, when of the same substance and colour of the receptacle. It is accessory, when of a different substance or colour from the disk of the receptacle.

BOR'DER of corols, leaves, fungus es, \&c. The spreading brim

-tcnuis. 'Thin border' of a fungus.

colorata. Coloured border. - equalis. IVhen the stem of a fungus is in the centre.

- crassa. Thick border, \&c.

Bos'sED. Bunched up in the centre; as ill some ngarics.

Boras'ical Names of plants. They should always have a Latin termination, in order to be equally convenient for all uations.

Bot'rus. A clusler, like grapes.

Bougir. See brancli.

Boulder. A large fragment of a rock. 'Ih is term is applied to all masses of rock, which are severcd from a main rock, if the size is above that which is usually denominated a pebble.

Kow'ED Curved over downwards. BOWL'-Fory. About half of a linllow sphere.

Brac'niate. Branches nearly horizontal and decussalc.

Brachium. See Measures. Armslength.

Bract. Bracted. Floral leaf. A leaf near or among flowers, which differs in shape, or colour, or both, from the other leaves of the plant; as on the bass-wood, (tilia.)

Bractca'tus. Bracted, having bracts. Bractcifor'mis. Resembling bracts. Branch. A division of the main stem, or main root.

BRANCII'FD. Divided into branches. Applied to roots of trees.

Branch-LEAVEs. Leaves growing on branches.

BRANCH'LET. branch; a twig.
Brancir-pr:Duncle. A peduncle proceeding from a lranch.

Brev'is. Short.

Brevis'simus. Very short.

Brist'LEs. Very stiff hairs. They are simple or hooked.

Brist LE-Form. Nearly proportioned to a bristle in length and breadth.

BR.1ST'LY. Set with bristles.

Bronchial. Applied to fish it means, pertaining to the gills.

Bruma'iis. See Ilyemalis. Win. tery.

Brun'sevs. Brown, dusky, dun.

BuD. The wirter residence of leaves and tlowers. Generally wanting in hot countries. They ar + drferided by imbricate scales and mostly by a clammy glutinous substance also. They are:

1. Leaf-bearing. Which arc more slender and sharp.

2 Flow'cr-bearing. Which are thicker, wotso liard nor so sharp.

3. Leaf and flow'cr-bcaring. Which are generally smallel than either of the other kinds. See foliation.

Buls. Bulbus. Bulbous roots Througl we call the turnip, the onion, sec. roots, they are strictly buds; or tle winter residence of the future plants. Some bulbs are borlue above ground, as on several species of onion, (alli. um.)

Bulbif'crous. Producing bulbs above ground.

Bulbo'sus. Bulbous. Growing from bulbs.

BULB'ous ruot. Fleshy and spherical

Bul'bulus. Small laterol bulbs shooting from larger ones.

Buz'late Raised in bunclies or blisters; as wben the parenchy. mous substance of a leaf rises up lietween the veins.

Buñle. See fascicle.

BUT'TERFL FonM. See papilion. aceous.

Buт'rons, Tri'ca. That kind of receptacle of lichens which 
when inagnified rescmbles a coiled horse-hair. They are loundish, sessile, unexpanding, compact, black, and solid; continued along their whole surface Upper side they are in concentric, or coiled, plaited and twisted folds ; covered eve. ry where with the same membrane; containing seeds without cells, or cases. Sinith.

Byssus. Flax-like, silky, or hairlike fibres at the hinge of some bivalve shells. It is applied to some fungi, \&ac.

\section{C.}

C.ANU'cous. Any part of a plant is caducous, which falls off ear. lier, compared with other parts of the same plant, than is usual for similar parts in most plants. As the calyx of the poppy falls off before the corol is hardly expanded.

Ca'sius. grey.

CaEs'Pitose. Turfy. Several plants growing together, or from the same ront, forming a turf.

Cal'amus. Reed-like.

Cal'car. A conic spur. See Spur. CaL'carate. See spurred.

Calciferous. Bearing calx. An old term for carbonate of lime. Applied (1) sandrocks, \&c. which contain carbonate of lime.

Calic'iforal. See Calyciform. Cup-like.

Caxic'urate, Calicula'tus. Having a smaller outer calyx. See auctus.

$\mathrm{C}_{\Lambda}^{\prime}$ tix. See Calyx. Leaf-cup.

CaLYciforu. Resembling a perianth calyx.

CA'LYCINE. Appertaining to a calyx.

Calyc'inus or Calic'inus. See Calycine.

CA'rycte. The outer calys-like part of the crown of some sceds. Also sce auctus.
('a'Lxcled. Sce auctus. Having an outer calyx.

Calyciulus See calycle.

Calyp'tra. Calyptre, or veil. The cap or hond of pistillate mosses ; resembling in form and position an extinguisher set on a candle. It is ranked among calyses, and so used in descriptions. But in reality it is the corol closed; which after being detached at the lase like other corols, its form still keeps it on the cap. sule a while. See villose, also Perishatium, which is the true caly's of mosses.

Calyptra'tus. Having a calyptre.

$\mathrm{C}^{\prime}$ Lyx. (Kalux, Gr.) That floral organ which proceeds from the germ, rcceptacle, or peduncle, below all the other organs.

If the stamens alternate with the leafets or divisions, Linneus calls it a corol ; and if the stamens stand opposite to the leafets or divisions, lie calls it a calys, without regarding the colour or texture. Where the stainens are numerous, this rule cannot apply; neither bas Linneus made it necessary in his descriptions.

IVildenow's rule. The calys is hardly as long as the stamen; the cornl quite as long or longer, the calyx green and firm; the corol eoloured and tender. This rule is to apply where but one of the organs is present; and he allows a few exceptions to this.

- dowble. When one calyx is outside of anther; as in the holly-hock, (althea.)

- common. When one calyx includes many florets, as the thistle

- proper. When a floret is included in a general calys of its own.

There are seven kinds of ca$1 y \bar{\Sigma}: 1$. Perianth. 2. Involucre. 3. Spathe. 4. Glume. 5. Ament. 
6. Calyptre $\%$ Volva. See each.

Cams, Cam'lium. Du Hamel's name for the mucilaginous or gelatinous substance between the wood and bark. See p.7.

Campan'ulate, Campanula'tus. See bell-form.

C'ampes'tris. Growing in uncultivaled fields.

CanaL. The channel or gutter along the beak of a univalie shell.

Canalicula'tus. See channelled.

Can'crllats, Cancella'lus. See latticed.

Canescent. Becoming white or hoary.

Capilla'ceus. See capillary.

Cap'illary, Capilla'ris, Capilla'. ceus. Hair form; longer than uristle-form in proportion to its thickness.

Capillus. Hair. See pilus.

Car'itate, Capila'lus.

furm ; growing in heads.

Capil'ulum. See head.

Capre'olus. See tendril.

Caprification. The fertilizing of pistillate flowers by sprinkling pollen upon them. This is important in raising figs.

CAP'sule, (cap'sula), a little chest. That kind of pericarp, which opens by valves and becomes dry when ripe ; not in. cluding siliques nor legumes. When it is one-valved, it is called н FollicLe, folliculus, which see. It consists of valves, partitions, columella, and cells, which see. One kind of cap. sule never opens and is called sumara.

Cari'ua. Sec licel.

Can'inate. See keeled.

Carina'tus. See keeled.

Can'xeous, Car'neus. Flesh-col. oured. Nuttall uses it for fleshy.

Carvo'se, Carno'sus. Fleshy.

CAR"POGENA'TION. (Karpos, fruit ; gennao, to bring forth.) A sub. stitute for the word fructifica. tion.
Cartilage. Flexible, flurous, compact substance; often call. ed gristle. Applied to aniusals mostly.

Cantilag'inous. Hard and somewhat flesible. It applies to a leaf, when it is bound around with a strong margin, different from the disk of the leat.

Caroncle. Fleshy protuberance on the heads of some birds, as turkies.

Caryophyl'leous. Pink-like, as to the corol; having five petals with long claws, all regular and set in a tubular calyx.

Catapilracten. Callous skin, ol cartilaginous scahs.

Castra'ta. Filaments being witl. oit anthers.

Cate'nula. A thrcad in some mos. ses, serving to unite or chain together the seeds.

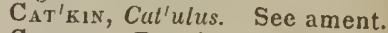

CaUdal. Pertaining to the tail or posterior extremity.

Caúnate, Cau'da. See tail.

Cau'dex. The main body of a tree or root.

Caules'rent, caules'cens. Having a caulis, or stem, exclusive of the peduncle or scape.

CAU'LiNe, cau'linus. Growing on the main stem.

Cau'lis. The nıain herbage-bearing stem of all plants, except of the grassy kind; as trees, weeds, \&ic. We have no English name for this stem, unless we adopt the Frencli, tige.

Clll, The hollow part, or cavity of a pericarp or anther. It is more generally applied to the cavities of pericarps, whert seeds are lodged. According to the numbers of these the pericarps are called one-celled, two. celled, dic.

Cel'Lular integ'udent. The parenchymatous substance betiveen the cuticle and bark. This substance is generally green. It constitutes the most considerable part of leaves; in 
which the juices are operated upon by air and light, and the peculiar secretions of vegetables principally elaborated.

Cen'lules, cis'tule. That kind of receptacle of lichens, which is globose, terminal, and formed of the substance of the frond. It is filled with uncoated seeds, intermixed with fibres; at length it hursts irregularly. Sinith.

Collulo'sus Cellular. Having cavities within, which are small and irregular; and in which sometimes granules are nested.

Ccntra'lis. In the centre.

Cephalo'dia. See knobs.

Cers. Membrane covering the base of a bird's bill.

Cerea'lis. (Ccr'es, goddess of corn.) Any grain of which bread is made.

Cor'nuus. When the apex or top only droops or bends down. See nutans, and the dilference in the two terms.

Cervinus. Faivn-coloured. The colour of the fine light hair of a deer. Very pale reddish yellow. Ces'pitose. See Caspitose. Turfy.

Craff. Thin membranous covering of the seeds of grass, grain, scc. See glume. It is also applied to whatever resembles chaff; as the substance left on the receptacles of some com. pound flowers, after the seeds are removed; to the crown of some seeds, \&c.

CunF'Fy. Bearing chaff.

Chambers. The cells, or separate spaces, in shells. They are connected by a siphunculus.

Cran'Nelled. Hollowed out longitudinally with a rounded groove of considerable depth.

CUAR'ACTER. Tluat description of a plant, which distinguishes it from all others. In making out the character, situation, proportion, connection, number and figure, are considered,
The two last are not so constant as the other three.

Geueric characters are limited to the flower and fruit.

Specific clsaracters are re. stricted no fartleer, than to a void running into the characters of the genus.

Chelate claws. At the end of fore-legs of some insects. They resemble forceps, like lobsters' claws.

Cho'ron. A clear limpid liquor contained in a seed in the time of flowering. This liquor, after the nollen is received, becomes a perfect embryo of a new plant, and takes the consistence usual in perfect seeds. But withouf the reception of the pollen, neither any thing like the embryo or perfect seed, is ever formed. Malpighi.

Chrysoe'omus. Golden locks; or a yellow bundle of threads.

Cic $^{i}$ atrice, Cica'trix. The mark $^{\prime}$ or natural scar from whence the leaf has fallen.

CıL'IATE, cilialus. Edged with parallel hairs or bristles, resenbling eye-lashes.

CINE'REOUs. of the colour of wood-ashes.

Cin'gens. Surrounding, girding around.

Cir'crinat. Rolled in spirally be. giuning with the tip, which con. tinually occupies the centre ; as ferns.

Circina'tus. Circinal. Also compassed about.

Circumsi'sus Cut round. Opening trausversely, not lengthwise; as the carsules of purslain.

Circumscrip'tio. The circumferance of a leaf.

Cirrif'crus. Bearing tendrils.

Crrro'se, cirro'sus. Terminating in a tendril.

Cir'rus. (Curled bushy hair.) A tendril, or climber.

Cis'bula. See Cellules. Jittle hollows. 


\section{I O}

Cray'ar. Sce riscid.

Chas'per. See tendril.

Cras'ping. The hase of the leaf being more or less heart-form and sessile, so that the two hind lobes partly surround the stem.

Cuass, clas'sis. The highest division of bodies in a systcm. Each class is defined to be the agreement of several gencra in the parts of fructification, according to the priuciples of nature, distinguisbed by art Linneus divided all plants by their stamens and prstils, into 24 classes; but Persoon and other approved sysematic writers hase distributed the plants of the 18th and $23 \mathrm{~d}$ classes among the othcrs, and rejucted these two; leaving but $2: 2$ classes. These are rejected on account of the liability of their characters to perpetual variations. On the same ground the class dodecandra may be rejected; leaving but 21 slasses.

Crávatr, clava'lus. Club-form. Growing larger towards the end.

Clavic':ila. See tr udril.

Clau'sus. Closed, shut up,

Cla'vus. See spuried rye. Ergot.

Clast. The lower narrow part of a petal by which it is fixed on the caly $x$ or receptacle. It can exist only in polypetalous corols.

Cleft. Split down, not exceeding half way to the base; with nearly strait edges $n n$ both sides of the fissure. The parts into which it is split are numbered in descriptions; as once split making two divisions, is called 2 . cleft; two splits 3-cleft, \&c.

Clefts, lirel'loe. That kind of receptacle of lichcns, which is open, elongated, sessile, black, very narrow or linear, with a somewhat spongy disk; the border is parallet on each side and proper. Sometimes it has all accessery border from the crust besides. The clefts are either simple and sulitary; or aggre. gate, confluent and brancbed. Sinish.

Cli'mbing. Ascending by means of tendrils, as grapes : by lear. stalks, as virgin's bower; hy cauline radicles, or rootlets, as the crepping American ivs, (rhus radicai.s) It differs from twining, whel see.

Cloaca. I gel, ral vent for eggs, urine, and tiseces, as of birds, \&e.

Chouds. They may be divided into the Regular and Irregular.

\section{Pegular Cluuns.}

1. Slralo'se clouds. They are those stratified horizouta, ranges of vapour, which often appear it the morning, near and adjoining the earth; usually called fog. When the sun shines upon them, they ascend gradually in a highly rarified state; and at length re. unite in another form, and take the name of

2. Cumulo'se clouds. 'They are those bright shining clouds, which lıave their bases straitish with thcir upper sides in roundish brilliant heaps They mostly float awhile near the horizon in detached mas. ses, and then grailually break up and ascend still higher in fine tiakes or sprays, and form

3. Cirro'se clouds. They are those fibrous clouds which resemble flax when it is gradually pulled from the distaff. They are the higliest of all clouds; otten forming at the height of five or six miles. After a few hours, they generally settle down gradually, and becoine

4. Cir'ro-cumulo'sc clouds. They are those which are formed by the knotting or curdling of cirrose clouds. When first forming, they exhibit rows of small heaps, oftel in long regular curved lines very 
Near each othcr. Sornctimes they become confluent, and at length cover the whole sky. This last variety furnishes the materials for loug steady rains. But they generilly break up in fair iveather in the afternoon, and out of their fragments are made

5. Cir'ro-strato'se clouds. T'hey are those stratified patches, seen near the horizon, mostly at evening ; generally disappearing entirely after dark.

Renark. This is the usual process during the pleasant part of spring, summer and autuinn. In the year 1815, I kept an exact diary of clouds at Greenwich, in New York, more than five montlis. I found this to be their regular course more than half of that period

\section{IrRegular Clouds.}

6. Nimbo'se clouds. They are thos̀ dersse clouds, which ascend from the horizon, at first with heads like the cumulose, which sonn shoot into cirrose branches extending toivards the zenith. They are usually called thunder-clouds, and almost always bring showers.

7. Vello'se clouds. They are those fleecy clouds, which fly swiftly about the sky, of an $o_{i}$,en texture, without any defined sides or bases. One variety of those clouds is called scud.

8. Cu'mulo-strato'se clouds. They are the most rare, as well as the most remarkable of clouds. But one arpeared in the year 1815 , and I have nbserved but two since, (13 years.) A cumulous-like cloud seems to rise up from the liorizon in a compressed channel, and to become innited with a cirrostratose cloud. Soon after this union, the cloud spreads out to great extent, and inally covers a great proportion of the liemisphere; while it base or stem remains as at the commencement. Its form and sudden grow th have given it the appellation of mushroom-cloud. J have never seen this cloud except at six or seven o'clock in the afternoon.

CLo'ven. See cleft.

Cuob. The clavate part of a fun. gus, which supports the fruit on bears the seed.

Club'-Form. See clavate.

Clus'tered. See racemed.

Cl. 'peate, Clypea'tus. Form of a buckler. See peltate.

Coad'unate. With united bases. Coagta'neous, Coaeta'nus. Exist. ing at the same time. Applied to willows and to some other plants, it implies that the fowers and leaves appear at the - same time.

Co'Alit, Coali'tls. Thickened, increased, or pressed together, as the anthers of potatoe $10 \mathrm{Wr}$ ers

Coarc'tate. Compact. Pressed or squeezed close together.

CoAT'ED. Consisting of concen. tric coats, layers or skius, as the billbous roots of onions.

Cob'webred. See arachnoideas. Coccin'cus. Scarlet-coloured.

Coc'cum. A grain or seed. Tri coccous, 3-seeded ; pentacoccous, 5 -seeded, \&c.

Coch'LFate, cochlea'lus. Coiled spirally, like a snail-shell.

Cneruleo purpu'reus. Bluish-pu!ple, violet colour.

Cocru'leus. Blue.

Cohe'rens. Cohering, altached.

CoIL'ED. Twisted like a rope : or rather resembling the form ot one thread of a rope, after thr: other threads are removed.

Colli'nus. Growing on bills.

Coloured. Of ally hue excepi. green; but in the language of botanists green parts are $110 \mathrm{t} \mathrm{co}$. lonred. See teniperature, al:o glaucous. 
Colora'lus. Coloured.

Columel'ta. That which connects the seeds to the inside of a pericarp. It is generally applied to a central pillar in a capsule; which takes its rise from the receptacle, aud has seeds attached to it on all sides. In mos. ses it is called sporangidium by willdenow; and be sometimes apples this term as a substitute for columella; and says it is found only in 2 -valved capsules. Applied to shells, it means the pillar formed by the spirc, commencing with the lcit lip.

Coluns. Applied to a thick strong style.

Columinar. Sce terete. Round and tapering.

Columnif'era. Stamens and pis. tils disposed in the form of a column.

Com'a. (Kom'e, a bead of hair.) A tuft of bracts on the top of a spike of flowers.

Comms'sure. The place where one thing or part is joined to another. Nuttall applies it to sides or edges of two seeds, growing on unbelliferous plants. where they are joined together; as those of the carrot and fennel.

Com'mon. Any part is common, which serves to include or sustain several parts, similar among themselves.

- rerianth. Includiug several florets; as in the thistle.

- involucre. Surrounding the base of the peduncles, in an um. bel, which are subdivided above.

This term is often used for frequent also.

Comnu'nis. See common.

Como'se. Having a coma, or lock of hair.

Compac'tr. See coarctus.

CoMPlE'Te, comple'tus. Having both calyx and corol. When the corol is wanting, the flower is in:omplete. When the calyx is warting, the flower is natied if it has a corol.
Con'pricate, complicu'lus. Foldcd together.

Composiltus. Compound.

Con'pound. One wholc, formed of many similar parts.

- flowers. Those coinprised in the class syngenesia, with severa) florets on onte rcceptacle, cach with united anthers. See p. $6 \& 10$.

- leaf. When several leafets grow on one petiole.

- raceme. When several racemes grow along the sidc of a peduncle.

- spike. When several spike. lets grow along the side of a fruit-stalk, or general spike.

- umbel Having the pcduncles subdivided into pedun cles of les. scr umbels, \&c.

- petiole. A divided leaf-stalk. - peduncle. A divided flower. stalk.

Cos'POUND TERMs. Whien any part of a plant is to be describ. ed, which does not agrec with the definition of any term in use; two or more terms must be com. pounded, so as to convey to the mind corrcet descriptions. For example, the chesuut leaf bas notches on the margin pointing towards the apex, which answers to the description of seratc leaves; excepting that the notches are hollowed out. But thesc hollowed notches are not decp enough for sinuses; thereforc the two terms are compounded, making sinuale-serrale. Compound terms are always unitcd by a hyphen.

Compres'sen, compres'sus. Flattened, as if squeezed or pressed.

Con'cave, con'carus. Hollowed a little on orse side. It is some. times applied to deeper bollows; though rarely.

Concepialculum See follicle, single-valved capsule.

Concrologr. The science of shells. It is divided into the Univalve, Bivalve, and Multi- 


\section{O R}

valve; which see-also see the terms, apex, base, front, back, sides, body, whorl, spire, aperture, lip, beak, operculum, cham. bers, siphunculus, slope, lunule, linge, ligament, cicatris, \&c.

Con'color. The same colour in all parts.

Conden'sED. See coarctate.

CONDU'PLICATE. That kind of foliation where the leaf, while in the bud, has its two sides shut together, like two leaves in a book.

Cone, colnus. See strobile.

ConfER't, confer'tus. Thick-set ; leaves, flowers, \&c. standing so closcly together, as to seem to crowd each other.

Con'fluent. Runming together. It is applied morc particularly tu the rcceptacles of some lichens, which run together in disorder, and become indistinct.

Conge'neres. Plants of very similar habits, \&c.

Conges'tus. See heaped.

Conglon'Erate. See glomerate. When used in geology, it is applied to aggregates of rounded pebblcs.

CoN'1c. With a broad base and ap. proaching a point towards the top.

Conif'era. Bearing cones.

CoN'Jugate. See binate. In pair's.

CONNA'TE. Leaves being opposite with their bases growing logether, so as to form the appearance of a single leaf. Anthers are sometimes connate also.

Consivent, Conni'vens. See converging.

Consim'ilis. Resembling.

Conlig'uus. Near, next.

Contin'vous. Uninterrupted.

CONTOR'TED, contor'lus. 'Twisted. It is also applied to corols, which have the edge of one petal lying obliquely over the next.

Conirac'lus. Close, narrow.
Contrairium. See partition.

Conver'ging. Approaching, or

bending towards each other.

Con'vex. Swelling out in a roundisli form.

Conrex'us. Convex.

Con'volute, convolu'tus. Rolled into a cylindric form, like a roll of paper, lengthwise with the mid-rib. Applied to the situation of leaves in the bua.

CoR ${ }^{\prime} \mathrm{CLE}$, cor'culum. (Cor, the heart.) The embryo of the new plant in a seed, situated between the cotyledons in dicotyledonous seeds. It consists of the plume and rostel, which show themselves soon after vegetation commences. Sec plume and rostel.

CoR'D ATE. Heart-form; so called from its supposed resemblance to the heart. It is bollowed behind with the side-lobes rounded at the base. See arrow. form.

CoR'DATE-OB'LONG, COR'DATELANCE'OLATE, \&c. partake of the formation of both compounds.

Conia'CEOUS. Leathery or parch. ment-like.

Cor'nered. Having angles or corners. Three-cornered, four cornered, \&c. is often expressed trigonus, \&c.

CoR'NAFORM. Horn-form.

Cor'nu. A horn or spur.

CoRnu'tr, Cornu'lus. Horn-form, or having horns or spurs.

Co'rol, corol'la. (A diminutive of corona, a crown.) The inner delicate covering of the flower, which constitutes its principal ornament in most cases. In it few cases, as the barlsia cocci. nea, the corol is dull and unsightly, while the calyx is gaily coloured. See petal and nectary.

Conol'zet, corollula. A little corol.

Corollif'erus. Bearing the corol. 
corol'linus. Resenbling, or appertaining to, a corol.

Coro'na. See crown.

Gorona'rizls. Forming a crown.

Corona'lus. Crowned; as the thistle seed is crowned with down.

Coro'nula. A little crown.

Cor'rugated, Corruga'tus. Wrinlcled. Applied also to ridges, ill some measure resembling wrinkles.

C'on'rcx. The bark, which see. It cousists of a uumber of layers equal to the number of years the thee las been growing; though they are often too thin to lie numbered. The inmost layer is called the liber.

Con'tical, CoR'ticate. Having its orivin from the bark, or haviug bark.

Cortina. Used by Persoon for a spiderwed-like valve, being very thin and filamentous.

Coryda'lis. (Kor'os, a helmet.) Plants with helmet.form corols. " 'o'ryais, Corymíbus. Flowers umbel-like in their general external appearance, but their peduncles or supporting stems stand at different distances down the main stem; as yarrow.

Corymbif'cra. Bearing corymus. Cos'tate, costa'tum. Ribled.

Cot'tony. See tomentose.

Cotylédon. See p. 6.

Cow'LED. IVhen the edges meet below and expand above, and generally separate; as the spathe of the arum, Indian turnip.

Cras'sus. Thick.

Cref'PiNg. Running along the ground, or along old logs, \&ct. nearly in a borizontal direction, and sending off rootlets.

Cre'nate. Scolloped, on the rim or edge. Notches on the margin of a leaf, whiclu do not point or incline towards either the apex or base. When large crenatures have smaller ones on them, they are doubly-crenate.

Cre'Nulate. Very finely crenated.
Cres'cent-rona. Resembling the form of the moon from it: change to half-fulled.

CIEST'ED. Having an appendage somewhat resembling a cock's comb in form.

Cre'ta. Growing on claalky land.

Cribrose. Sieve-like.

Crini'tus, Long-haired.

Cris'pus. See curled.

Cris'tate, Cristallus. See crest. ed.

Cross'-Armed, See brachinte.

Crowded. See confert.

Crown. The calycle, hair, or feathers on the top of some. seeds; as the dandelion.

Crown'Ex. See coronatus.

Cru'ciate. Cruciform, or lesembling the cruciform.

Crucialim. Crosswise. Oppo. site pairs of branclies or leaves successively crossing each other. See decussate.

Cru'clForu. (Crux, a cross.) Corols with four petals, whose lamina form a cross. Plants with such corols belong to the class tetradynamia.

Crusta'ceous. Leafy appearance, but consisting of small crusty substances lying oue upon allother.

CRY P'TOGA'MIA. (Kruplos, concealed; gamos, marriage.) Sec. p. 3,15 .

Cryptog'anous. (Kruptos, collcealed, gamos, marriage.) Belonging to the class cryptogamia. Applied to plants whose stamens are never inanifest under the highest maguifying power.

Cu'Bit. A measuse from the elbow to the end of the middle finger.

Cucul'late. See cowled. Hoodform, as the spathe of the Indlau turnip.

Cucurbita'ceous. Resembling gourds or melons.

Cu'linary. Suitable for kitchen cookery.

Cura, Cul'mus. The stem of gralu 
and grass, when dry it is usually called straw. It is applied to all grassy plants; as Indian corn, sedge, sugar-cane, \&ce.

Culmifisnows. Having culms, as wlieat, Indian eor'n.

Cularis'eous. Like the roof of a house. Top.

Cultrate. Coulter-form. The beak of a bird resembling a plough-coulter.

Cum'ulus. Heaped.

Cune'lform, Cune'iforme. See wedge-form.

CUP'-Fors. Hollow within, resembling a little cup.

Cupula. Cup. The pileus of a fungus, which is open at the top; as those of the genus Peziza.

Cupula'ris. Cup-form.

CURL'ED. When the periphery of a leaf is too large for the disk, it becomes waved or curled.

CuRv'ED. Bent inwards. See incurved.

Ciss. The bristle of a cuspidate leaf, calyx, \&c. Nuttall.

Cus'pidats. Eye-tooth. Having a sliarpened point and that tipped with a bristlc, a prickle, or lengthened apex, not curved See mucronate and observe the distiuction; also acuminate.

Coirres. The thin outside coat of the bark, which has no life and is very durable, often transparent. It greatly resembles the scarf-skin of alimals. Very distinct on elder, currant and birch; on one species of birch it resembles paper.

Cya'neus. Blue.

Cyalhifor'mis. Wineglass-form. Cylindric, widening gradually upwards, margin not rcvolute

CYIN'DRIC. A cylindrical sliaft, of nearly equal diameter throughout its whole extent.

Gymbifor'mis. See boat-form.

Gy in their gcneral external appearance. It agrees with an umbel in having its common stalks spring from one ecutre; but. differ's in having those stalks variously and alternately subdivided; as the elder, (sambucus.) Smith.

Cymo'sus, crMo'se. Being in cymes.

Cyphol'le. See pits.

\section{D.}

Dadal'eus. The end broad, waving and torn. Neatly formed.

DAGGER-POINTED. See cuspidatc. De'bilis. Weak, fecble, lax.

DEeris. Ruined rocks. The broken fragments of coarsely disintegrated rocks.

$D E C A G Y \mathcal{N}^{\prime \prime} / A$. (Deka, ten ; gune, female.) See p 13.

Decanorous. Plants having ten stamens in each flower.

Dechayhyl'lus. Ten-leaved.

Decem'fidus. Cut into ten parts, or 10-cleft.

Decemlocula're. Ten-celled.

Decid'uous. Falling off in the usual season for similar parts to fall; as leaves falling at the decline of the year; corols falling off at the time the stamens fall, \&c. See caducous and permenent.

DEcliens. Terminating.

DeCli'Nate, DeCLI'NED, declina'. tus. Curved downwards arch. wise.

Decomposition. Separating the chemical elements of bodies. It differs from disintegration, which subdivides without de* composition.

Decompoun'D, Decomposi'tus. Doubly-compound. IVhen a compound, or divided, petiole has a compound leaf on each part, the whole is a decompound leaf. The same with umbels, \&e. See supra-decompositus.

Decortica'bilis. Easily peeled.

DEсUм'BENT, decum'bens. When the base is erect, and the ro. 
mainder is procumbent. It applies to stems, stamens, \&c.

Decor'reat. When the two edges of a leaf extend downwards below the points of insertion and become projecting wings to the stem. The gills of agarics are decurrent, when they run down the stipe in a single ridge.

Dccursi've. Decurrently.

Decur'sively pin'Nate. When the leafets of a pinnate leaf run along the petiole with their extended bases.

Decus'sate, decussa'tus. When leaves or branches are opposite in pairs, and each pair stands at 1 ight angles with the next pair above or below on the same stem.

DEFLEc'TeD, deflex'us. Bending down archwise.

Deflora'lus. Having discharged the pollen.

Defolia'tion, defolialio. The shedding of leaves in the proper season.

Defolia'tio nu'tha. The shedding of leaves before the proper time, on account of injuries received.

Demis'cent, dehiscon'lia. The natural opening of capsules in the proper season.

Deliq'uium. See debilis. Weak, watery.

DeL'toid, delloi'deus. A leaf with four corners; that is, one at the stem, one at the apex, and one each side ; but the side ones are nearer to the base than to the apex. When the side angles are about as near to the apex as to the base, it is called a rhom. boid leaf. Both kinds are called diamond-form in English. Willdenow considers a deltoid leaf as a thick 3 -sided leaf, a transverse section of which he supposes intended, as giving the deltoid form.

Demer'sus. See submersed. Un. der water.
Dense, den'sus. Close, compact. A panicle with abundance of flowers very close is dense. See thyrse.

DEN'TATE, denla'tus. Toothed. leaf. (This term is of such almost unlimited extent, it is best defined negatively.) Projections from the margin of a leaf, which are of its own sub. stance; and not serratures, nor crenatures.

- rool. That kind of granulated root, which resembles teeth strung together.

Dentic'ulate. Having very small teeth.

DEN'TOID. Remotely resembling teeth, or having processes somewhat of that form.

Den'tulie. A tooth.

Denu'date. Plants whose flow. ers appear before the leavez, consequently have a naked appearance. Naked.

Deor'sum. Downwards.

Depaupera'lus. Few-flowered.

Depen'dens. Hanging down.

Depres'sed. When the upper surface of a succulent leaf is a little. concave. It applies to sceds also with flat tops.

Descen'dens, The entering of a root into the ground. The direction is verlical, as the beet; horizontal, as the mint; obliquc, as the branching roots of most trees.

DESCRIP'TIONS of plants. In writ. ing a complete description of a plant, begin with the fructification, and describe : 1. Calyx. 2. Corol. 3. Stamens. 4. Pistil. 5. Pericarp. 6. Seed. 7. Receptacle. Then go through with the root and herbage, thus: 1. Root. 2. Stem and Branches, 3. Buds, includin the Foliation. 4. Leaves. 5. The Appendages. 6. Inflorescence.

Then add the general appear. ance and size of the plant, and 
what weil known plant it most resembles. Give an account of the soil and situation where it grew ; whether high or low, wet or dry; the precise tine of llowering; colour of all parts; whether annual, biennial or peren. nial. Then close with the name of the town, county, Scc. and what quantity of the same kind of plant is to be found there; and what name the common people call it by, if any. Accornpany this description with se. veral specimens, so selected as to exhibit the plant in all its parts.

There can be no better exercise for students, than to write several such descriptions evcry day. See Diagnosis.

Desicca'tio. Dryness.

Desi'nens. Terminatiug.

1)ETRITUS. That part of the surface of the earth, which is neither rock nor recently decomposed animal or regetable matter. Ground or worn-down rocks in the state of soil.

Dexlror'sum. 'l'wining from left to right; that is, with the apparent motion of the sun; as the hop-vine.

DIADEL'PHIA. (Dis, twice; adelphos, brother.) See p. 14.

Dradel'phovs. Belonging to, or varying into, the class diadelphia.

Diagn,'sis. A short description containing only what is essential. Linueus made it his rule, never to let a specific description cxceed twelve Latin words. Willdenow says inore must be added if necessary. It should extend no farther than to express the difference between that and the other species.

Díamond-Form. See Deltoid.

DIAN'DRIA. (Dis, twice ; aner, male.) See p. 12.

Diaph'anous. Admitting the transmission of light obscurely. Iranslucent.
Dicnot'omous. Forked, Stem, \&c. parted in pairs, eacb branch parted in pairs again, and so on. When it is parted but once it is more properly called forked, furcalus.

Diclin'sa. (Dis, twice; klinc, bed,) stamens in one flower and pistils in another, whether on the same or on different plants. This is the name of a class in Pursh's Fiora, comprising most of the plants of the classcs Mo. nocia and Diœecia.

This class Pursh divides into three orders, 1, Segregato, which includes plants, whose flowers are monacious or dia. cious; but are not in aments or strobiles. 2. Amenlacea, which includes plants, whose flowers are in aments and not in stro. biles. 3. Conifera, which in. cludes plants, whose flowers are iu strobiles.

Diclinious. (Dis, two ; kline, bed.) Plants, whose stamens aud pistils are in different flow. ers, whether on the same plant, or on different plants.

Dicoc'cous. Two-grained. Consisting of collering grains, or cells with one seed in each.

Dicotrled'onous. Plants with two cotylcdons. See Cotyledon.

Div'ymous, di'dyma. 'Twinned, as some anters.

DIDYN AMIA. (Dis, twice; d 26 namis, power.) See 1. 13.

DiDYN'Amous. Belonging to, or varying into, the class Didyuamia.

Diffor'mis. Applied to a monopetalous corol, whose tube widens above gradually, and is divided into irregular or unequal parts. Willdenow. It is also applied to any distorted parts of a plant.

Diffracted. Twice bent. $\boldsymbol{\Lambda} n$ tennae are diftracted, when bent outwardly, then forward, at short turns.

DIFFU'SED, diffu'sus. Spreading. 
Cxpanded in an open loose manuer.

Dicitate. Fingered. When the base of several leafets rest on the end of one petiole; as the strawberry and fivefinger.

DIGYN/IA. (Dis, twice, gune, female.) See $p 16$.

Dilata'tus. Expanded, widened.

Dilu'te. Prefixed to a colour implies, that it is reduced. as dilute-purpureus, pale purple.

Dimidia'lus. See halved.

DIG'CIA. (Dis, twice; oilos, house.) See p. 15.

Dice'cruess, dioi'ca. Belonging to, or varying into, the class diceria.

Dipet'alous. Having two petals. DipliYL'Lous Having twoleares. Diptekyg'ia. See wings. Wing. ed seeds.

Dis'cord. Resembling a disk. A tuft of leaves spread out so as to resemble a disk Having a disk without rays. Such compound flowers as are wholly inade up of tubular florets; that is, though they may have marginal florets differing from thuse in the disk in the essential organs, yet the corols will be all tubular, and not eapitate.

DisintEgRATION. The process of destroying the integral charaeter of a body. Applied to geology it signifies, the process of crumbling down a rock, or re. ducing it to grains, pebbles or soil, by the two disintegrating agents, the variations of tem. perature and moisture.

Disk, dis'cus. The whole surfaee of a leaf, or of the top of a eompound flower, as opposed to its edge or periphery. This ter'? is also applied to the aggregate tlorets of an umbel, and to the broad or thiekened top of a receptacle. It is applied to the outer surface of each valve of a shell. Disper'mus. Containing but two
seeds.
Dissec'tus. Gashed in deeply.

Dissef'iatent, Dissepimen'lum. See partition.

Dissil'iens. A pericarp is dissilient, when it bursts open with a spring ; as the toueh-me-not, (impatiens.)

Distans. Standing off remotely.

Dis'ticially. See distiehus. This is a very odd adverb introduced by Nuttall.

Di'stichus. (Dis, twiee ; stichos, row.) Two ranked. When branclies, leaves, or flowers are arrantred aloug opposite sides of the stem or spike, so as to point two opposite ways; as the leaves of the hemluek tree, (pirtus canadensis.)

Distinc'tr, distinc'lus. Separate, op posed to connate or confluent Divan'zeate, divarica'tus. Branch. es spreading out from the stem so far, as to form more than a right angle with it above.

Diver'ging, Diver'gens. Branehes spreading out from the stem so far, as to form almost a right angle with it.

Diur'nus. Enduring but a day.

DIVI'DED, diri'sus. Severed into parts.

DODECAN'DRIA. (Dodeka, twelve; aner, male.) See fic. jeeted Classes.

Dodecan'drots. Belonging to, or varying into, the elass dode. candria.

Dodecaphyl'lus. Having twelve leafets.

Do'drans. Longspan. Distanee between the ends of the thumb and little finger, both being extended.

Dolabrifor'me. See axe-form.

DoR'Sar, dorsa'lis. Fixed to the baek. Back fins. Aivıs are dorsal, when proceeding from the outside of a glume and not from the tip.

Dorsif'ERous. Bearing the fruit on the back; as ferns.

DoT'TED. Besprinkled with dots. See punctate and perforated. 
DOUB'LE. TWo in the place where most plants have but one; as the double calyx of the hollybock, (althea.)

DOUB'LE-FLow'ERED. Sce full. flowered.

Dovn'Ly. See duplicate. In English it has its common appropriate meaning; as doubly-crenate, when the crenatures are crenated, \&c.

DoUB ${ }^{\prime} L Y-P I N^{\prime} N A T E$. See bipinnate. Down or Down'y See tomentose. Droop'ing. Sec cernuus.

DruPE, drup'a. That kind of pericarp which consists of a thick, fleshy, succulent, or cartilaginous coat, enclosing a nut or stone. It is bcrry-likic (baccata) as in the cheriy, or dry (exsucca) as in the walnut (juglans.)

Drupa'ceous. Bearing drupes, or fruit resembling them.

Druses. Any cavities in minerals, which are lined with crystals.

Dublius. Doubtful.

Dul'cis. Sweet.

Dumo'sus. Busby, or resembling bushes.

Duodeccm'fidus. Cleft in 12 divisions.

Du'plcx. Double.

Du; lica'lo. Doubly. This term is often prefixed to others, in all whiclı cases it simply means doubly. As duplico-ternatum, doubly-ternate or biternatc.

Duplica'lus. Doubled.

DURA'Tion. See ages.

I) $\mathrm{x}$ AMOUS. Applied to plants whose flowers contain two, or four, stamens, longer than two others in the same flower.

\section{$\mathbf{E}$}

LAR'ED. This term opplies; 1st, to the round extended, or appendaged lobes of a heart-form lcaf : $2 \mathrm{~d}$, to the side lobes near the base of some leares : and
$3 \mathrm{~d}$, to twistcd parts, in some ferns and some liverworts, which are supposed to resemble the conchus, or passage into the ear. Applied to shells, it means the flat processes near the hinge in bivalues; as the pecten (scollop.)

Ebractea'lus. Without bracts.

Ebur'neus. Ivory white; as the whole plant monotropa, called beechdrops, or birdsnest.

Ecalcara'tus. IVithout a spur.

Еспі'Nate, china'tus. Hedgehog-like. Beset with erect prickles.

Ecos'tate. Nerveless or ribless. Erflores'cence. The powdery substance on some Lichens, composed of minute deciduous globules.

Effloresccn'tia. Flowering season of lifferent sorts of plants. More simple flowers come out in June tla in any other month, in North America. Very few compound flowers appear before August.

EFFolia'tron. Unnatural falling of leaves by means of improper culture, worms, \&c.

Erfuse. Open, or having an opening, so that seeds, liquids, \&cc. may be poured out.

EgG'-Forss. See ovate.

Eglandulo'sus. Glandlcss.

Egret. See aigrette.

Eras'tic. Sec dissiliens. Spring ing.

Er,p Tic. Longer than wide, rounded at or near both ends, and nearly equal in breadth to. wards both base and apex.

Elon'Gated. Lengthened out, as if extended beyond what is usual in similar parts.

Elytra. The otuter, or upper, shelly wings of some orders of insects.

Emar'cidus. Sce withering.

EMAR'GIvate. Notched in the end at the termination of the midrib, Sce Retuse, 
EimBRA'CING. Sec clasping.

Eumbron. See hilum. Eye of a bear, \&c.

Camensed. Out of water.

Fimpllement. See calyr.

END'-Bitten. See pramolsus.

JiER'vate. Nerveless.

ENNEAN'DRIA. (Ennca, nine; aner, male.) Sec p. 13.

Exvean'drous. Belonging to, or varying into, the class cnncandria.

Enncapet'alus. Nine-petalled.

Eno'dis, ENo'de. Knotless. Having no joints; as the bulrush.

En'sate, cnsatus. Haviıg swordforn leaves.

E.s'siform. Sword-form. Twoedged, tapering from base to atpex mostly, and a little arch. ing towrids one edge; as flag

and cat-tail, (Iris and Typha.)
ENT'rs. Continued without interruption. A margin of a leaf, calyx, corol, \&c. is entire, when it is neither serratc, toothed, notched, nor in any manner in. dented.

Extomology. The science of insects. It embraces the whole articulated division, excepting Aniselida.

Ephc'merus. Of very short duration.

Epicar'pens. On the germ. See superior.

Epider'mis. See cuticle.

Epiphray'ma. A thin membrane stretched over the mouth of the moss, polytrichum.

:'quaL. Similar parts equal among themselves. The calyx, corol, \&c. are equal, when the are similar in form, size and direction. Opposed to unequal.

Lquinoc'tial FLOW'ERs. Opening at stated hours each day.

EQ'vitant. Opposite leaves embracing each other, so that they alternately enclose each other's edges; as the leaves near the loots of the Iris and yellow gar. den lilies, (hemerocallis ;) also the position of the leaves in soine unnpened buds.

EREc't, erce'tus. Upright. Not so perfeetly strait and unbending as strictus. When applied to any thing laterally attuched to the stem, as leaves, \&c. it implies that it makes a very acute angle with it.

Ercctius'culus. Erectish.

En'Got. See spurred rye.

Erina'ccous. Hedge-log-like.See cchinatus.

Ero'se, cro'sus. Gnawed. Un. equally sinuated, as if the sinuses had been eaten by insects.

Es'culent. Eatahle.

Eschtrifen. A plate betwecu the bases of wings of insects.

Essen'tial character. See diag. nosis.

Essen'trals. The stamens and pistils.

Ev'ergirens. Such plants as retain their leaves throughout the year; as white pine, lanrel, \&c..

Ev'ergrean. Verdant througliout the year.

Exan'nulate. Ferns whose capsules are without rings. 'This comprises olle section of ferns. Those which have an apparent vestige of, lut not in reality, a ring, form another section. Those with a ring, a nother. See annulatus.

Exara'lus. See sulcate.

Exaspcra'tus. See roughened.

Excavalus. Hollowed out.

Exot'ic, exot'icus. Plants not growing spontaneously in a wild state in that particular country, or section of a country.

EXPAN'DED, expan'sus. Spread. ExPANille. Capable of being
spread.

Explana'tus. Uufolded. Spread

Exsert', exser'tus. Standing out. Stamens are exsert whel protruded out of the corols. Pe. duncles of spikes in culmiferous 


\section{F I B}

plants are exsert, when protruded out of the sheaths; as carex folliculata and pubescens. Teeth may be exsert.

Exstip'ulate. IVithout stipules. Exsic'cus. Juiceless.

Ex'limus. At the very top, or extreme end.

Extrafolia'CEOUs, Outside of the leaf. A stipule is extrafoliaceous when it comes ont a little lower than the leaf does. Extrors'um. Outwerdly.

Erv. See hilum.

\section{F}

Fac'ies. The general external appearance of a plant.

Factitious. Produced by art ; not natural.

Factit'iovs character A character, where the number of parts or some other circumstance, not of essential importance, are taken into it. It admits of fewer or more characteristic marks, than are absolutely necessary.

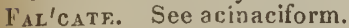

Fam'rilies. Seegentes.

FAN'roRM. Spread out, or tapering towards the base like a fan.

Farc'lus. Stuffed, full. It is opposed to fist.llous, hollow.

Fari'nn. See pollen Meal, flour.

Farino'sus. Mealy, powdery.

Fascia'tus. Having parallel bands, or coloured stripes.

Fas'cicle, fascic'ulus. A bundle. Flowers level-topped, umbellike in the general external appearance, with footstalks irregular in their origin and subdivision. The fascicle differs but little from the corymb, excepting in having shorter footstalks, which do not extend so far down the inain stem. Sweet-william (diantlus) is a good example.

A bundle of tuberous roots is called a fascicle; as the asparagus roots. Also a bundle of leaves; as of the white pine.
Fascic'ulate. An unnatural bundle of branchlets.

Fastig'iate, fastigia'tus. Level. topped. Applied to aggregate nowers, which are elevated to an equal heiglit or nearly so ; forming a level, convex, or concave top, differing but little from a plane. It is also appliert to leaves; as the hog-weed (am. brosia artemisifolia.)

Favo'sus. See alveolate. Resem. bling hon ey -comb.

Faux. Jaws The throat or opening into a corol. That precise spot, where the tubular part of a ringent corol begins to separate or expand into lips or month, is the faux.

Fratilier. See Aigrette. The plumose crown of seeds.

FE'MALE, femin'eus. See pistil. late.

FENCE. Involucre of Withering. FEn'CED. Walled around, as the stamens are by the scales in brookweed (samolus.)

$\mathrm{Fe}^{\prime}$ re. Almost.

Ferss. Set filices.

Ferriferous. Containing iron.

Ferr'uginous, fcrugin'eus. The colour of iron-rust. Applied to masses of minute quartz crystals.

Fer'trile. See pistillate.

Fertiliza'tion. The application of the pollen, which is formed in the cells of anthers, to the stigma; which is essential to the production of perfect seed. See chorion. Richard is too lengthy unon this subject for the plan of this Dictionary; which is intended for definitions and illustrations, but not for physio. logical discussions.

Fettered, Having entangling featluers on or near the legs.

Fi'Bre, f'bra. Any thread-form part The small flexible threadform roots of grasses and many other plants, are called fibres.

$\mathrm{Fr}^{\prime}$ brous. Composed of fibres, 


\section{F $\mathrm{L} O$}

F:D'DLE-FORS. Sce panduriformis.

Figu'va. See Icones. Figures, drawings.

Figura'tum. This term is applied to the mouth of the capsule of a moss, when it is set round with membranaceous teeth.

Fil'ament, filamen'tum. That part of the stamen which is between and connects together the anther and the receptacle, calyx or pistl. When the filament is wanting, the anther is sessile. In mocopetalous corols, the filaneuts are generally inserted into, or are attached to, their bases.

VIL'ICES, FERNs. See p. 18.

Fin'lifóm. Thread-like. OI nearly equai thickness through . out, round and cylindric. It is applied to spikes which are very long in proportion to their diameters. But it is generally confined to smaller parts.

Fimbria'tus. Fringed. Differs from ciliate in being less regular and of coarser parts.

Fimcla'rius. Growing naturally on manure heaps.

Fin'Gered. See digitate.

Fissıle. Easily split in the direction of the laminae.

F'is'surv. A cleft or slitted apperture.

ris'sus. See cleft.

Fis'ruloos. Hollow like a pipe, flute or reed.

Elab'ELLIFora. See fanform.

Flac'cid, flac'cidus. Too lax or limber to support its ow n weight. See lax.

Flagel'lum. See runner.

Flagellifor'mis. Resembling a whip-lash.

Flam'meus. Flame-coloured.

frar. See planus.

Ela'vus. Yellow.

Fuesh'y. Thick and filled with pulp within.

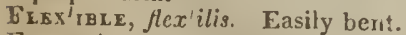

Ezexvo'se. Bending and frequent. ly changing direction. A stem is flexucse, or zigzag, which uni. formly bends at regular intervals ; as from joint to joint, branch to branch, leaf to leaf, dec.

Flex'us. Eent. This relates to but one bending. See geniculate.

Frónting. See natant.

Flocco'se. Woolly, or resem. bling the llucks sheared from cloth.

Flo'rat. Relating to a flower.

- bud. Containing an unopened flower.

-la:r. See bract

Floresecn'tia See eflorescentia.

FLo'RET Little foower. Whiether the flower is large or small, it is a floret, if it is one of number all of which constitute an ag. gregate or compound. As the little flowers which make up the head of a thistle, a head of wheat, the umbel of a carrot, \&c.

Floribun'dus. Abounding in flowers.

Fronir'srous. Bearing flowers. A leaf is floriferous when a flower grows out of its disk or mar. giı.

Fro'Rist. One whose employm is that of creating monsters; that is, double and various co. loured corols; as carnations, double roses, dic. Thesc ineet a inore ready sale than the most interesting plants in their native state, among persons of a coarse unscientific taste. Such persons, to be consistent, should prefer the high coloured danbings of a sign painter, to the delicate touches of a Savage, a Trumbull or a Vanderliı.

Flos See flower.

b los'cular, flosiulo'sus. See tubulous.

Floscu'lus. Tubular floret. Nuttall applies it to the florets of grasses; but ought not to be follorred. 
Frow'er. The stamens and pistils with their covering. These two organs, or rather their anthers and stiqmas, arc essential to all plants. But the calyx, corol, and even nectaries when present, are parts of the flower.

Flow'zing SE'Ason. Sce efflorescentia.

Flow'Elr stark. See peduncle.

Fluvia'tilis. Growing naturally in rivers and bronks

Fe'tidus. Smelling disagreeably. Fold Anuexed to numerals denoting so nften cumbined; as 5 fold leaves, growing in fives, drc

Folia'ceous. See leafy.

Foria'ris. A tendril on a leaf:

- gcmme. A bud contaising leaves only.

Foum'tes, foltatio. The manner in which unnpened leaves are situated within the bud. The modes of foliation are: 1 . Involute. 2. Rivolute 3 . Obvolite. 4. Convolute 5. imbricate. 6 . Equitant. \% Conduplicate. 8. Plaited. 9. Reclinate. 10. Circinal. See each in its proper place.

Folia'tis. Leafy

Folif'crous. F'articularly adapted 10 berring leaves.

Fol'iole, foli'olum see leafet. One of a compround leaf.

Folio'sus. See leafy.

Fol'ium. See leaf.

Fol ${ }^{\prime}$ icle, Folicu'lus. A pericarp with one ralve, which opens lengthwise on one side only; as inilk-iveed (asclepias.)

Fontina'lis. Growing naturally about springs.

Foot'stalk. See poduncle and pctiole, it is put for both.

For.'men A hole.

Foraminulo'sus. Pictced with many small lıoles.

Fork'ED See dichotomons

Formation. A term used by geologists to express more or less than a definite stratum: as detritus is called alluvial forma. tion, iron formation may apply to the fcrriferous rocks and their iron contents.

Fornicaltus Arched. See vault. ed

Fon'cu. A nectariferous cavity for the reception of lioney. Honey-comb like.

Fovil'la. The fine substance con. tained in the particles of pollen. When the ripe pollen comes in contact with the moist stigma, it explodes and discharges the fovilla.

Frag'ilis. Breaking easily and not bending.

Frer. See libera.

Freq'uens. Very common, or fre. quent.

Fri'gillus. Growingr naturally iu cold countrics.

Frin'GED. Sce firnbriatıs.

Froñ An herbaceous, a leathery, a crustaceous, cr gelatinous leaf, or someivhat of a leaf-like sulistartce, from which or witls. in which the finit is produced. It is applicd exclusively to the class cryptogamia-Smitlı, But formerly it was also applied. to palms.

Frondescen'tia. See leafing.

Frondo'se, Frondo'sus. Leafy, or leaf-like. It is applied to mosscs to distinguirs them from liveruorts by Willdenow ; who retains them in the same order.

Frons. See frond.

Frontlett. The part back of the base of a bird's bill. Gellerally bristly.

Frutescen'tia. Applied to palms and such others as have a simple stcm, and leaves only at top. Willdenow,

It is applied by Martyn to the time wlicn vegetables scatter their ripc seeds.

Fructif'ernus. Bearing, or becoming, fruit.

Fructifica'tion, Fructificalio."The temporary part of vegctables, which is destined for the 
Leproduction of the species, termimating the old individual and beginning the new."-Linneus. It consists of seven parts-1. Calyx. 2 Corol. 3. Stamen. 4. Pistil. 5 Pericarp. 6. Seed. 7. Receptacle. See each in its proper place.

Fruit, frucllus. The seed with its enclosing pericarp. If the seed grows nakcd, the sced alone is the fruit ; as of the sage.

Fruit'-inots Ascemblages of capsules on the backs of feriss. Also small assemblages of powdery bodies on the fronds of liclieus, called sorcria.

Frivit'stalk. Sec peduncle.

FRU,$T R A$ NEA. (Irustra, in vain,) polysamia. See p. 18.

Frutrs'CENT, frutes'cens. Woody; or from herbaceous becoming woody.

Frut'ex. A shrub, which see.

Frutico'sus. Sce shrubby.

Fug'ax. Fugacious. Soon disappcaring. Flyins off. See ring

Fulcru'tus. Having appendages.

f'ul'crum. These are seven-1. Stipule. 2. Bract. 3. Thorn. 4. Prickle. 5 Sting. 6. Gland. 7. Tendril. See each in its pro. per place.

Fuliginers. Sooty, dark dull colour.

Furl-fuowered. When the petals of the corol are so multiplied as to exclnde the stamens; which is effected by the stamens becoming petals; as the peony, rose, \&c. This rarely takes place in monopetalous corols. Double flowers arc totally unfit subjects for botanical exerciscs. See flurist.

Fun'vous, Ful'rus. Yellowish, rust-colour.

FUN'GI, funguses. They are now known to be organized bodies, propagating their kind by seeds, like other vegetables. Howevel unsightly a eommon toad- stool, the mould on old seraprs of leatlier in damp places, or the blight in grail, nuay appear to the careless observer; they are all beautifnlly organized, and hishly interesting to the student in Natural History. But "their sequestered and obscure habitation, their short duration, their mutability of form and sub. stance, render them indeed more difficult of investigation thau crimmon plants."-Smith. See p. 19 \& 25.

Funco'se. Flesliy and spongy.

Fun'sus. This term is sometimes put for pitens.

Fu'Nicule, Funic'ulus umbilica'. lis 'The thread by which a seed is fastened at the hilun.

Fun'net-Form A corol with a tubular base, and a border opening gradually into the form of a reversid cone.

Furca'tus. See dichotomous.

Furfuraceus. Bran-like.

Fur'Rowed. See sulcate.

Fus'cres. Sooty-yellow, dark-yellow.

Fu'siform, fusifor'mis. Spindleform. A ront thick at the top and tapering downward to the point is fusiform; as the bcet and carrot. A worm, larra, shell, \&e. may be fusiform.

\section{G.}

Gal'ea. See labiate. A helmet. Ga'Lfate, Galea'tus. Resembling a belmet.

Gatls, Gal'la. Excresences pro. duced by the stings of insects. The balls found on oaks which are used in dyeing, the common large green oak-balls, the singular green lumps lound on the wild honey-suckle, \&e are examples. The irritation upon the delicate sap-vessels, pro. duced by the sting and egg of the inseet, eauses a greater flow of sap in that direction. This 
pressurc of sup distends and distorts the capillary tubes and nembraucs, until those excresences arc formed around the egg In due time the egg becomcs a larva, or maggot, which aftcr feeding a while upon the gall, changes into the pupa, or chrysalis, and at last escapes a perfect insect, or liy. Each fly produces a gall of a peculiar form.-IVilldenow.

G.INGUL. The pari of a rock which lines a vcin aud embraces a mineral, and is unlike the rest of the rock.

Gixs. The opening between two lips of a iabiate, or irregular, corol. Applied to mouths of birds.

GAP'ING. Sec hians.

GAs'HED. Sce incisus.

Gem'inus. See double. It is also $\mathrm{used}$ for paired, in pairs or $t$ wins.

Gem'ma. See bud.

Gemmalio. Budding. The gemmation of plants comprehends the developement of a new plant from the bud, as well as the foliation; according to Richard. See foliation. Buds are of four kinds. 1. Bud, properly so called, whicl see. 2. Turion, the radical bud, or tender shoot which rises from the root in the spring, bcfore it expands its lcaves; as the early asparagus slioots. 3. Bulb, which see. 4. Propugo, a longish round body proceeding from the mother plant in mosses, which itself becomes a new plant. This is placed among the buds by Richard: but Linneus calls it the sced; and Gærtner applies it to the seed of lichens also.

Gemir'arous. Producing buds in the axils of leaves.

Gen'eral. See partial.

GEN'ERAL FENCE. Universal ill-

volucre.
GinsR'1C cIAR'ACTER. The definition of a genus. It is confin. ed cutirely to the flower and fruit. It is essential, factitious, or notural ; whiclı see.

Gener'ic Name The name of a genus. Mlilne enumerates 21 rules respecting the naming of genera; which with his examples, occupy 40 pages. The principal names arc founder upon sonie supposed virtues of plants, expressed in Latin or Greck-the habit, place of growth, \&c. expressed in the same manner-given in honour of some distinguished botanistor borrowed from the fables of poets.

It seems to be an establishcd modern rule, that no genus shall havc the name of a politican, or of any other character however distinguished, unless liberal patronage, or skill in the science of botany, will warrant it.

Genic'ulate. Kueed. Forming a very obtuse angle, like a moderate bending of the kuee.

Gen'tes. Nations. Linneus divid. ed plants into nime great natural tribcs or casts. 1. PALus (palma;) as the date and cocoa-nut. 2. Grasses (gramina;) as wheat, Indian-corn, sugar-cane, rice, timotlıy-grass, \&e. 3. LiLies (lilia ;) as lily, tulip, daffodil, \&c. 4. Herss (herba; ;) as thistles, nettles, peas, miut, potatoes, hemp, plantain, beets, and all other herbaceous plants except the above. 5 TREES (arbores;) as oak, chesnut, pine, willow, dogwood, currants, lilac, whortleberry, cranberry, and all other plants with a woody stem. 6. FenNs (filices;) as brake, polypod, maidenhair, ground pinc, and all other plants of this order, which sec. 7 . Mosses (musci.) Soe the order. 8. Alge. This tribe includes the plants of the orders, hepati$c a$, ulge and lichenes, which see. 9. Fuxal. As mushroom, toad 
stool, puff-ball, inoulá, blighi, Sie.

(r.'Nu's, (plural gen'ora.) A number of plauts which agree with onc anotler in the strucfure of the flower and fruit.--Willdenow. The classcs are divided intu orders, and then the orders arc divided into gencra, the gencra into species. This is the analytic method. The species arc united into their respective gen cra by rejecting the specific distinctions; genera are uuited into thuir respective orders, by rejecting tle gencric distiuctions; urders are united under their respective classes by rejecting the faxinal character. Fins is the synthctic method. Thus it will lie readily perceived, that scientific botany is practical logic.

Plants of the same genus poscess similar medical powcrs, though iu very diflerent de. grees.-Milne. This rule is certainly liablc to some exceptions.

lisons. A cavity in a mineral whose sides withill are more or less spherical. It may be empty, or may contain mimerals differeut from the mineral containing the geode.

(iERM, gerinen. That part of the pistil, which, after the pollen is reccived, soon contains the rudiment of one young plant, or more. Its whole substance becouses the pericarp and sec $d$, as it enlarge sitself.

When the calyx comes out be. low the germ, the germ is supe. rior, and the calyx inferior; when the calyx comes out of the IIpper part of the germ, the germ is inferior, and the calyx superior.

The mirabilis and sanguisorha, have the germ between the calyx and corol. But Smith ays, the corol can be traced to the base of the germ in the sfurguisorba; and the mirabilis (called the four-o-clock) inay be treated in the same manner. It is therefore very doubtful, whether there is a plant, whose germ is becwecn the ca. lyx and corol.

Ger'minate. Apperiaining to the germ.

Girminatron. The sivclling of a seerl, and the unfolding of its embryo.

Gin'Bous. Bunched out. Whicn one or both sides arc swelled out.

Gu-covers. The bony or cartilginous coveriug placed over, or outside of, the gill-menbranes.

Gith-membranes. The meinbranes immediately covering the gills.

Gicis.s. See lamella. Limgs of fish Gil'tus. Iron-grey, and Lrick-colour.

Glabel'lus Baid IVithout hairs. GLA'BRous, glab'er. Sleek. Has: ing na pubescence. Gluber is often translated smooth, which in most cases coliveys a correct idea ; or at least does not lcal to error. But a leaf with soft coltony jubescence is sniontl, though it is not glabrons.

Gladia'lus. A sword-form legumc is sometimes called gladiatc Sec ensiform.

Gland, glan'dula. A round, or roundislı appendage which serves for trauspiration and sccretion. They are situated on leaves, stems, calyxes, and par'ticularly at the bace of stamens in some cruciform flowers; as mustard. Glandular hairs, or hairs with glandular heads, arc very abundant on the common hazlenut calyx, of North Ameri ca, (corylus americana.)

Glan'dular, Glan'dulous, glan. dulosus. Having glands.

Glandulif'Erous. Beariug glands. Guas'-1ory. Sec eyathiform. 
Cilas'sy. Sec byaliuc.

Glav'cous. Clothed with a seagreen mealiuess, which is easily rubbed off. It is sometimes put for a greenish-yrey colour. Ihis colour, ferruginous and huary, are so constant, that they are: used in specific descriptions. All other colours are excluded on account of their being too variable to be relied on.

Gr.oвo'sf, Globo'sus. Spherical, round on all sides like a ball. This term is often applied in cases where the part is rather roundish than perfectly globular.

GloB'ules. That kind of receptacle of lichens, which is globose, solid and crustaceous, formed of the substarice of the frond, and terminating its points or branches; from whence they fall off entire, leaving a pit or cavity. They are supposed to be covered all over with a coloured seed-bearing membrane. Smitll.

Glob'uli. Globules.

Glo'chis. See barb.

GLork. A roundish head of flowcrs.

GLon'ERATE, glomera'lus. When maily branclilets dre terminated by little lieads.-Richard. A spike is glomerate when it consists of a collection of sperical heads.-Willdenow.

Gron'Enulf, glomeriulus. The small heads coustituting a glome, or a small glome.

GLvis'ceous. Glume-like, or bearing glumes.

Ciccme, glu'ma. Consists of the scales of chafls which surround or enclose the stamens and pistils in the flowers of grasses. The lower ones are called the caly $x$, all others the corol.

Each scale, chatf, or husk, is called a valve; which gives the stames bitalce, with 2 busks or chafts; univclue, with one, \&c.

When several flowers are arranged along a rachis in a spikelet with a valve or two, or more, below the lowest flower, these are called the common or general calyx (gluma communis ;) and the glume to each floret on the spikelet above is called partial (gluma partialis.)

Richard says, glumes ought to be called bracts; as they are not properly either calyx or corol.

Guvmo'se. Having glumes.

GLu'tinous. Having on some part more or less of adhesive moisture.

GNAW'ED. See erose.

Gongrlous, Gon'gulous. A knot. lt is applied to a round, hard body, which falls off upon the death of the mother plant or animal, and becomes a new one; as in the fucus and some radiated animals.

Gonor'terides. Angle-fruit fern. One of the new orders of ferns. It is adopted by Pursh, Torrey and a few other writers on American botany. The receptacles of the fruit are polygons; as of the genus Equisetun.

GRAM'INA. 'The family of grasses. See gentes. But in a limited sense, the sedges, rush-grasses, \&c. are not included. See Natural Orders. Culmiferous is the most entensive term; and most of this vast family have three stamens in each flower, though many of them are monoecious. The rice, star-grass and rush grass have six stamens to the flower.

Graminifol'ius. Having leaves resembling those of grasses.

Grandiflo'rus. Having large flowers.

Granif'erus. Bearing grains or keruels; as those on the valves of dock-flowers.

Gran'vlate, granula'tus. In the 


\section{H E M}

form of grains. A granulate root consists of several little knobs strung together along the side of a tiliform radicle. It differs from the knobbed tuberous roots in this; that the latter are strung together by rootlets which proceed from near the middle of one knob to auother.

Granula'tions. Grain-like substances.

Grave'olens. Having a stroug odour or scent.

Gregarious. In flocks. Applied to fungi and other plants growing together in groups; but not so as to be crespitose, or to form a turfy mass.

Gressoral. Birds' feet, which are formed for running; having three toes forward and one back, and the two outer toes mostly joined towards the base.

Groov'ed. See sulcate.

Grossifica'rion. The enlarging of the fruit after the florescence.

GUITAR'-ForM. See panduriformis.

Gymnocar'pi fun'yi. Such as bear seeds in a naked hymenium, which see.

Giymnosper'mus. (Gumnos, naked; sperma, seed.) IVith seeds naked, or growing without pericarps.

Gyandrous. (Gune, woman; aner, man.) Applied when stamens grow on pistils, but not in immediate counexion with the calyx or corol.

\section{II.}

Ulabia'lio. The native residence of plants; or the situation wherein they grow most naturally.

HAB'1T, hab'ilus. The external appearance of a plant by a general view of which we know it without attending to any of its essential characters.

A knowledge of the babits of plants is to be acquired ; by first seeing them in a growing state, and then by repeatedly reviewing them in an HERBARIUN, which see.

HaIr. See pilus.

HAIR'-LIKE. See capillary.

HaIR' $\mathbf{x}$. See pilose.

HaL'bert-forns. See hastate.

Halters. Globules on slender stems under the wings of some two-winged insects, called poi sers.

Halv'ED. One-sided, as if one half had been taken off; as the halved spathe of some Indian. turnips, one-sided involucres, \&cc.

II 'mus. A hook, as the hooked spines on burdock.

Ilamo'sus. Hooked.

IIamulo'sus. With very smal! hooks.

HAND'-Form. See nalmate.

HANG'ING. See pendent.

Has'TATE. Halbert-form, or shaped like an espontoon. A leaf with processes near the base from eachedge, which are acu. tish ; as coinmon sorrel leaves. When these processes point con. siderably backwards the leaf is sagittate.

Hatch'et-ForM. See axe-form. Head. Flowers heaped together iu a roundish form with no peduncles or very short ones ; as clover-heads. This term is applied to a globular stiguna also.

HEA $P^{\prime} E D$. Compact, but hardly so close as dense.

Heart. See corcle.

Heart'-Form. See cordate.

HEDG'E-HOGged. See ferinace. ous.

Hel'aet. See labiate. Upper. lip.

HELMiNTHology. The science of of worms, including molluscous and radiated animals.

Helvolus. Pale red. Peach. bloom.

Hea'sspuere. Half a sphere. 
HEPAT'ICA. See cryptogamia. Liverworts, p. $19 \& 26$.

HEP'TAGYN'IA. Seven-styled. HEPTAN'DRIA. (Hepta, seven ; aner, male.) See p. 12 \& 17. Seven-stamened.

HEPTAN'DRoUs. Belonging to, or varying into, the class lieptan. dria.

HERB, her'ba. Any plant which lias not a woody stem. But when applied to the nine families (see gentes) it includes neither grasses nor lilies.

Herba Ceous. Not woody. Also applied to plants which perish anuually down to the root.

11EPB'AGE. All that part of vegetables which is bounded by the root below, and by the fructification above. It comprises all parts of every plant, except the root and fructification, whether lierbaceous or woody. See partes.

HERBA'RIUM. A collection of dried plants. No person can ever become a good practical botauist without an herbarium.

The uses of an tuerbarium are principally these;

1. To revive in the memory the names and habits of plants. No memory is sufficiently retentive to permit nothing to slip, relating to several hundred species of plants; unless they are frequently presented to the eye.

2. When planls are not in flower, they often want some of their most striking habits also. It is therefore very convenient and satisfactory to compare the more minute parts, in order to insure correctness in relation to plants, which we lave occasion to examine at various seasons of the year.

Directions for making an herba. rizm.

1. Provide yourself with apout 100 old newspapers; or other coarse paper about equal to that in quantity and texture. Let these papers be very thoroughly dried. This will be a sufficient stock for the season.

2. Procure two smooth inchboards of the size of half of a paper; also a weight of lead, stone, or other substance, of twenty pounds.

3. Gather 3 or 4 specimens of each plant, as it comes in flower. If you collect but few specimens, and wish to preserve them in the most beautiful form, put them between the leaves of a port folio in the field. Let the specimens be so large as to in. clude the various parts of the plant. If it be a small plant, take the root also. If large, take it in two pieces; one to include the flower and parts adjoining, the other the root-leaves, if any, and those near the root. Place these between the folds of the papers, as nearly in their natu. ral state as possible. If the plant curved, let it curve in the papers; if the flower drooped in the field or woods, let it droop in the papers, \&c. Lay the pa. pers between the boards with the weight upon them. If 20 or 30 filled papers lie upon each other, it is all the same.

4. Twice or three times each week lay your papers, containing plants, separately in the sun, with small stones on the corners, for three or four hours. When taken in, put the plants in press again. This exposure to the sun is not necessary, however, with single specimens of small plants. Or if several leaves of paper be allowed to eaeb specimen.

5. As fast as your plants become dry by absorption, put them up in books made of the same paper, with about a dozen sheets in each. Most plants will be 
alt to pat up, after sumning the prapers live times, and pressing ivo weehs. When the roots are taken up, if butbous, they should be split and immersed in boilng water, or they will be very long in drying. Miost ever-grcens and succulent plants, except aguatics, should be iminersed in hoiling water, or they will drop their finwers, Scc.

6 After the season is past, (which is about the cud of Noveinber.) make a large book of stiff priating pape:; aud fisten one or mole of your best specimens of each species to the first prage of each leul. Put as mauy specimens on a leaf as will fill it up ; leaving room for names, dc. under each. Some glue thein ou; others cut through the papers and raise upslips, like loops, and run the specinens under these loops. The latter method is best and cheapest.

It may be proper to observe, that if a long season of wet weather occur, or if you liave not time or convenience for drying your papers in the sun, you may efiect the same object by drying other papers thoroughly by a fire, and then shifting your plauts into them.

Plants should never be dried so as to become brittle. The ubject in drying them between papers is ; to prevent their crisp. ing, to make them tough, and to retain their na ural colour and texture. But still many plants cannot possibly be made to retain their natural colours.

Simple and woods flowers abound in the fore part of the season; compound and fietd flowers come inost after the middle of July. An iudustrious collector will have 400 species by the first of July; aud 250 speries afterwards, before the season closes.
Herbalius. An lierbist. One who collects andi sells plants.

Henua pu'nodite. See perfect Hower.

IJixag'ona, hexago'mus. Sixcornereal.

HI:XAGY $Y N^{\prime \prime} I A$. (Her, six ; gune, femate.) see $\% 16$.

IIEXAN'DRIA. (IIex, six; ancr, inale.) See p. 12

Hrxin'urous. Belonging to, or varying into, the class hexandria.

IJt:xaprit'atous. Six-petalled. Hexapclaloides. A one-petalled corol so deeply divided as to appear 6-petalied.

Ilexaphyl'lus 6-leaved.

II'ans. See gaping.

Hi'Lua. The exterual scar or marh on a seed, where the tinnicle, or thread, is attached to it and con. veys its nutrimeut till ripe.

Hinge. The part of a bivalve shell, where the two valves are united by a flexıble cartilage.

Hinsu're, hirsu'lus. Rongl-baired. Covered with stillisli lsairs, but hardly stiff enough to be called bristles.

Hir'tus. Covered with short stiff hairs Nearly the same as hir. sute.

His'pid, IIis'pidus. Bristly. Beset with stiff hairs, or rather with bristles, which are very short. Perhaps it differs from hirtus ouly in having the hairs shorter and stiffer. It seems to be ap. plied in some cases, however, where the bristlus are not very short.

Hiuleus. Cracked open ; a gaping chiuk.

Ho' ARY. Whitish colonred, aris. ing from a sealy mealiness. See glaucus.

Holera'crus. Suitable for a potherh.

Hor'Lows, (thalamia.) That kird of receptacle of lichens, which is spherical, nearly closed, lodged in the substance of the frond, 
lined with its proper coat, under which are cells 2 ol $^{\circ} 4$-seedcd. Each hullow finally operis hy an orifice in the surface of the frond above.-Smith.

Hon'EY-CUP. See nectary.

Hoon're. See cowled.

llook $\mathrm{K}^{t}$ Form. See ungulatus.

Hook. See hamus.

Jora'rius. Continuing but an houl.

Ilomizos'ral. Parallel to the ho. rizon. Leaves are horizontal, when they form right angles wilh erect stems.

Ilons. See spur.

HonN'-Fors. Shaped like a liorn, or rather like a eock's spur. See spur.

IIorolog'ium. A botanist, who watehes the progress of vegetables as they approach maturity, particularly the developement of flowers, throngh every hour of the day. A table kept of sueh progress iscalled, by the French, horologue.

IIu'midus. Moist, humid.

Ilu'MHuse, humifusus. Spread over the ground. Richaid defines it, spread on the ground and not rooting

Ilum'ilis. Low, humble.

Husk. The larger kind of glume ; as the husks of Indian corn.

Hy'alive, hyali'nus. Colourless. Transparent like glass or water; as quartz in granite.

HYBER'NICLE, hybernac'ulum. See bud.

IJybernalis. Growing in the winter season.

HY'BRID, hy'lirida. A mule. $\Lambda$ vegetable prodneed by the mix. ture of two different species. The seeds of liybrids will not propagate. 'They are prodneed by sprinkling the stigma with the pollen of a ditforent species. Care must be taken in such cases to prevent any pollen of its own species fiom falliug on it first.
Hydrop'Terints. Water fern. A new order of ferns. It is adopted by Pursh, lorrey, \&e. Isoetes, azolla and salvina are placed here.

Hyemu'lis Growing in the win. ter season.

Ifyme'nium. An exposed or naked, dilated, appropriate membrane of gymuocurp fungi, iu which the seeds are imbedded.

Hrperdec androus. Flowers colltaining more than ten stamens.

Hypocratcrifor'mis. See salverform.

Hypodecandrous. Flowers con taining fewer than ten stameus

Hypog'ynus. Under the style.

\section{J.}

JAG'GLD. See laciniate.

Jaws. See faux.

Icrituyology. The department of Zoology, which treats of fish. If includes those aquatic animals which bave gills and fins.

$I^{\prime}$ concs planta'rum. Figures $0 !^{\circ}$ drawings of plants.

ICOSAN'DRIA. (Eikosi, twellty ; aner, male.) See p. 13.

The ealyx is always nonophyllous, and the claws of the petals fixed into the inside of it along with the stamens.

Icosan'Drous. Belonging to, or varying into, the elass icosandrix.

Ic'lerus. The ehange of colour in leaves in autumn.

Imago. A perfect, full-formed in. sect. It is applied 10 express the state of an insect, after it bas passed from the erysalis to the insect state.

Imbcrlbis. Beardless See beard. Ia'Bricaze, imbrica'lus. Leaves, seales, \&c. lying over each other, or one covering the place where two others meet, like the shingles or tyles on a roof.

lmamginate. Having no bordu: or peculiar margiu. 
Im

In'pari-pinna'tus. Unequally pinnate. When a pinnate leaf is terminated by a simgle or odd leafct.

IMPER'FECT, imperfectus. Wanting the stamen or pistil. No lower is perfect without both organs; but with an anther and stigma the Hower is perfect, though destitute of caly $x$ and co. rol

I MUNC'TATE. See punctate.

Fncqua'lis. Unequal, wbich sce. Inaquivalva'tus. Valves of capsule or gluıne unequal.

Tua'nis. Having a spongy pitl.

lırper'tus. Hollow, but witluut any opening.

lnca'nus. See hoary.

Incarna'tus. Flesh-coloured.

INCI'SED, Inci'sus. Cut in like a gash with a knife, but not decp enough to be called a cleft. If the crenatures or serratures of a leaf are cut down, to appearance, with a slit or gash, this term applies.

Iscisor. Fore tooth. The flattish front cutting-tectl.

Iscu'NED, inclina'tus. Bent towarts each other. Also bent towarcts something different.

I vcLV'DING, inclu'dens. One thing containing another withiu it; as the calyx shutting uy, the secd, capsule or corol.

Inclu'sus. Enclosing. Opposcd to exsert.

IxcoMPLE'TE. See complete.

Inconspic'uus. Not apparent without the aid of a inagnifier.

IxCRAs'sate. Thickening When a flowcr-stem grows thicker upwarls towards the flower.

Is'CrEMEN' 'The quantity of ill. crease.

1 YCL ${ }^{\prime}$ BENT, incumbens. Leaning upon or against. When an anther lies, as it were, somewliat horizontally upon the top of the flament.

I. CEpred, incurvatus, Bent in. wards. As a leaf beut in at the point towards the stcin, a filaineut towards the pistil, a prickle towards the stem.

INDIG'ENOUS. Plants, growing naturally aud originally in a country. It is often very diflicult to dcterminc, whether a plant is exotic or indigenous. Whlo can say, whether the chess (lromus sccalinus) stone-seed (lithosperınum arveuse) and coekle (agrostemma githago) are native or exotic?

InDIsTinct. Applicd to insects, whose heads and trunks are in nne piece.

Indiri'sus. Undivided. Not cleft into parts. It may however be serrate, crenate or tonthed; it is therefore not the same as entire.

In'DURATrin, indures'cens. Becoming hard, tough, or leathery.

Indu'sium. A shirt. It is used by some authors for the thin membranous covering on the fruit of ferns. But Smitl prefers retaining the old name, involucre, which see.

Iner'mis. Sec unarmed.

Infor'ne. Downwards. Towards or near the base or root.

INFE'Rlor, inferus. Below. A calyx or corol is inferior when it comes out below the germ. Sec gcrm.

Inifimus. At the very bottom or base, lowest.

INFLA'TED, infla'tus. Appearing as if blown up with wind. A very small degree of inflation is soinetimes noticed in descrip. tions; as the calyx in silcne.

INFLEX'LD, infle $x^{\prime}$ Us. 'The same as incurved.-Smith.

INFLORES'CENCE, inflorescen'lia. The mode by whieb flowers are connected to the plant by the peduncle. It is of 10 kinds. 1. Whorl. 2. Raceme. 3. Paniele. 4. Thyrse. 5. Spike, 6. Unibel. 7. ('yme. 8. Corymb. 1 . 
Fascicle. 10. IIead. See each in its place.

Infrac'tus. Bent in with such an acute angle as to appear as if broken.

Infundibilifor'mis. See funnel. form.

Inodo'rus. Having no smell.

Inguinans. Staiued. Applied to fungi, \&ic. when the colour appears as if painted on artificially.

Inser'lus. Inserted, fixed to or on.

Insi'deus. Sitting upon.

Insigni'tus. Nlarked

Insirnc'tus. Furnished with.

In'teger. See entire.

Inleger'rimus. Very entirc, having no dentation whatever.

INTERFOLiA'CEOr's. Situated along the stem between the origin of the lcaves, nut opposite to them. Intermedius. - Between two extremcs.

JNTERNo'DE, interno'dius. The space between jornts or knots.

Inter'nus. Within the inside.

Interpositus. Placed between.

Intcrup'te. Interruptedly.

INTERRUP'TED, interrup'tus. spikc is intcrrupted, when leaves or smaller llow ers are interposed at intervals.

INTERRUPTEDLY FINAATE. When smaller leafets are interposed among the larger; as the potatoc and agrimony leaves.

INTERSCAFULARS The back fea. thers of a bird. between the bases of the wings

Inti'mus. Entirely within.

JNTOR'sios, intor'sio. Twisting, twining or bending from a strait upright position. See twining, contorted and twisted.

Intor'tus. 'Twisted inwards.

Intrafolia'ceovs. Within the leaf. A stipule in intrafoliaceous, when it origiıates a little above the origin of the petiole, which brings it, as it were, within the hosom of the leaf.
IntrodéCED. Not originally native. Brought from some other country.

Intror'sum. Inwardly.

INVER'SELY HEART'FORM. SeC Ob. cordate.

Invinda'tus. See sibmersus.

InVOLU'CRATE. See involucred.

INrold'CRE, involu'erum. That kind of calyx which comes out at a distance below the flower, and never encloscs it like the spathe. It is further distinguish . ed from the spathe in being of a leafy testure and colour, whereas the spathe is generally membranaceous or colliured. It is generally found at the origin of the peduncles of umbels; and sometimes attached to other aggregate flowers. When it is all on one side it is called dimidiate, halved. See partial.

involucres of ferns generally lie in the tops of the capsules, like a piece of linen spread out to dry; honce they are called indusizm, a shirt. They arc denominated cornieulatum, when cylindric, hollow and enclosing the seed.

INvolv'Cred, involucra'tus. Hav. ing involncres.

InVolu'cex. A partial involucre, or a little involucre.

Invol'rens. Arching over.

Is'volute, involn'tus Rolled in. wards A term in foliation; applied to leaves whosc opposite margins are rolied in and continued rolling, till the two rolls mect on the midrib and parallel to it. Applied to shells, it sig. nifies, that the spire is in whorls which are concealed within the shell, as cypraea.

Jolsts. Swelling knots, rings, or narrowed interstices, at rcgular intervals along culins, pods, spikes, leaves, Sic.

JUINT'ED. Having juints.

Irideots, Irides'cent. Reflect. 
ing light somewhat like a rainbow.

SRREG'ULAR, irregula'ris. Differing in figule, size, or proportion of parts, unoug themselves.

IRRITABIL'ITY. The power of being excited so as to produce contractile motion. That there is such a thing as vegetable urritability is evideut to every one, who exaiunes the common barberry llower. Touch the inside of a stamen near its base with the end of a horse-hair, or any thing about the same size, and it will instantly strike its anflier against thr: pistul and shoot a yuantity of pollen upon the stigma, or ill liat direction.

1su. See acutiusculus.

Isthmus. Long narrow joints in legumes or loments.

Jug'um. Yoke. In pairs.

Iu'lus. Sce ainent.

\section{K.}

Keel. The lower petal of a papilionaceous corol. The stamens and pistids lie enclosed in it.

- KFel'eg. Having a ridge resembling the keel of a boat or ship. A leaf, capeule, calyx, \&c. is keeled when it has the midrib, angle, or peculiar process, running alony the back of a compressed form, aud attached by one edge.

hER'NEI. See nucleus.

KID'NEY-FORM. Hollowed in at the base with rounded lobes and rounded end. Its breadth is gen. erally, as great as its length.

KNE'ED. See geniculate.

К potatoes.

KNoBs. (Cephalo'dia.) That kind of receptacle of lichens, which is convex, more or less globular, covered externally with a coloured seed-bearing crust, and placed generally at the extremities of stalks, originating from the froucl, permaneut ; rarely sessile. Sometime they are at first spanyles on filamentous lich. ens, and afterwards become convex irregular knobs. They are simple, compound or conglomerate.-Smith.

KNot. A swelling joint. See joints.

KNOT'TED. Having swelling joints.

KNOT'LESS. IVithout swelling joints. See enode.

L.

LA'BATE. Having lips; or a ca. lyx or corol diviced at top ints tivo general parts, sumewliat re. sembling the lips of a horse or other anional.

Labialc eorols are divided into ringent aud pessonate.

lingent, such as have the lips open or gaping.

Pcrsonalc, such as have the lips closed or mnffled.

Labyrinthifor'mis. Winding and turning by various iuvolutions and contortions like a labyrinth.

Lac'erated, lac'erus. 'Torn. Cut. or apparently torn, into irregular segments.

Lacin'ia. 'T he division of a calyx, corol, leaf, \&c. into which they are cleft, torn or divided

Lacin'ıate, laciniu'lus. Jagged. Irregularly divided and subdivided, cut or torn. Hardly differest from lacerated.

Lactes'crice, lactescen'tia. Milkiness. The milky juice of some plants; as the milkweed (ascle. pias.) It is also called by this, name, when the juice is red; as in the bloodroot (sanguinaria.)

Lac'leus. Milk-white

Lacu'nose, Lacuno'sus. Pitted. Hollow befwern the veins of a leaf. When the blisters are un. der side of the leaf instead of the upper. See bullate. 
Lacu'stris. Growing most naturally in or about lakes.

La'vis. Smooth, ever, polished ; not striate, or wrinkled.

Lancl'la. A thin plate. Applied to the gills or vertical plates un. der the hat or pileus of the agaric fungus, or toadstool.

- equa'lis. IVhen all the gills reach from the stem to the niargin of the bat.

inequa'lis or interrup'tus. When some reach but part of the way:

biseria'lis Whew a long and short gill alteruate.

triscria'lis. When 2 long and 2 slort gills alteruate in pairs.

- ramo'sa. When several gills unite in one, so as to appear branched.

$\longrightarrow$ decur'rens. When they run down the stem more or less.

- venosce. When so narrow as to have the appearance of veins.

LAMEL'LATE. In the form of thin plates, or having thin plates.

I.AM'isa. The broad upper part of the petal of a polypetalous corol. See petal

Lamnated. Consisting of several thin flat portions.

I A'NATE, lana'tus. Woolly. Coveled with curly, cronked, close, thick pubescence. Not so fine, nor so closely matted together as tomcrlose.

Zaver'olate, lanccola'tus. In the form of the lance of the ancients. When the length greatly exceeds the breadth; and it tapers gradually from neal the base to the apex.

Lance-o'vate, \&ic. lanceola'toova'tus, \&cc. Pertakir: of the lanceolate form and of that with which it is compounded.

I, anu'go. Down, or wool.

Lappula'ceus. Burr-like.
H,Anva. The caterpillar state of an insect. It is called maggot, skipper and grub, while in this state.
Laterifol'ius. Side-leaved.

LAT'ERAL, latera'lis. On one side

Latifol'ius. Broad-leaved.

Lateri'tius. Brick-coloured.

Lat'itans. Hidden, concealed.

$\mathrm{L} \Lambda \mathrm{T}^{\prime} \mathrm{TICE} \mathrm{D}$. Resembling networh:

LAx, Lax'us. Limber. See llac. cid.

L.EAF. That part of most vegetabies, which presents more surface to the atmosphere, than all otber parts ; and consists principally of the cellulat integument covered with the cuticle

Leaves imbibe and give out moisture; generally more with one surface than the other. Aquatic leaves perspire faster than dry-land leaves; which is the leason for their dryiug so inucl sonner. Some leaves imbibe sufficient moisture from the atmosphere for their support for a long time; as the commors liveforever will grow, if broken off and stuck up in a dry place.

Leaves are divided into sim. $p l c$, when one leaf grows ou one petiole; and compound when several leafets grow on one petiole.

They are $c v^{\prime} e r g r e e n$, remain. ing through the winter; or $d c$ cid'uous, falling off at the close of the year.

They are farther distingnished by their fornts, surfaces, and positions. All of which are described under their peculial names.

LE'AFING SEASON. That time in the year when most leaves come out. In North America, the proper leafing season is in April.

LE'AFET, or LE'AFLET. One of the lesser leaves which, with others, constitute a compound leaf. A simple leaf is never $a$ leafet, however small.

LE'afLEss. Destitute of leaves, naturally. This term does not 
apply in cases of defoliation, which see.

i. E'AF-stal.r. See petiole.

SE'ATY. Furmislied with lenves. Abounding in leaves. Leaves internixed with flowers on a spike.

LEAT'HERY. See coriaceous

CEG'Une, lcg $u^{\prime} m c n$. A pod, without a longitudinal partition, with its enclosed seeds attached to one suture only; as the pea. 'Those witl transverse partitious are usually ealled $l o m c n t s$, which see.

C.cGU'mors. Bearing legumes.

Lengtir and Breadiu. Wlien applied to bivalve sliells, length is measured from the beak or eartilage to the margin lielow, and brealth is taken in a transverse direction to the length.

Lrstic'ul a r, lenticula'ris. Lentilform. It is applied (1) a kind of glandular roughness on the surface of some plants. Form of a convex lens.

lepan'thium. Used as a substitute for some kinds of nectary by Nuttall, De Lamark, \&s:.

LEV'LL-TOP'PED. See fastigiate.

LI'ren. The innermost lay+r of the bark, or the last year's deposit. Smitl, page 25.

Libcra. Free, not adnate, or attached.

IIC'HENES. Sce p. 19 SE 26

Lid or mosses. See operculum.

Ligameint perforation. A per. foration through the shell of the anomia genus, by which it is attached to rocks, \&c.

I,IGHT. Various motions and incliuations of plants prove the effect of light upon them. Trees present their leaves oulward in quest. of light, because it is darkest in the centre Plants in a green-bouse all present the upper surfaces of their leaves towards the enlightened side of it. wheat-heads hang towards the sun. Mlost compound flowers follow the sun through the day. Plants deprived of the light lose their green liue; as potatoe tops growing in a dark eellar.

Ligno'se, ligno'sus. Woody.

Lig'num. See wood.

Lig'Ula. A strap or strap-form organ. It is generally applied to the membrane or stipule at the top of the sheath of a grass. leaf.

Lig'Ulate, ligula'tus. That kind of forel, in seme compound flowers, which consists of a single strap-lilie petal which becomes tubular at the base only; as all the forets in a dandelion, and the ray fluets in a sunflower.

Li'lia, LIL'IES. The fanily of lilies. See gentes.

Lilia'ceous. A'eorol with six pe. tals spreading gradually from the base, so as altogetlier tn exnibit a bell-form appearance.

Lrmb, lim'bus. 'The broad spread. ing part of the petal of a monopetalous corol. When applied to shells it means tlye whole cireumference or outlines of them.

Line, $l i^{\prime} n e a$. The breadih of the ereseent at the root of the fin. ger rail.

LIN'EAR, linea'ris. Continuing of the same breadtli througliout inost of the extent. Lineal leaves always, or with very few exeeptions, beeome narrowed or pointed at one or both ends.

LIN'EATE, linca'lus. Marked with lines.

Lin'guiform. Tongue-like. Thick, fleshy, linear, blint at the end.

Líon-tootil'vo. See runeinate.

Lip, or LIP'PED. See labiate. When applied to univalve shells, it means tlie outer expanded part of the opening.

Lircl'la. See eleft:.

Littora'lis. Growing on the seaeoast; also on the shores of rivcrs. 
Li'vidus. Dark grey, iuclining to violet.

I.OPE, lob'us. Divisions, which arc rounded, or parted by rounded or curved incisions. Sometimes it seems to be applied to cases where it has nothing to distinguish it from a segment cut off by a cleft incision, except by its being larger.

I. $0^{\prime} B E D$, loba'tus. Divided into lobes. Deeply parted, with the segments distant or spreading and large.

Loculcmen'tum. Sce cell. Cavities containing seeds

Joc'ulus. The little cell of an an. ther, which contains pollen.

I. MENT, lomen'tum. A legume pod with transverse partitions. This term is generally applied to the legumes in the natural order Lomentacæ.

Longifol'ius. Long-leaved. See relative proportions.

Longis'simus. Very long.

- Lon'gis. Rather long. See rclative proportions.

Loose. Open, not compact.

LOREs. The uaked lines or spots on a bird's head, between the eyes and the base of the bill.

Lo'vula. The long threads of Usuea. This lichen, so common on trees, is erroneously called inoss by most people.

Lu'cidus. Bright, shining. Nearly the same as nitidus.

I. V'NUlate, lunula'tus. Shaped like a crescent, which see.

I,vore. A lalf-moon-like depression just below the beak of a bivalec shell. It is anterior or postcrior according to the slope it is on. See slope.

$I_{U^{\prime} \Omega D}$, lu'vidus. of a palish, dull, deatlily colour. Most plants with lurid petals are more or less poisonous ; as tobacco, henbane, thorn-apple.

Justrk. The peculiar appearance of reflected light, as preented by a mineral.
Lutes'cent, lutes'cens. Approaching to a yellow colour.

Lu'tens. Yellow.

LuXv'Rrant, luxur'ians. See fultflowered.

LY'RATF, lyra'tus. Pinnatifid, with the divisions at the apex largest.

Lx'Rate-Pin'Nate Pinnate witl? the odd terminal Icafet largest.

\section{M.}

Macula'lus. Spotted.

MaILed. Covered witl a hard substance resembling armour.

MaLE. See staminate.

MANDIBLES. The upper jaws of a bird's bill. It is also applied to the horizontal pincers attached to the mouths of some insects

Manifes'tus. Very, apparent.

MA'Ny. Whenever there are more than are usually numbered of that kind; as we say, I-seeded, 2-seeded, 3-seeded, 4-seeded, many-seeded.

MARCES'CENT, marces'ccns, or mar'cidus. Sec withering.

$M_{A R^{\prime} G I N A T E D}$, margina'tus. IIaving a margin differing in some measure from the disk.

$\mathrm{MAR}^{\prime} \mathrm{GIN}$, mar'go. The circumference or edge. See border. The circumference of a shell.

Marit'imus. Growing uaturally near the sea-brard. It may be extended several miles from the water.

MAR'row. See pith.

Mas'culus. See staminate.

M M $S^{\prime}$ Ked. Personatc. Sec labiate.

Matrix. Gangue. The inineral immediately embracing an ore, within a vein in a rock.

MATd'RE, matu'rus. Full-grown, but not entcred upon a state of decay.

Meas'Ures. Proportion between parts is better than any measure. But when measures are adont. 
pl, they should be taken from parts of the hand and arm; because the parts of plants vary about as much as the hand; and in adopting these ineasures the same allowance slould be made.

1. Line, the crescent at the root of the nail. About onetwelfth of an inch. 2. Nail (un. suis.) Length of the nail. About lialf an incl.. 3. Inch (polles.) rength of the first joint of the thumb. 4. Palm Breadth of the four fingers. About three iuclies. 5. Shorl'-span (spithaIna.) Distance between ends of thumb and fore-finger. About seven inclies.

Long'-span (dodrans.) Distance between ends of thumb and little finger. About nine inclies.

l'oot (nes.) Distance between the point of the elbow and the second joint of the thumb. About twelve inches.

Cu'bil (cub'itus.) Distance het iveen the point of the elbow and of the middle finger. A bout 15 inclies.

Arm (brachium.) Distance hetween armpit and the end of iniddle finger. About 24 inch. es.

Fallom (orgya.) Distance between the ends of the middle fingers, when the arms are extended.

Medic'uxar, medicina'lis. P'lants possessing principles sufficiently active to entitle them to a place in the materia merlica. Many physicians daily trample under foot plants, whicb prossess similar qualities with those which they purchase from Europe, and often the very same plants; but being ignorant of those hotanical principles by which the names and properties of plants are ascertained, they are consequently ignorant of the absurdi. iy. See qualities.
Medio'cris. Averaging in dimen sions counpared with other parts. See relative proportions.

Med'ius. In the middle. This term is used when one part is betiveen the other parts, though sometimes much nearer one than the other; as a bract is in the middle rof the peduncle, when it is much nearer the llower than to the base of the peduncle. This name is sometimes given to species holding a middle place be. tween extremities, expressed by the names of other species of thic same geuns.

Mcdul'la. See pith.

Mislif'erous, mellif'era. P'oducing or containing loney.

Mclligo. Honey-dew on leaves.

Membrana'ceods. Made up, apparently, of the two plates of the cuticle, without any cellular integument between them. Nearly transparent, very thiı and colourless.

Membrana'tus. Flattened and re. sembling a membrane.

Mensu'ra. See measures.

Metrion, method'us. A mode of arranging plants in classes, orders, \&c. Richard has 14 pages on this head; in which he gives the methods of Tournefort and Linneus at length. But as we have given the method of Linneus under Grammar of Botany, and throughout the Dictionary ; and as Tournefort's method is no where adopted in this country; this article is prin. cirrally omitted.

It inay be observed that :

TOURNFFORT'S METHOD

Divides plants into herls and trces. Tle Hereaceous plants are divided into 17 classes. Fourteen of these are distinguished by the form of the corols; as, 1 . Infundibiliformis. 2. Personate, \&c. The other 3 classes are apc. talous and distinguished by hating stamens, but no apparent for 
ors, nor upparent seed. The TreE kinds are divided into 5 classes.

MID'RIB. The main or middle rib of a leaf running from the stem to the apex.

Milia'ris. In the form of millet seed.

Minia'lus. Scarlet, vermillion enlour.

Minutis'simus. Extremely small or milute.

Missice tongue. When the animal can thrust the tougue far cut of the mouth.

MI'TRE-FORx. Terminating in two divisions, in some measure resembling a bishop's mitre.

Mouares. Grinders. Teeth farthest back一double teeth.

Molendina'cer. Many winged.

Mol'lis. Soft

Mozruscous animals. Those that have the medulary masses, in which the sentient principle resiles, inveloped in a soft body ; as the oyster.

MONADEL'PHLA. (Monos, one; adc! phos, brother.) See p. 13.

Monadel'Phous. Belouging to, or varying iuto, the class monadelphia.

MONANiDRIA. (Monos, one ; (iner, male.) See 1). i2.

Mosil'iform. See granulate. Globular joints of autennae.

MIONOCOTYLE'DoNs. See cotyle. don.

MONOE'ClA. (Monss, one ; oikos, louse.) See p. 14.

Mona'crous, monoilcus. Belonging to, or varying into the class moncecia.

MONंOGYN'IA. (Monos, one ; gune, female.) See p. 16.

Monoper'alous. The whole corol in one piece. Sometimes it is so deeply partcd, that it appears to be polypetalous until it is pulled off and closely examined at the base. In niost moisopetalous corols, the stamens are atiached to the tube. They are divided into bell-form, funnel. form, salver-form, whcel-form, and labiate, whiclı see.

Monophyl'Lous. (Mon'os, one ; phullon, a leaf.) Oue-leafed. A calyx all in one piece. All the calyxes in the class icosandria are of this kind. They are often so deeply divided, that a student may mistake them for polyphyllous, without particular attertion.

Afonopteryg'ia. See wings. Onewinged.

Monopyre'nus. Enclosing but one nut or stonc.

Monosper'mus. One seed to a flower.

Monostac'hyos. (Monos, one; slachus, spike.) Single spiked.

IIon'strous. Plants producing any part different from the same part, when growing wild. As the rose has but five petals in a wild state; but, by rich cultiva. tion in gardens, the stamens are mostly changed to petals. Carnatious and peony are examples also. These are all monsters. See florist and full-flowered

Monta'nus. Growing most naturally un mountains.

MoON-Forar. See crescent-form. Mos'ses. See musci.

Moutr. See faux.

Mu'cidus. Resembling mouldiness, or mucor.

Mu'crosate, mucronaltus. Hav. ing a rounded end, tipped with a prickle; which often appears ratber an extension of the mid. rib.

Mule. See hybrid.

Multanguliz'ris. Many-angled. Having several corners or ridg es.

Multicapsula'ris. Many-capsuled. Several capsules to each flower. Multicau'lis. Producing many stems.

Multidenta'tus. Many-toothed 
Mi:L'TIFID, Multifidus, Manycleft.

Mulliflo'rus. Many-flowered.

sfrultil'obus. Many-lobed.

Aullilocula'ris. Many-celled.

HULtipar'Tite, Mulliparlitus. Many-parted.

Iul'tiplex. Many-fold. Having petals lying over each other in two rows.

Mul'tiplied, multiplica'tus. See full-flowered.

Multisiliquo'sus. Many pods proceeding from the same point.

Mectivalve, multival'ris.

A glume with many chaffs or valves. Applied to shells it embraces the order, which bas more than two shells to each animal.

Mullot'ics. Often times.

Mru'niens. Leaves drooping down and hanging over the stem, \&c. at niglit.

Muni'lus. See fenced.

Mu'Ricate, musica'lus. Armed with sharp spines. Covered with subulate prickles.

nIUS'CI, mosses. The second or. der of the class cryplogania. All mosses have lids'ou the capsules. See p. 18 \& 27.

Mul'icus. See awnless.

Mu'tilateo, mulila'lus. Not producing parts with their full com. plete forms.

\section{N.}

NA'KED. Wanting a covering analagous to that of most plants. As stem without leaves, leaves without pubescent, corol withput a calyx, seed without a pericarp, receptacle without chaff, pubescence, \&c.

Ma'nus. Dwarfish, very small.

NaP. See tomentose. Downy or like fur.

Napifor'mis. Resembling a turnip.

NA'rast, nat'ans. Floating. When the plant is fixed by the root at the buttom and its leares Boat on the top of the water, as the pond lily,(uymphæa.) Animals with the faculty of swimuing.

$\mathrm{Na}_{\mathbf{A}}^{\prime}$ TIONs. See gentes.

Na'Tive. Originally of that coun. try. Not introduced.

NAT'URAL CHAR'ACTER. The der scription of the parts of fructification at large ; witlinnt regard to any method: or at least so given as to be capable of being used under any method. See descriptions.

Nat'URAL cLass. See natural or, ders.

Nat'ural mingory. That de. partmeut of science, which treats of the productions of na. ture as they come from the hand of the Creator; without any de. composition or chemical chang. es.

It is generally divided into Wree hronches.

1. ZOOL'OGY. Which includics all animals; as Beasts, Birds, Reptiles, Fishes, Insects, Snails, Clams, Worms and Corals.

2. BOT'ANY. Which includes all plants As Palrns, (ìrasses, Lilies, Herbs, Trees, Ferns, Mosses, Liverworts, Seaweeds and Mushrooms.

3. Mineral'ogy. Which includes the unorganized mass of our globe. As Pit-coal, Com. mon Salt, Flint, Lime, Clay, Iron-ore, Silver-ore, Lead-ore, \&ec.

Nat'Urat or'Ders. An arrange. ment of plants according to theip natural afinities. Such an ar. rangement is of great use both in finding out a plant, and exam. ining its relations and qualities, See p. $22 \& 25$.

Linneus supposed that plants of the same natural order pos. sessed similar medical qualities. But the odour of plants must be taken into consideration; as all 
nauseous-scented umbelliferous plants are poisonous, while the sweet-scented are pleasant stomachics, \&c.

NA'velted. See umbilicatus.

Navic'ular, navicula'ris. See boat-form.

NAYAŃr. Floating. When animals float, without the effort of swimming, they are nayant.

NECESSA'RIA, polygamia. See p. 18.

Nrick. The upper part of the tabe of a corol.

Nectamiferous. Bearing nectaries. Producing honey.

Nec'tary, necta'rium. The part of a flower, which secrctes lioncy. It is cither a distiuct horn, gland, spurr, scale, cup, \&zc. or ihe claw or some other part of the corol secreting honey. This uamc is applied to any appendage to the flower, which has no otlier name.

Vemorosus. Growing naturally in groves, where the under brush is cleared away.

NeRro'SE, NER'VED, nervo'sus. Leavcs are nerved, when they have rib-like fibres running from the base towards the apex. In numbering nerres for a specific cliaracter, the midrib is counted witl the lateral nerves.

Yev'nsul. Having neither star.ens nor pistils, consequently barren; as the ray-florets of the sun-flower.

NICR'ED. See emarginate.

Níctitant arembrane. A semitransparent membrane, which covers the eyes of some aninals at pleasure.

dulaus. Nestirg. When seeds a."c placed in cotton, \&c. as in a ne t.

Nig'ci: Black.

Nig'ric ans. Blackish, sooty.

N'̈'gro- arul'cus. Dark-bluc.

Ni'sus formati'vus. That principle of vital energy, whicls tends to restcre lost or injured parts.
Nit'idus. Glossy, glittering.

Nin'cus. Snow-white.

Nod'Dise. See nutans.

Node, No'dus. Sec knot. Useil by Barton for internode. $\mathrm{F}$. Ph. p. 61 .

Nodole. A splieroidal mass of any mineral substance.

No'men, Nams. See generic name. and specific name.

Notcis'Ed. See crenate.

Nu'bilus. Grey and white, clouds. Resembiing cumulous clourls. See cumulus.

Nucamen'tum. See ament.

No'cIFors. Resembling a nut.

Nuc'leus. Nut or kernel, The in. ner seed or kernel is properly the nucleus; and its liard shelh is tlre putamen. But the whole including both putamen and nucleus, is the nut, nux.

Nu'dus. See naked.

Nudius'culus. Nakedish.

Nul'lus. None.

Numero'si. Many. An indefinite. number.

Num'crus. A determinate namber.

Not, nux. See nucleus.

Nu'tant, Nu'tans. Nodding. When above half of whatever if is applied to, droops or hangs down. See pendulus.

Nuta'tio. The various inclinations of the parts arising from the ef: fect of the sun's rays.

\section{O.}

Ob, obver'se. Reversed or invers: cd. Often combired with ovate, cordate, icc. as obcordate, inversely heart-form.

OBCON'IC. ('onic with the point, or apex, dowuwards.

OBCOR'DATE. Heart-form, with the apex next to the stem, or place of insertion.

OBLANCE'OBATE. Lanceolate with the base the narrowest.

OBL1'que, obli'quus. A position between horlzontal and verti- 
ral ; or between perpendicular and the plane of the base. It is aiso applied to leaves, petals, c:alyxes, \&c. which ure, as it were, cut obliquely; or whose linses are shorter on one side than on the other.

UBLosg, oblon'gus. Ilaving the length twice or more than that of the breadth, with the opposite sides somewhat paraltel.

(.)blongius'culus. Somewhat oblong.

OBo'val, obovalis. If it differs at all from ubovate, it must be more nearty oval-having the conds nearer equal in width.

Ogo'vate. Ovate, with the narrowest end toivards the stem or jlace of insertion.

Obscu're. Obscurely.

Un'SOLETE, OB'SOLETELY, obsole' I us, obsole'te. IVhen teeth, notches, serratures, \&cc. are obscure and appear as if worn out.

()blu'sc. Obtusely.

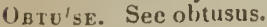

Oblu'sc-acumina'tus. Blunt with a small point.

Oblusins'culus. Obtusish.

Oblu'sus, ortu'se. Ending bluntly, or in an apex more or less rounded.

Oberer'sus, obver'se. See ob.

Os'rolvte, obvolu'tus. A term in foliation; applied to leaves where tino opposite ones are conduplicate, with one edge of rach leaf between the edges of the other.

Occipital. Pertaining to the back part of the read.

Dcrimatr. Eye-like spots, as on the wings of sume butterfies.

Occlu'sus. Clused.

Oc'hrea. A cylindric sheath or stipule. It is applied to the mernhranaceous stipules of most of the species of Polygonum; al. so of some species of Cyperus.

OCTAN'DRIA. (Octo, eight; ancr, male.) See p. 13.

QCTAN'Drous. Belonging to, or varying into, the class oclati dria.

Octo'fidus. Eight-cleft.

$O C T O G Y N^{*} I .1 . \quad$ (Oclo, eight; gunc, female.) See p. 10.

Oclolocula'ris. 8-celted.

Octopel'alus. 8-petalled.

Oclophyl'lus. 8-leaved.

Odora'tus. Scented, odorous.

Officina'lis. Such plants as are sold in the shops for some use, either in medicine or the arts.

Ojd, $\mathrm{Oi}^{\prime} d$ es. When this terminates a word it imports resemblance to the part or plant in whose name it is annexed. P'etaluid, resembling a petal ; thalictroi. des, resembling a Thalictrum, \&uc.

Oligospcr'mus. Few-seeded.

Onc-sitded. Flowers, \&e. on one side of a stem, \&c.

OPA'Que, opa'cus. Neither trans. parent nor slining.

Oper'culate, opercula'tus. Hav. ing a lid.

Opericulum. The lid or covering on the capsules of mosses. This is generally covered by the ca. lypire when young. After the calyptre is gone and the seeds are ripe, the lid falls also. This term is also applied to the cover. ing of other capsules, resembling the lids of mosses. When applied to Conchology, it means a cartilaginous, crusty, or shelly apriendage to the anional by which it closes its shell after its body is drawn into a univalve shell.

Op'posite, opposi'tus. Standing at the same height with base against base, on different sides of a stem.

Opposite. Oppositely.

Oppositifol'ius. Set opposite to the base of a leaf; as some pedun. cles and stipnles are placed.

Oppos'ile-pinnallus, Leafets of a pinnate leaf setopposite to each other.

Qrbicula'ris. Nearly circular. 
Orbillke. See orlss. Little orbs. Uriss. That kind of receptacle of liehens, whieh is flat, orbieular and dilated, of the substanee of the frond, terminal, peltate, without a border, but often surrounded with radiating shoots. The membranc, or disk, under which the seeds arc lodged, is smooth, nearly of the colour of the frond. Spurious orbs bordered like shields or spangles when young, are sometimes found in the gcnus cornicularia.-Smith.

OrCHIn'EOUs Co'roz. Like the orchis; having 4 arched petals, and the fifth longer.

On'GYA. Fathom. See measures. OR'IFICE. Any hole or opening into a eapsule, eorol, \&e.

OrNitnocogy. That department of zoology, whieh treats of birds.

Os. See faux. Mouth, jaws.

Os'seous. Bony, hard.

$O^{\prime}$ ral, ova'lis. The length exeeeding the breadth in any propor. tion, with the two ends of an equal breadtl, curvature and form, or nearly so; the sides curving from end to end.

Ota'rium. Used by Nuttall for an ovate germ.

O'rate. Egg-form. The length exeeeding the brendth in any proportion, the end next to the stem, exeeeding the other in breadth; the sides eurving from cnd to end.

OYjPAROUS. Animals produced from eggs, as birds, fish, \&e

Ovoldal. Somewhat egg-shaped. Orus. An egg.

\section{P.}

Pa'gina. The surface of a leaf. The ipper surface is pagina superior; the lower surface, $p a$ gina inferior.

$\mathrm{P}_{\mathrm{AL}}^{\prime}$ ATE. A prominence, process or clevation in the lower lip of a labiate corol, which tends more or less to elose the throat. pal'ea. Sce chaff.
Paten'cegos: Sce chaffy:

Palma'ris. Hand's breadils.

PaL'Mate, palma'tus. Divideil deeply and spreading, so as to resemblc the hand with spread fingers. When the divisions nre very narrow and almost down to the stem of a leaf, it is ealled pcdate, from its supposed resemblance to a bird's foot. Some pedate leaves are hardly connected at all at the base, and almost run into tlac compound digitatc leaf.

Palpi Feelers. Proccsses or fibres attached to the mouths of inseets.

Palu'stris. Growing naturally in swamps and marshes.

Pandurifor'nis. Guitar-form, or fiddle-form. Oblong, broadish near the base and contracted on the sides.

PaN'icle, paniciula. When the peduncles along the sides of the main peduncle of a racemc, are divided, it takes the name of par niele ; as oats. But if it is still in a elase, compact form, it is called a thyrse, as the lilac.

PaN'ICled, panicula'tus. Disposed in the form of a panicle ; or bearing panicles.

Pariliona'ceous. (Papilio, a hut terfly.) Butterfy-form; as the pea-flower when eomplete, it eonsists of the banner, the upper petal which generally spreads over or above the others; the wings, the two side petals, next below the bunner; the keel, the lower boat-form petal, generally enclosing the stamens and pistil. It is sometimes ealled the pea-bloom flower.

Papilla. Flesly process or point.

PaPILlo'se, papillo'sus. (Papilla, a nipple.) Covered with fleshy points or protuberances. Sec verrueose.

Parpo'se, pappo'sus. Bearing pap? nus o: aigrette. 
Pappus. See aigrette. Seed down.

Paruzo'sf, papulo'sus. (Papula, a pimple.) J'imply, bladdery or blistered.

I'ARABOL'sc. Conic, with the top rounded off, considerably below where it would terminate in the apex, if completed in the conic form.

Pan'ALLex, parallel'lus. Tivo lines or opposite sides, rumning nearly equal distances from each other. The opposite edges of a leaf are parallel when the leaf is linear.

Parasit'lc. Drawing support from another plant, Growing out of another; as the dodder.

Puren'chyma. A succulent vegetable substance; as the thick part of leaves between the opposite cuticles, the substance around the pith of herbs, the pully part of apples, \&c.

PaRI'ETal. parielalis. Walled around. Having an enclosing or encircling ring.

PAP'TED, parti'tus. Deeply divided, almost $t$ the base.

far les prima'rix. The three primnry parts of a vegetable are : 1. The rool, or descending part. 2. The herbage, or ascending part, except ; 3 . The fructificalion, comprising the flower and fruit.

"'sn'tial, partiallis. Particular, not general. Applying to an entire part of a general whole. 'I'ise perianth, involucre, petiole, \&ic. of one floret, or of a separate part of all the florets, which with others constitute a comyound or aggregate. The perianth, involucre, \&zc. to the whole is called general or universal.

b'ar'traLe, partíbilis. Easily separating into parts. Bipartible, into 2 parts. Tripartible, into 3 parts, dic.

Parrir'los. The membrabe, \&c. which divides pericarps into cells. It is parallcl, when it unites with the valves, where they unite with each other. It l. conirary or transverse, when it meets a valve in the middle, or in ally part not at its suture, or juncture with another.

Patel'luta. See spangles.

Pa'ters. Spreading so as to form a moderately acute angle; considerably less than a right one, or a square.

Palcntistsimus. Spreading almost to a right angle

Pat'ulus. Somewhat spreading. Open, loose

Pau'ci. Few in rumber.

Pauciflo'rus and paucifol'ius. Fewflowered and few-leaved.

I'r'A-BLOOM. See papilionaceons. Pećtinate, rec'tinated, peclina'tus. So fiucly pinuate or pinnatifid as to resemble the teeth of a comb.

PECTORAL Fins. A pairgrowing on encl side of the thorax, or breast.

Pedallis. About a foot high.

PE'Date, perla'lus. See palmate. Bird-font like.

PEDAT'IFID, pedalifiidus. Nearly the same as pedate; perhaps liardly so deep-cut.

PED'icer, pelicellus. $\Lambda$ partial peduncle.

Pen'icellen, Penicer'llate, pr. dicella'tus. Having a pedicel.

Pénuncle. See pedunculas.Flower stem.

PE'DUncled, peduncula'tus. Hav. ing a peduricle.

Peluncula'ris. Ippertaining to, or fixed on, a peduncle.

Pedun'culus, PF'DUNCLE. The stem bearing the flower and fruit, which does not spring nakert from the root. Those which spring immediately from the root. without leaves, are called scape. As the dandelion has a scapc, the

apple a peduncle.
PELL'SCLE, pelliç'ula. A thin mema 
hrane-like substance. The close covering of some seeds; sometimes it is a little inucilaginous or downy.

Pellucid. Transparent, translucent, or limpid.

Pel'tce. See targets.

Pei.'tate, pelta'lus. Having the petiole attacued to the under side of the teai. In all cases of leaves and fiat stigmas, when tise petiole or style is attached to the disk insterd of the matgiu, they are peltate; as the teat ot uasturtion and the stigna ot the yetlow water-lily.

Pen'dant. Hahgilig vollil.

Paxidulous. Iruen the whole or the part droogs, or thangs dums.

Pen'ciL-Forni, pennucil'iyur'mas. sbaped like a panter's pencil, or little round fanal-urusli.

Pcrtacoc'cus. A 5-gramed capsule.

Pentago'nal, pentugo nus. Fivecornered.

PENTAGYN'LA. (Pente, five ; gune, female.) see p. 10.

PENIAN'DRla. (Fonte, five ; aner, inale.) see p. 17.

Pentan'urous. Belonging to, or varyiug into, tue class pentandria.

Pentapetaliss. 5-petalled.

Pentaple,yg'ia. See ivings. Fivewniged.

Pentaphyl'lus. 5-leaved.

Percining. A bird having grasping teet.

Percgri'nus. Foreign, strange, wanderiug.

Peren'Niat, peren'nis. Contiuu ing more tlian two years.

Perexillis sleuder.

PER'FECT FLOW'ER. Having bulis stamens and pistils.

Perfuliate, perfolia'tus. Per. forating a leaf Havin - the stem running through the leal. Bu the leaf is not formed by the union of opposite bases, as it the boneset (eupatorium ;) for in this case the leaves are connate.
It is applied to antennae when the main thread passes through the joints.

Perfoliate is sometimes the specific name where the leaves are nearly connate (as eupalorium perfoliatum;) and even where the leaves are merély clasping (as campanula perfo. liata.)

i'en'furate, Períforated, perjora'tus. Having holes as it pricked through. Punctate may differ in preseuting spots like points, which are not holes. rerluse perbaps is syon nynous witi perlouated. These dots may be seen by holding st. John's wort aud many other leaves to the light This term is applied to stigmas, drupes, dec.

Pекантн, peran'thium. (Peri, absu, ; anthos, flower.) That kud ot criys, nhich is immediately adjonting the corol, stamens and protil, or to sucli of these urgans as are present. It is superior when it grows on the gern ; it is inferior, when it grows out froa beluw the germ. See monophyllous und polyphytlous.

Pen'ICARP, pericarpium. (Feri, abuit ; karpos, truit.) seedcase. Aluy bag, shell, pod, pulp, berry, or other substance, enclosug the seed.

Pek'icheth, perichce'tium. (Peri, ar,uut; chaile, crest.) An invofucte surrousding the base of the peduncle of mosses, annong the leatets, but differing from tireu in torm. See caly ptre.

icrid'ium. A round membraneous dry case, enclosing the seeds in some augiocarp fungusses.

PER'IGONE. A perianth calys, ol corel.

A EK'ISPERM. A substitute for pericari' ${ }^{\prime}$ - Nuttall.

IERISPOR'ius. Capsule. Nuttal] uses it to express a chaffy covering to seed. 
t'eristom'ium. The fringe, tceth, or membrane, around the inonth of the capsules of mosses, under the lid.

perithecium. A perianth-like organ surrounding the seed-cases of lichens, or capsules of mosses and fungi.

PER'AIANET. Any part of a plant is perunauent, which remains longer compared with other parts of the same plant, than is usual for similar parts in most plants. As the calyx of the quince remains on the end of the fruit, till it ripens.

Perpusil'lum. Very little.

Pcrsis'lens. See permanent and ring.

Per'sonate, persona'lus. See labiate. Mufled, lipped flower.

'entu'se, pertu'sus. Punched. See perforated

Pes. See measures. One foot.

PE'Tal, pet'alum. The coloured leaf or leaves of the corol. The petal of a monopetalous corol is divided into the tube and limb; which see. Each petal of a polypetalous corol is divided into the claw and lamina; which see.

Pr'tal.Form, pelalifor'mis. Re. sembling a petal in shape.

Pctal'inus. Attached to, or being part of, a petal.

PE'Taxord, pelaloi'des. " Maving petals, resembling petals.

PE'Tiore, peli'olus. The footstalk of a leaf. Leaves which have no footstems are sessile.

PETIOLA'TE, PE'TIOLED, petiola'. tus. Having a petiole.

Petiol'ulus. A partial netiole, which connects the leafet to the maiu petiole; as the butternut.

IIsENOG'asiovs, (of phaino ti) shew.) Having the stamens and pistils sufficiently apparent for classification. Applied to all plants, not included in the class cryptogamia.

Phani'ceus. Purple, dark•red.

Prstol'ogy. (Plute, a plant; logos, a treatise or discourse.) The science which treats of the principles of vegetables. It is nearly synonymous with the physiology of vegrtables.

Pic'tus. Blueish-black, resembling rlark pitcl.

Pileus. The hat of a fungus. The top and most spreading part. It may be witlout stype, and thus constitute the whole ascending part It always contains the speds, though it requires the highest magnifiers to discover them in mostcnses. See Lamella. Pilid'ia. See puft's.

Pinfáerous. Bearing hairs.

Pircar. Columella. "The column of $n$ univalve shell.

Pulo'se', pilo'sus. Hairy. Iraving distinct straitisl hairs. Pappus is pilose, $O r^{\circ}$ it is simple, wheo each hair is without any lateral branches. Sec aigrette.

Pil'us. A hair. An excretory ducl of a bristly form, leading off a fluid. See sting.

Primited See papulose.

Pin'na. A wing-feather. If is applied to leafets, which resemble feathers by their positions.

Pin'Nate, pinna'tus. Winged, or feathered. Leaves are pinnate, when distinct leafets are arrangedalong opposite sides of a simple petiole. See bipinnate and tripinnate.

Pinnat'ifrd, pinnatif'idus. Cntwinged. Leaves are pinnatifid, wher, instead of leafets as in pinnate leaves, segments or divisions of a leaf are along opposite sides of the midrib. Pinnate are compound, but pinnatifid are simple ; because the divis. ions never reach the midrib. When pinnatifid leafets are on a pinnate leaf, it is called pinnate-pinnalifid.

Pis'trllate Flow'Er. Having pistils only, without stamens; as the flower of the fertile cucumber. 
Pis'ril, pislitlum. The central organ of most flowers. It generally cunsists of the germen, style and stigma. But the style is frequcrtly wanting; then the stigma is seated on the germ, or sessile. The stimm receives pollen from the anther, and, in some manuer not yet discovered, fertilizes the germ. IV ithout this operation, no preffect seeds are produced See flower, style and stigma.

Pistillif'erous. See pistillate.

Pitcia'er-form. Ser urceolate.

$P_{\text {Itn. }}$. The spongy substance in the centre of the stems and roots of most plants. Most wuody stcms have 110 appearance of a pith after they bcrome old

Puts, (syphellie.) That kind of receptacte of lichers, which con. sists of open, cup-likc, naked, white or yellow littlc spots, on the under side of the frond ; which is generally downy. They are at first immersed, globose, minute dots, which at length burst with irregular margins, and discharge a powder.

Pir'ted See lacunose.

Placcn'ta Fleshy receptacle.

Pracenta'tron. The disposition of the cotyledons in the germination of the seeds.

PLA'1TED. Folded somewhat like a fan, when nearly full spread. In foliation it is morc closely folded.

Plane. Flat, with an even surface.

Pla'no-con'vex. Convex or roundish on one side and flat the other.

Plant. Any substance growing from seed. As tree, grass, puffball, mould. Ser vegetable.

Ple'nus-flos. See full-llowerrd.

Plicaltus. See plaited folded like a fan.

PLimo'se. Feather-like.

Punao'se, pap'pus Featbcr-tuke down. When a tair bas otber hairs arranged on opposite sides of it Applied to a mineral having fibres divergung from a line or kund of midrib.

Plu'mula. The ascending part of a plant at its first germination.

Plu'rimus. Very many.

Yov. That kind of pericarn which is composed of tuo valves with the seeds attaclied tri one or hoth sutures, or a longitudinal partltion at the cdges inmediately adioining the sutures. The pod is either a legume or silique.

Pede'tia. The peduncles of lich. ens, whether hrllow or solid.

Poin'tal. See pistil. Central or. gans of a flower.

Poisers. Gilubules oll slender stems under the wings of some dipterous insects.

Po1'soxs. The definition of poisons and tlee manner of their operatiou las tot yet bcen satisfactorily explaired. It will bere be no farther noticed, than as it respects vergetables. See natural orders, and $r .50$.

Poi'sonotis veg'etables. Persons of all descriptions have frcquent occasion to make some use of plants, when they are not in a situr'ion minutely to investigate their nature and qualities. As many plants are narcotic and injurious to the human constitution, it is very convenient ta have at hand, or in the inemory, a few concise rules on this subject. Such have been selected with great care, and set down at $p 50$.

Pollen. See p. $5 . \quad$ On being vitwed through a magnifier, they are found of various forms. In the sunflower, it is a prickly ball ; in geraninm, perforated; in comfrey, double; in mallows, a torshed wheel; in violet, angular ; in daftodil, kidney form, sec.

Pollin'ia. Rolls or masses of pollen, not included in cells of an. 
Ther's of the commou form and texture ; as of the orchis, asclepias, \&ac.-Nuttall.

Pollinif'erovs. Bearing pollen. POLYADEL'PhiA. (Polks, many ; adelphos, brother:) See Rejected classes.

Polyanez'phous. Belonging to, or varying into, the class polyadelpbia.

POLYAN'DRIA. (Polus, many; aner, male.) See p. 13.

Polyan'Drous. Belonging to, or varying into, the class polyandrice.

Polycotrien'onous. Plants with more than two cotyledons. See cotyledon.

POLYGA'MIA. (Polus, many ; gamos, murriage.) Many unions. The name of the twenty-third class as established by Linneus. It comprises all plants, which have some perfect finwers, and others which are staminate and pistillate, or both kinds. This class is divided into three orders. 1. Monocia, having perfect flowers and either staninate or pistillate ones or both on the same plants. 2. Dicecia, having perfect llower's on some plants, and either staminate or pistillate flowers oul others, of the same species. 3. Tricecia, having perfect flowers on some plants, staminate on others, and pistillate on others of the same species. This class, like the 18 th, is abolished by Persoon and others, and the plants under it distributed among the other classes. President Smith thinks it ought to be discarded.

Polyg'amous. Varying into, or inclining to, the class polygamia.

Polygo'nus. Many cornered, or many-angled.

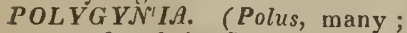
gune, female.) See p. 16.

Polymor'phovs. Presenting various forms and appearances.

PolyPeT'alous. Many-petalled.
If the corol consists of more than one petal, it is polypetalous.

Polypiyz'lovs. Many-leaved. A calyx of more than one distinct piece is polyphyllous.

Polypre'nus. Kunclosing more than one nut, or stone.

Polysper'me. Many-seeded.

Polystucin'ius. Many-spiked.

Powe, po'mum. A pulpy pericarp vithout valves, which eontains within it a capsule. See berry, and note the difference. Apples, quinces, \&c. are pomes.

Pomif'crus. Bearing poines, or -apple-like fruit.

Po'rous, poro'sus. Full of holes, cellules, or tubular openings.

Porrec'lus. Lengthewed out, stretclied, straitened.

Posterior slore. See slope.

Pree cox. Rare-ripe. Coming to maturity early in the season. Flowering before leafing.

Premon'se, Pramor'sus. Bitten off. Terminating bluntly, as if bitten off. As the root of the pedate or birdfoot violet.

Pras'imus. Green, like a leek.

Praten'sis. Growing naturally in meadow land.

Prenensile. The tail of an animal, or uther limb, formed for coiling around other bodies for the purpose of holding on by them.

Prem'ens. Pressing.

PriCK'LE. A sharp process fixell to the bark only, not to the wood; as on the raspberry, rose, barberry.

Prismat'ic, prismal'icus. Linear, with several flattish sides. A cylinder with flat sides.

Probos'cidcs. Proboscis-like. Resembling a projecting horn.

Proboscis. An elongated nose or snout. It is a tubular process, whether a tubular continuation of the snout, as of the elephant, or a tubular sucker, as of the musquetoe, it is always adapted 
to the structure of the animal in furnishing itself with food.

Proce'rus. 'Tall, elevated.

Proc'sss. A projectung part.

Procun'Bent, procumibens. Lyiug on the ground.

Profun'de. Deeply.

P'noliw'krous, pro'lifer. Putting fortl branches or flowers from the centre of the top of a preceding one.

Prom'1NENT, pro'minens. Standing out more or less beyond what is usual in other plants.

Promin'ulus. A little prominent. P'o'nus-dis'cus. The under side, or back of a leaf, upwards.

Prop. See fulcrum. Tendrils and other climbers.

Proparition. Seeflower. Extendiug plants by seeds, roots, \&ac

Propalgo. See gemratio.

Propa'gula. See efllorescence.

Propen'dens. Apparently on the point of falling.

Prop'er, prop'crus. See partial. Part of a whole.

Pros'trate, prostra'tus. See procumbent and humifuse. Lying oil the ground.

Protru'ded. See exsert. Projecting ont.

Protrisilf. Capable of being protruded. It is applied to the lieads of animals, which may loe thrust out or forward, as that of the tortoist.

Prox'imus. Very near.

Pruina. The mealiness or hoariness on plums, peaches, \&c.

Pruinose. Covered with a frostlike neal.

Pru'riens. Hairs which excite itching.

I'scu'do. When prefixed to a word, it implies obsolete or talse.

Pseudo-gorphous. False faced. It is applied to crystals whicl are formed in, or upon, other crystals and take their form. As pseudo-morphous quartz erystals, are such as are forined in the inner castings of disintegrated cubic crystals of iron pyrites, or on the outside of calc spar, fluor spar, \&c.

PuBes'cent, pubes'cens. Hairy, having laairs, wool, down, glandular hairs, \&c.

Puffs, (pilidia.) That kind of receptacle of lichens, which consists of little round bordered knobs, whose disk finally turns to powder. It is at first covered with a membrane aud often clothed with a fine grey hoariness. These receptacles are elorigated below into a stalk fixed to the clust, but totally different from it.

Pui'lus. Dull brownish colour. PuLP'x, pulpo'sus. Filled with a tenacious kind of parenchyma. Thick and succulent or spongy.

Pulver'ulent, pulverulen'tus. Turning to dust.

Polvinatus, Cushion-like. Applied to the pileus of a fungus, which is thick and corky or spongy.

Pulvi'nuli, (garden beds.) Cushions. Excresences found on the surface of the fronds of some lichens, sometimes clustered o: branched. Theil use is unknown.

P'u'milus. 5mall, low.

Punculed. See perforated.

Punc'rats. Dotted or sprinliled with coloured, generally diapha. nous, specks. See perforated.

Puncticlulate. Having minnte puuctures.

PUN'GENT, pun'gens. Sharp, piercing, pricking.

Punicicus, Scarlet-coloured.

PupA. Chrysalis, nympl, amelia. The quiescent state of an insect after passing from the larva state and before it becomes a perfect insect.

Purpuras'ccns. Inclining to a pulple colour.

Purpur'eus. Purple.

Pusil'lus. Low, small, diminutive. 
Puta'mas. Nut-shell. See nucleus. Pyramidallis. Conic, pyramidform.

Pyrifor'mis. Tear-shaped

Pyritiferous. Bearing iron py. rites. Containing sulphuret of iron.

\section{Q.}

RUADRAN'GULAR, quadrangula'ris. Having four corners, or angles.

QUAdRicap'sular. Having four capsules.

Quadridentallus. Four-toothed. Quadrifa'rius. Facing 4 ways.

QUAD'PIFID, quadrifidus. Fourcleft.

Quadrifio'rus. Four-flowered. Quadrij'ugus. Four-paired. Quadril'obus. Four-lobed. Quadrilocula'ris. Four-celled. Quadriner'vis. Four-nerved. Quadriparti'tus. Four-parted. Quadrival'vis. Four-valved. Ruadrivascula'ris Four cup-form cells.

Quar.ities of rlants, Richard says that plants of the same taste and odour, are generally possessed of similar qualities. Also that the smell and taste are always the same. He divides the odours of plants into, 1. Fragrant. 2. Aromatic. 3. Ambrosiac (resembling amber.) 4. Al. liaccous (resembling garlic.) 5 . Fetid (as asafoetida, \&c.) 6 Nauseous (causing the stomach to heave.) As the fragrant, the aromatic and ambrosiac, are always free from all hurtful qualities, and as the fetid and nauseous are generally poisonous; it seems that mankind lave in some measure an instillctive principle by which their food is to be selected.

Quater'nus. Four together in a whorl.

Qui'nus. Five together in a whorl.
Qu'sate, quinalus. Five leafets on one petiole.

Quinquangulu'ris. Five-cornered. Whien a leaf has five points; as the cucumber.

Quinquecapsula'ris. Having five capisules

Quinquecos'/alc. Five-nerved. Quinquef'idus. Five-cleft.

Quinqu'flo'rus. Five-flowered. Quinquej'ugus. Five-praired. Quinquel'obis. Five-lobed.

Quinquelocula'ris. Five-celled. Quinquener'vis. Five-nerved. Quinqueparti'hus. Five-parted. Quinqueval'vis Five-valved. Quinquerascula'ris. Five cup. form cells.

\section{R.}

Race'me, race'mus. (Rux, a bunch of grapes.) That kind of inflorescence, wherein the florets have undivided pedicels arranged along the sides of a general peduncle. As currants.

RACE'MED, racemo'sus. Flowers ils racemes

Pac'rns, (Rachis, the hack-borie.) The fliform receptacle connecting the florets in a spike. As in wheat heads. It is sometimes put for the midrib in ferns.

Ra'diay. Belonging in the ray.

Ra'date, radia'tus. The spreading florets around the margin of a compound flower. It is also applied to a division of animals; as the animals inhabiting coral rocks and sponges.

Radiated animals. Those whose sentient principle resides in a medulary globule, spheroid, or ring, with radiating branclies; as the polypus which iuhabits coral rocks, the tape-worm, \&c.

RAD'1CaL, ralicalis. Proceeding from the root without the intervention of a stalk. As the lcaves of plantain. 


\section{R E J}

Rádicans. See rooting. Roots proceeding from stems, leaves, \&ic

Radira'tus. Sending off roots.

RAD'ACLE, radiclula. The little fibrus branches proceeding from thr an in root; which imbibe the moistul's and other nourishunent for the plant

Rad'ius. Ser ray. Edying florets. Ru'dix. See root.

RAG'GED. Soe squarrose.

Ramen'tum. Applied to the loose scalcs frequently in the augles of petiolcs, \&cc. called in Eirglish, raments.

Ra'meum fol'ium. See branch leaves.

Rainiferus. Producing branches Ramossis'simus. Very braisch $:$ ng. Rumo'sus, Ramo'se. Branching. Ra'mulus See branchlet. Little branch.

Ra'mus. See branch.

Rariflo'rus. Flowers few and distailt.

Rarifol'ius. Leaves few and distant.

Ray. The onter malgin or cir. cumference of a compound fiower. It is also applied to the pe dunctes and out... finrets of au umbel; particularly when they differ in any reapect from th.. inuer, or d sk, ti rrets. Also to the bony spiries of th" fins and gill meinbmines of fish.

RA'yed. Having l'ays

BeCeP'racle, rectpia'culum. The basc by which the other parts of the fructification are connected and supported; bring the end, or at the end, it the peduncle. It is considerahly used in the generic charac.ers of rompoun. flowers ; but very little noticen: in any others. Perbaps this par: may hereafter be nnticed on ac. count of the change, it in some way produces on the vegetable secretions Dr. Smirin mentions (he wholesomeiress of some fruits, while the other parts of the plant are poisonous. See page 392. Every nre has notieed the delicate flavour of the poud-lily, (Nymphea odorata,) while all brck of the receptacle is extrcmely difierent. $v_{u m}$ rous similar instances may be cited to prove the very great change in some way effccted by the receptacle. IVhen Persoon applies receptacle (receptaculum) to a capsule, he intends the columella.

RECLI'NED, reclin't'tus. Bent down so that the apes of a lcaf, \&c. is lower than the base. Applicd to the stem it implies that it is bowed towards the earth.

Recorepostitus. Twice compound. Recon'ilitus. Concealed.

Rectius'culus. Straıtısh.

Rec'tus. Strait

Recurived, rerurratus. Curved dow II ards.

Recuti'tus. Appear's as if peeled.

REFLEX'ED, reflex'us. Bent back, nearly or quile fo touch the stern or pedincle.

REFRAC'TED, refractus. Bent back in an anyular torm, so as to appear as if broken

Reg'num veget'abile 'The vegetable kingdom as taken into view with the animal and mineral.

Reg'ular, regula'ris. See equal. Rejected Classes Linueus distributed all plant into 24 artifcial classes but his eleventh, eighteenth and twenty-third classes, are cousidered by many botanists, as very illconstant in their character. In the annexed Grammar of Botany, they are omitted, and the plants of each are distributed among the other classes.

The rejected classes being re. tained by Muhlenbcrg, Bigelow, and some other distinguished botanists, they are defined here

Dodecandria, the 11 th class of Linneus. 
It includes those plants whose lowers are perfect, and contain from tivelve to nineteen stamens to eaclı; as the wild ginser, purslane, agrimony, and louseleek

Polyadelphia, the 18th class of Linneus.

It includes those plants whose lowers are perfect, and contain stamens united by their filaments in more than three parcels; as the St. John's wort.

\section{Finneus.}

Polygamia, the $23 \mathrm{~d}$ class of

It includes those plants whose flowers are perfect and staminate or pistillate on the same plant, or on different individuals of the same species; as the ginseng, itch-weed, maple tree, ash tree, and peperidge tree.

Rifuected Orders. Some of tho artificial orders of Linneus are omitted in the annexed Gramunar of Botany, and their plants distributed among other classes and orders. They are the following :

Monogamin, the 6 th order of Iinueus in the class Syngenesia.

It includes those plants whose Howers are perfect and not com. pound, and contain stamens with united anthers; as the lobelia and touch-me-not.

Monoecia, Dioecia, and Trioecia, are the three oriers of the rejected class Polygamia. The order monoecia includes those plants, which comprise all that is necessary for the character of the class in one plant-dioecia, in two plants-trioecia, in three plants.

'The orders between dccag'ynia and polygynia, also beyond mo. nadelphia, are unnecessary. 'Their' definitions are implied under their associate orders.

REL'Ative PRoto'Rtions. When dimensions are expressed inde. finitely, as long, very long, short, large, \&c. sucl expressions art: to be understood as long, \&c. compared with the proportion which similar parts usually bear to other paris, in plants general1y. But when such terms are used for specific names, the proportion between the parts of species of the same genus, which were known when the nanes were given, are compared. Thus Kalmia latifolice has a broader leaf than Kalmia angustifolia; but it has a uarrow leaf compaled with any species of trillium.

Rewo'te, remo'tus. Sce relative proportion.

RE'NI-FORM. See kidney-form.

REPAND', rcpan'dus. Having small sinuses, separated by teeth in the form of segments of small circles. Spread.

Re'pens. See creeping.

Replacement. Applied to a crys. tal when its angles or edges are wanting, and are supplied by a plane face or other augles.

Rep'tans. See creepiug and run. ner.

Res'tans. See permanent. Remaining.

Resupina'tus. Upside down.

Retic'vlats. Netted. Having veins crossing each other like net-work.

RE'T1-FORA. Net-form, net-like.

Retractile. When the head, or other organ, may be drawn back, as the drawing in of the lead of a tortoise.

ReT'Roflex, retroflex'us. Bending in various directions.

Retrofrac'tus. See refracted. Bent suddenly back.

Retror'so-denta'tus. See runcinate. Teeth bent back.

Retu'se, retu'sus. Ending in a sinus generally hollowed out but very little. See emarginate. REver'SED. Bent back towards the base.

Rev'oluts, revolu'tus, Rolled outwards. A term in foliation; 
applied to leaves whose oppo. site margins are rolled outwards and continued rolling, till the two rolls meet on the back of the midrib and parallel to it. It is the ieverse of involute.

lihizosper'ma. Fruit on the root of some terns.

Rnом'віс, rhom'beus. See deltoid. Diamond-form.

Rhomboi'deus. Diamond-spot like. Riв. A nerve-like support to a leaf.

RIB'BED. When the midrib sends off lateral ribs nearly strait to the margin. It is sumetimes put for ncrved.

lic'tus. See gape. Opening of the mouth.

MrG'In, rig'idus. Stiff, inflexible, or not pliable; or if attempted to be bent, will ratlier break.

Runo'se, rimo'sus. Chinked, abounding in cracks, as the outer surface of the pitcli-pine tree.

ling. The band around the capsules of ferns, which is elastic. See exanulatus.

It is also the thin membrane attached to the stem of a fungus. When young it is attached to the pileus. It is erect when the upper edge is not fastened -inverse, when the lower edge is not fastened-sessile, when it is attached by one side onlymobile, when it may be pusied up and down-persistenl, when it is as durable as the pileusfugacious, when it disappears at the opening of the fungus.

RiN'gexr, rin'gens. See labiate. Gristing.

Ri'sing. See assurgens.

Root. The descending part of a vegetable, which enters the earth, or other substance, in search of nourishment for the plant. Roots are annual, bienzial, or perennial. See ages. 'They are branching, fibrous, grecping, spindle-form, tuber- ous, hulbons, or granulated. See each term in its place.

RooT'ING. Bending or extending to the earth and striking root.

ROoT'LEAF. See radical.

Root'let. A fibre of a root.

Ro'ridus. Humid. Appearing as if covered with dew.

Rosa'ceous. A corol formed of loutulish spreading petals, with. out claws or witli extremely short ones.

Ros'cus. Rose-coloured.

Ros'TEL, rostel'lum That pointed? part, which tends downwards at the first germination of the seed. See corcle.

Rostra'lus. See beaked. Having a bill.

Ro'tATE, rota'tus. See wheelform.

Rotuzidus. Found. without angles.

Rovgr. Covered with dots, which are harsh to the touch, but not apparent to the naked eye. See rugged.

Round. See rotundus. Circu. lar.

Ru'bra. Red.

Rubigino'sus. Rust-coloured.

Rudera'lis. Growing among rub. bish about buildings, \&c.

Ru'fous. Reddish yellow.

RUG'GED. Covered with invisible dots, which are harsh to the touch. See rough.

RUGo'se. Wrinkled. Veins more contracted than the disk, so that the intermediate pyrenchyma rises up between them.

Run'cinate. Pinnatifi, with the divisions pointing backwards; as the dandelion.

RUN'NER. A shoot producing roots aud leaves at the end only, and from that place giving rise to an. other plant.

Rupes'tris. Growing naturally among rocks.

Rutilus. Shining, bright, glossy. 
尺.

SA'BRE-FORM. See acinaciform.

Sac'cate. Furnistred with a little bag. Bag.like.

SaG'ITtate, sagilla'lus. See arroiv-form.

Silifrrous. vialt bearing. Applied to a secunditry lock ils which salt sprums are found.

Sal'sus. Salt-tasted

SAL'ver-Form A mouopetalous corol with a fiat preading limb proceeding from the top of a tube.

SAM'ARA. A ivinged pericarp not opening by valves; as the maple.

Sin'arond. Resemhling a samara, or winged capsule.

Sap. The watery fluid contained in the tubes, and cellules if ve. getables, which furnishes the ineans, or is itself, the suppori of their growth and life, and their preservation irom decay. 'That part of the sap which suipplies materiais fur the grouth, roliage and frusuticiation, evidently ascends by way of the camb. Sce vanib. But that, which fills the interstices among the woody fibres, and serves to preserve them from decay, is probably raised by capullary at. traction. Freezung and thrwing in some way or uiher suspends for a day or two the elfect of capillary attractiois. It then descends by its natural gravily; at which season only can the sap we obtained from the sugar maple. That it descends is evident from the fact, that no sap is obtained from below the incision, except a few drops at the first moment after it is made That the sap descends from the woody fibres and not from the camb appears from inspection. That this sap serves only topreserve the rood appears from the raphl decay of the wood in the sugar maple directly ahove the incision to the whole extent of the bule; wlule the incismun produces but little effrct below it. And the herbage of the tree with the outer layers it woul con. tinue as fourishing after the tree lias lieell clrained of its sap. 11. uually for lialf a century, as its neighbours, which have nevel lost any sap. It may be observ. ed further; that saj cau never be drawu froin the same vessels above the incision where it has been drawn in any preceding year; unless a new incision be made several feet above the old one. Nor even the 1 , if the preceding draining had leen very cousiderable, or, in other words, if the sugal-making seasom had been very favourable, and the incision larce.

Sapin'dus. Having some kind of taste.

Sap'or Having a relish, pleasant, any taste. Culour simetimes indicatestlıp taste. White berries are generally sweet; red, sour; blue, sweet and sour; black, insipid and poisonous-IVilldenow. But certainly our spicy wintergreen (gaultheria,) par. tridge-berry (mitcletlia,) and whortleberries (vaccinium ) are exceptious to IVilldenow's rules.

Sarmento'se, sarmento'sus. A innning shoot, which strikes root at the knots or joints only. Generally applied to shrubs. Sec runner.

SAU'CER-FORM. Shaped like a common tea-saucer.

Scab'er, SCA'BROUS. See rough. Scabrities. Roughness.

Scal'Lopped. See repand.

ScalLy. Covered more or less with scaly appendages, as fern roots; or consisting of substances, in some measure resembling 
conrse fish-scales; as the scates of lily roots.

Scan'ders. See climbing.

Scansoral. Having feet formed for climbing - two toes forward and two lusckward.

ScaPE, scap'us. See peduncle. Flower stem from the root.

Scapulars The feathers, which descend down each side of the back.

SCA'RIOUS, scario'sus, Dry and membranous, generally transparent.

SCAT'TERED Standing without any regular order; that is, neither opposite, alternate, nor in any defiuabl series.

Scuismatop'terides. Dehiscent ferns Ous of the new orders of ferns It is adopted by Pursh, Torrey, \&c. O-munda, lyg:diuin and schizæa are placed liere

Sc'10x. Shoots proceeding laterally trom the roots or bulb of a root.

Sco'red. See sulcate. Furrowed.

SCRAG. Back of a bird's neck. SCrobic'deate, servbicula'lus. Deep round pits on tire recepta. cle gives it this name.

Scutel'le. See shields

Sculel'lalus. See saucer-form.

SCYM'ITAR FuRm. See acillaciform. Cutlass form.

Scyph'ifer, Scyph'us. Cuphearing. See cyathilorm.

Sec'rion. The genera of some orders and the species of some genera are divided into sections. Sections judiciously constructcd greatly facilitate the investi gation of plauts. But they otien mislead; and must he somefimes disregarded, and the whote order read over; especially under tho ${ }^{*}$ - orders which are made up of natural families. See the orders siloquosi in the clas. lelradynamia of Linneus's sys. iem.
Secun'dus. Turned to one side. Ont-sided, one-ranked

SEED. The matured part of fructification, destined for the reproduction of the species. It contains the rudiment of a new plant and is analogous to the egg of animals. It cousists of the corcle, cotyleduns, tegument and hilum; which see.

SEE D-BUD. See germen.

SEE'D-cost. See aril. Shelly corering ol seeds.

SEL'J-LEAVES. The cotyledons expranded into leaves.

SEE'D-LOBES. See cotyledons. r leshy part of seeds.

SEe'D-vessezs. See pericarp. coverug of seeds.

SEG'MENT. l'he jarts into which a caly $x$, corol, leaf, ac. is divided oi cut.

SEGREGIA'TA polygamia. Sec 1. 18.

St'jugus. Six-paired.

s'e'men. The sred.

Serriamplexic un'lis. Half clasping the stem.

SEMICULUM'NAR. See semiterete. laperiug lualf-cylinder.

semecylindru'ceus Half-cylindric. In torm of a round ruler split tenytluwise.

semifies'culus, srmi-rzo'ret. See ligulate rirap-like

semi-tiferui, Half-ìferior-Whes tise calyx grows on the side of the ger'a, so that it is neither superiur nor uferior.

seminallis. See seed-leaves. Cotyl-ilonous leaves.

Scminatio. The sowing of seeds. reminif'era Bearing the seed. SEMIOKBIC'ULAR, semior icula'lus.

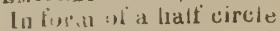
Semiquin quef'zdus. Half 5-cleft. scmisagulla'lus Half-arrowform. Tuat is, one side wanting; as in the ricia pusilla.

crisc $x^{\prime}$ fidus. Half 6 -cleft.

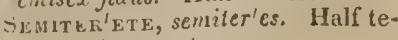
rete Seeterete.

Semper'vircns, Learing through 
the winter and retaining the leaves.

Se'nus. Six-fold. Growing in sises.

Sen'silis, sEs'stTrve. Moving on being touched. Seo irritability.

Scnsim. Gradually, loy little and little. Applied to a form, Se. which arises gradually from some other form.

SeNTIENT PRINCIPLe. The knowing principle. That faculty by which animals are enabled to take notice of external objucts.

SEP'ALS The divisions of a calyx, or corol Raf.

Septif'erous. Supporting partitions.

Seria'tus. In a row, or in rows.

Seric'cus. Silky. Euvered with soft cluse-pressed lairs.

Scroli'nus. Coming to maturity late in the seasun. Applied to wiliows, and to some other plants, it implies, that the time of flowering is after the leafing.

Ser'pentine Mar'gin. Seerepand. Waving edges.

SER'RATE, serra'lus. (Serra, a saw.) Having sliarp notclues, kppearing as if eut, about the edge or margin, pointing towards the apex.

SER'RULATE, serrula'lus. When a serrate leaf has the teeth serrate again. It is also applied to any serratures, which are very fine.

sesquiai'ter. When a large fertile fluret is accompanied by a small sbortive one.

SEs'sile. Sitting down. When a leaf, flower, seed-down, pileus of a fungus, receptacle of a liclien, \&ic. are destitute of a petiole, peduncle, stipe, \&cc.

Sella. A bristle.

Seta'ceus. Bristle-form. Applied to rutennae.

Selig'erous. Bearing bristles.

Scto'sus, seto'se. Bristly. Having the surface set with bristles, c: stiff strait hairs.
Sexangula'ris. Six-angled.

Sex'fidus. Six-cleft.

Sexiflorus. Six-flowered.

Sex'jugus. Six-paired.

Seracula'ris. six-celled.

Sex'us, Sex. When Linneus first adopted the stamens and pistils as the organs of classitication, he addressed his urguments to physicians, who were conversait with animal nuatony. He therefor'e took advantage of the analogy betwern auimals and vegetables in the reproduction of their kind, in order to illustrate his theory. He called the stamens males, and the pistils females, ecc. But uothing can be unore ridiculous and disgusting than to keep up these references at this day.

S'exval'vus. Six-valved.

Snart. See style. A nane for the central organ of a flower.

Snatigy See hirsute. Rough tangled hair

Suarr. Tapering to a point. Acute differs from sliarp, as it may apply to the tip of a leaf, which becornes broad immediately back of the point.

SnEATr. The piolungation of a leaf down the stem, which it encluses; as in most culmiferous plants.

SuE'ATnED. Having a sheath.

SHateds, sculel'le. That kind of receptacle of lichens, which is open, orbicular, saucer-like. 'The under side and borkler are of the substance and colour of the frond. The disk is of a different colour and substance from the border and frond, containing the seeds in extremely minute vertical cells. The shields are thick and tumid, when they are sessile ; and membrauous, when stalked or elevated. Very rarcly they are perforuted in the centre.-Smith.

Suı'sing. See lucidus.

Snoot. Eacli tree and slirub sends forth annually a large shoot in 
the spring, cailed the spring shoot; and from the end of that a smaller one about the $24 \mathrm{th}$ of June, called St. John's shoot. There is always the appearance of a joirst where the latter spriugs out, very perceptible after the whole shoot is matured.

SurIV'eltivg. See withering. Snrur. A vegetable with a woody stem. It is generally put for that kind of woody plant, whose stem diviles into branches near the ground, without being elevated by a bole, like trees. See tree and suffrutex.

Surub'by. Líaving woody stems or branches.

Sic'cus. Dry, neither humid nor succulent.

SICK'LE-FORar. A very much curved keel.

SiDEs. Applied to shells means the right and left, when riesed from the tront, (opening side) or back.

Sız'ıcL, silic'ula. A little silique, ivhose lengtl and breadth are nearly equal.

SILICULO'SA. See p. 16.

Sillique, sil'iqua. See p. 5.

Sithleur-Form. Sliaped like a silique without its essential character.

SILIQUO'S.A. See p. 17.

SIL'KY. See sericeus.

SIM'Ple, sim'plex. Undivided. Single, opposed to compound, aggregate, or branched.

S'implicis'simus. Very simple.

Sin'GLE. Only one. Also opposed to full-flowered.

Sinistror'sum. Twining from right to left, that is, contrary to the apparent motion of the sun; as the pole-bean.

SiN'Uatr, sinula'tus. (Sinus, a bay.) Having rounded incisions. The margin hollowed out, resombling a bay; as the white oak leaf.

SIN'UATE-SER'RATE. Having ser- ratures hollowed out; as the chestnut.

Sı'Nus. A roundish incision into the edge of a leat or other organ. Sipunculus. A canal, or successiou of perforations, connecting the chambers of some univalve spiral shells.

Sit'ting Ser sessile.

Siltus. Situntion; as opposite, alteruate, \&ic.

Slezr. See glabrous.

SleEP of plasts. The effect of niglit upon the exterual appearance of some plants; as the leaves of pens c!nsing over the very young tlowers.

SLeN'DER. See ti nuis.

Si.opes. The edges wi an oblique bivalve shell. Anterior slope, is the edge in which the ligament is situated. Posterior slope, is the edge in which the beaks of the shell turn forward; being the edge opposite to that in which the ligament is situated.

Smarag'dinus. Grass-green.

Smootir. Sumetimes put for glabrous, but not symonymous with it. For glabrous means sleek or slippery; whereas smooth may be applied to fine cliamois leather.

Sobolif'erous. Buaring shoots. Sol'id, sol'idus. Of an uniform substance, not naturally partible; as the turuip. See coated and scaly.

Sul'itakr, solita'rins. Standing alone, or very distant from other's of the same kind.

Solu'tus. Disengaged. Not adliate, or growing together.

Somewar. Used as a diminutive; inplying in some degree, not fully. Prisident Smith translates sub, by somewhat, when combined with an adjective ; as subtrifidus, somewbat three-cleft.

Somnus planta'rum. Sec sleep of plants. 
Sor'dide al'bicans. Dirts white. Sórus and S'rre'dia. See fruit dots. Clusters of the fruit of ferus.

Spadi'ceus. Chestnut brown

Srádix. An elongated receptacle proceeding from a spathe, or resembling such in texture and appearance.

SPAN'Gles, patel'lula. Op,en and orbicular, like shields, but sessile, and not formed of any part of the crust, from ivhuci they differ in colour, being most usually l,lack The sceds are lodg. ed beneath the membrane that covers their disk, as in the former, and the disk is surroundrod by a proper bolder. Their seeds are observed to be naked in the cellular substance of the disk, not encloscd in cares. Dis' sometimes coiscavc or flat, if. tener convcx, and evcu glubost willout any apparent bordcr when in an advanced state.

Spatha'meus. A span high, or a span long.

SPA'THE. That kind of calyx, which first encloses the flower and after it expand is left at a distance below it. As daffodil, onion, Indian turuip.

SPA'THE-roru. Resembling a spathe.

SPat'olate, spatula'tus, or spa. thula'tus. Roundish and dininislaing into a long, narrow, lin. ear base.

SPE'C1Es. The lowest division of vegetables. There have been, about forty-five thousand species describcd. In North Ainerica about four thonsand pheno gamous species have been described ; of these about twentyfive hundred are found to the north and northeast of Virginia. De Lamark and De Candolle make 4866 species of plants in Erance, including thi crypto. gamia. In the yeur 182.2. in the third edition of the Aletrat of
Botany for the states north of Virginia, 3065 species wrire des. cribed. ('ommon cultivated exotics and soine cryptogamulas plants are included in this $111 \mathrm{~m}$ ber. About oue thousand phenogimous species love bicu exaınined by Professor Ives in a wilci state, wilnn five miles of Yule College. Very lew ulaces of the sainc extent wi!l alford more than eight liundred, and few less lhan six hundred, in the Nortlicin States. Phelps gives a catalogue of thirtren liundred and forty phenogamous species as a complete list of all the Brilish plauts

SPECIF'IC CHAR'ACTER. Seo diagnosis and descriptions.

SPECIF'ic NaMe III common usc we apply this to wliat Linueus called the trivial name. The specific name be calls all those several descriptive word:, w hich express the essential difference, or diagnosis.

The raye for changing specific names lias become a grcat uuisance to the science. IRichard proposes the establishment of a literary tribunal, having authority to fix the names in every department of science for the whole glute ; in order to chesk the grosvth of this child of vanity and ignorance.

SPHA'CELATE. Withering, becoming blackened.

SPHAGNo'sE. Wet, mossy, strampy.

SPHERULE. Small globules of nearly a regular spherical form. Spitculus. See spikelet.

SPIKE, spi'ca. Having florets arranged along the sides of a general elongated peduncle or re. eeptacle, without partial pedun. cles or with extremely shori ones. As a wheat-head, or mul. lein

Spíkelet, spi'cula. One of the subdivisions of a spike. 
SPIX'DRE-FORIS. See fusifurm.

SPINE, spi'na See thorn.

SPINES'CENT, spines'ccrs. Becomiing thorny.

SPINo'se, spino'sus. Thorny.

SPI'RAL, spirallis. Twisted like a screw.

Spire Is applied to all the whorls of a univalve shell, which extend upwards above the first whorl, called the body or belly of the shell

SPIT-PoIN'TED Barton substitutes this for cuspidate.

Spilh'ama Short span. See measures

Spongio'sus. Spongy.

Spor'a. The sceds of lichens.

Sporan'yinum. A name given to the pericarp by Hedwig.

Sporangid'ium. Willderıoiv's name for the columella of mosses. Sce columella.

SPOT'TED. Having spots differing in colour from the principal nart

Spread'ing Sce patens.

SPUn. An elongated process from the liase, or from near the base of the caly $x$ or corol or nectary, souse what resembling a horn or cock's spur. As the Larkspur, Orchis and Nasturtion.

SPUR'red. Having a spur, or processfrom the base.

STUR'RED-RY'E, Or SPUR'RED GII'IN. An enlarged, elongated seed, projecting out of a glume, of a black or violet colour, brittle texture, somewhat spur-torm. It is that morbid sivelling of the sced, called Ergot by the French. The black or dark coloured kind is called the Malignant ergol. "Large doses of which cause bead-ache and febrile symptoms Under proper regulations it may be considered a valuable addition to the present stock of medicinal agents. The dose usually administered is from ten grains to half a drachır, in decoction."
Bigelow: The pale violet kiud, called simple ergot, is harmless and inactive.-Willdenow.

Graiı growing in low moist ground, or new land is most sub. ject to it. Also spring grain more thas winter grain: and rye morc than wheat, barlcy or oats.

When crops are so much in. fccted with it as greatly to in. jure them, the loos may be in $a$ great meacure made up by col. lecting the ergot, and selling it to druggists. It sloould be thor. oughly winnowed out of the grain, as it is said to be very injurious in bread. The ergot may then be collected from the chaff.

SQuAMIForm. Of the form of scabs or scales.

Squanulo'se, squamo'sus, or squamatus Ste scaly.

SqUARRo'se, squarro'sus. Ragged. When the points of scal s, \&c. bend outwards, so as to make $n$ ragged appearance. It is also used for scurfy, or when cover. ed with a bran-like scurf.

Stacnyop'terides. Spiked ferns. One of the new order of Ferns. It is adopted by Pursh and oth. ers. Lycopodium, Botry chium, Bernhardia and Ophioglossum are placed here.

Stark. See stem.

STtámen. See p. 3.

TTAM INATE Having stamens orily, without a pistil. See p. 6.

Slamin'eus. Having no corol, the stamens serving in its stead.Ray.

Staminif'erous. Sce staminate. Bearing stamens only.

Stan'dard. Sce banner. Upper petal of pea-flowers.

StEL'LATE, stolla'lus. Spreading out in a radiate manner. Leaves are stellate, when three or more surround the stem in a whort. Flowers and the volva of a fun. gus are stellate, when the petals or segments spread out, so as co 
resemble the valgar representation of a star.

STEAr. The main base or supporter of the fructification and herbage. It is either Tige, Culm, Scape. Peduncle, Petiole, Frond or Stipe; which see.

SiTEM-CLAS'PIYG. See clasping.

STE $\mathbf{M}^{\prime}$-LEAF. Inserted on the stem.

See cauline.

Stes'Less. Having no stem.

STEmata. Small globules, often lucid, resembling eyes. They are generally three in number on the top of the head.

STER'ILE, ster'ilis. Barren flower. Staminate flower.

STrFF. See rigid.

S'rig'ma. The top of the pistil. It is generally moist when in full perfection, for the better reception of the pollen.

Sitings, slim'uli. Hair-like processes, which excite itching punctures; as on the Nettle. They are generally hollow with a sack at the base, cortaining an acrid liquor. By pushing against their points, the sacks are compressed, and thrust out the liquid.

STIPE, stipes. The lower part of the midrib of a fern; the stem of a fungus; or the stem of the down on the seeds of Dandelion; the stem of a germ elevating it above the receptacle ; or any other stem-like organ, not otlierwise particularly nained.

STIP'ITATE, STíPED, stipila'lus. Having a stipe.

Stip'vee, stip'ula. A leafet or scale at or near the base of a petiole, which in some respect differs from the leaves.

STIP'ULAR, slipula'ris. Formed of, or connected with, stipules.

SrIP'ULED, stipula'lus, or slipula'. ccous. Having stipules.

Stol'o See sucker.

Slolonif'erus. Putting forth suck. ers, or shoots.

Strad'Dling. See divaricatc.
Straigitt, or strait. In nearly a right line.

Stra'rrisir. A little curving, but not sufficiently to take the ap. pellation of curved.

Stramin'eus. Straw-coloured ; straw-like.

Strap'-fory. See ligulate.

Stratum. A layer. It is applied in a general or partial sense. $A$ general stratum of rock, or of detritus, inay include several partial strata. These partial strata, or sub-strata, should be called layers, to avoid circumlo. cution and confusion.

Stra'lum prolig'erum. The seed. bearing dists of the receptacle of lichens.

Striae. Marks or lines on minerals, on elytra of insects, \&c.

STRI'ATE, STRE'AKED, slria'lus. Marked or grooved with slende: lines.

Stricllus. Both stiff and strait, or perfectly strait. See erect.

Striclis'simus. Very stiff and strait. Strigo'se, slrigo'sus. Armed with small, close, rigid bristles, which are thickest below. - ivilde. now.

Strobila'ceus. In for'm rosembling a strobile.

Stro'bile, slrob'ilus An ament with woody scales; as the fruit of pine.

Strobilifor'mis. See strobilaceus. Stroma. The layer or covering of some fungi.

StYLE, slyl'us (Slulos, a column.) That part of a pistil, which is between the germ and stigmn. It is often wanting; as in the Tulip.

Sty'loid. Resembling a style.

Suatvis. Siweet, agreeable.

Sub. Used in combination as a diminutive. See somewhat.

SUbero'se, subero'sus. Corky.

SuBMER'sed, submer'sus. Growing under water.

Subler'rancus. Growing and flowering under ground. This may 
be applied to the shoots of the Polygala rubella.

Siub'tus. Beneath.

SuB'Ulate, subula'lus. See awlform.

Subuniflo'rus Generally one flowered, but sometimes more.

Succulen'lus, suc'colent. Juicy, abounding in juice. It is also applied to a pulpy leaf, whether juicy or not.

Suc'cus. See sap.

Suc'ker. A shoot from the root by which the plant may be propagated.

SuFfru'ticose, suffrrutex. An under-shrub. A plant whose branches annually die, but the lower part of the stem is woody and remains, as the Spirea alba, white steeple-bush ; also Sage. Suffrutico'sis. Undershrubby. Sul'cate, sulca'lus. Furrowed. Marked with deep lines.

Sulphur'cus. Sulphur-coloured.

Sup'crans. Exceeding in height. Soprrad'iliary. Above the axil. Superdecompound'. See supradecompositus.

Supkrfic'irs. See pagina. S'UPER'FLU.9 polyga'miu. See p. 18.

Super'ne. Upwards, towards the top.

SUPE'rior, sup'erus. A calyx or corol is superior when it proceeds from the upper part of the germ. See germ.

Supi'nus. Face upwards. See resupinatus. Upside down.

Supporrt. See fulcrum.

S'upra-axilla ris. See suprafoliaceus

Supradecomposilus. More than decompound ; which see. When a petiole is divided and the di. visions dirided at least once more, and the last divisions have leafets.

Śsprafolia'ceus. Inserted above the asit, or base, of the leaf.
S'ur'culus. A little branch or twis. Applied to the stem or shoot which bears the leaves of mosses.

Su'ture, sutu'ra. A seam-likc appearance at the meeting of two parts ; as the valves of ycapod, the parts of a skull, \&c.

Sivim'

SwORD'-Form. See ensiform.

Syluati'cus. Growing in woods.

Sylves'tris. Altogether wild ;

growing in wild woods.

SrnaEnesious. (Sun, together; genesis, springing up.) Anthers growing up together in an united tubular set. It is applied to all those plants, whose flowers are compound, having the anthers in cach floret with more or less of their edges adnate; so that thc whole (which are always 5) form a tube. See p. 14.

SYno' nys synon'yma. Different names for the same plant.

Srnop'sis. A condensed systematic view of a subject, or science.

SYs'TEM, syste'ma. An arrangement of natural bodies according to assumed characters ; for the purpose of aiding the mind and memory in acquiring and retaining a knowledge of them, systems have been proposed in abundance. And we are still infested with system-maker's and reformers, which are among the greatest evils incident to Natural Science. Any man of ordinary talents may makc a tolerable system in half a day; that is, sixty systems per month. But why not adhere to that which is universally known and cstablished? There may be improvements in the Linnean system. But let them be adopted with caution, and on the authority of the oldest and most expe. rienced botanists. 
'T.

Tenia'nus. Ribbon-form. Tapeforın.

'Tall. A filiform process terminating a seed, \&c. As the Virgin's bower.

TAll-covints. A clump of feathers above the tails of birds, adjoining the bases.

TAIL-FEATIERs. Th-large feathers of the tals of bilds-generally either $10,18,21,1) \mathrm{r} 24$-but 12 is the most common number. Tule'a. Sucker.

'ItA'PERING. See attenuatus.

'PAR'GETs, pel'la That kind of receptacle of lichens which is flat, close-pressed, arid altached to the frond by its whole undersirle, as if glucd; sometimes attached to the bark of the frond It is broad, kidney-form, or oblong, rarely irrcurular ; covered with a thin coloured disk, with no border except occasionally a very minute accessory ouc, which seems to circumsc:ibe it. In an early stage it is concave, and coicealed by a thin gelatinous fugacious membrane, or veil. - Suith.

Tar'get-Furu. See peltate.

Tarsus. The ancle aud foot of an insect, cxcepting the hook or claw at the extremity.

TAste. See sapor.

Tectrics. Wing coverts The lungest teathers of a bird's wing, next above the quills. Minor iectrics are sometimcs found abuve the larger.

Tec cus. Covered.

Tyetif of mosses. The outer linge of the peristomium is gen. erally in $4,8,16,32$, or 64 divisons. which are called teeth. See peristomium.

Teglens. Covering.

'TEG'UMENT. The skin or bark of seeds; as appears very distinct on a boiled pea or bean.
Temperaters. The degree of heat and cold to which auy place is suliject. This is not linaited to degrees of laritudc ; as high mounlaius in l'eumsyl. vania protuce mauy plants, most natural abuut Hudson's bay. In cold regions whitc aud blue petals principally prevail ii) warm regions red and other bright stroug colours.

In the spring seasou white petals prcdominate; towards autunin the yellow are most prevalent.- Willdenow.

TEN'DRIL. That kind of appendage, which is filiform ant reaches out to grasp bodics to climb by. As the climbers of grapes and peas.

Tcnel'lus. Tender, delicate and fragile.

Tr.ntacuza. The arms, or feclers, of insects, and of other oniinals.

Tenuifol'ius. Slender-Icaved.

Ten'uis. Thin and slender.

Ter'es. See terete Tauering cylinder.

TeR'ete. Round, columnar, and tapering from the base to the wher end

Teretiusculus. Somewhat tercte.

Tergem'inus, Tergem'inate Thrice: parred. The petiol is forkect. thesc branches forked, and the last branches with paircd leafets.

TER.us Technical terms should be defined in a dictionary of each science and urt. But ivoris used in thcir common accepta. tiou, whether Greek, Latiı, English, French, oc. should not be defined III such a dictionary, however frequently applied il sucls science or art.

Ter'minal, termina'lis. Procced. ing from or occupying the cnd of a stcm, branch, style, \&c.

Termanal'tions. In cxpressing re. semblances it would greatly 
lengthen descriptions to introduce words drawing full-lengtlı comparisous. As a leaf resem. bling the form of an arrow. To avoid this, terminations united to the substantive word by a hyphen have been used; as arrow-shape, or arrow-form. I prefer the termination form, inaking the whole a compound adjective 11,um. There are cases where like bec imes a convenient termination; as petallike stigma in the lris. Here form or shaped would be inadequate; as its resemblance consists rather in texture and general appearance, than in shape.

Jer'nate. Three-fold. In threes. This term is also applied to compound leaves, where 3 leafets procced from the end of one petiole; as in the Strawberry. See bitcruate and triternate.

Tcrru'ncus. Appertaining to the eartls.

T'er'reus. Earth-coloured.

'Tes'selate, lesscla'tus. Chequered.

IESTACEous. Shelly, crusty. Applied to insects it generally means light brick-colour, ap. proaching the colour of tanned sheepskin.

Tcter. IJaving a disagreeable smell.

TETRADYNAMLA. (Tessares, four; dunamis, power.) See p. 13.

Tetradys'anous. Belonging to the class tetradynamia, or varying into it.

Tetrago'nus. Four-cornered.

TETRAGYN'IA. Tessarcs, four ; gune, female.) See p. 16.

TETRAN'DRIA. (Tessares, four ; aner, male.) See p. 12.

Tetran'd rous. Belonging to, or varying into, the class tctrandria.

Tetrapel'alous. Four-petalled. Tetraphyl'lus. Calys with four leafets.
Tetrapleryg'ia. See wings.

Tetrasper'mus. IHaving 4 seeds to a fower

Tctrre'ira. A 4-sided pod.

Thatam'ia. See hollows.

Thallus. The frond of a lichen, heilly the bed or general receptacle whereon the proper receptacles are reposed, or in which they are imbedded.

The'cr. The capsules of mosses.

The'cce. The frond, ur whole herbage of licheris. The cases or cells containing the seeds in the disk of scutella and some other receptacles of lichens

Trokn, or spine. A sharp process from the woody part of a plant. It is an indurated imperfect bud, which, when the plant grows in a rich soil, changes to a branch. Pears bear thorns in a poor soil, which disappear in richer.-Willdenow.

THREad'-Form. See filiform.

THREE' FOLD See ternate.

THRice-PIN'Nate See tripinnate.

Thrice-pinnat ifid. See tripin. natifid.

Throat Seefaux Jaws.

Thyrsioitdes. Flowers disposed in the form of a nosegay.

THYRSE, thyr'sus. See panicle.

Tige. See caulis. The most common stem.

Tinclo'rius. Plants suitable for dying or pigments.

TonerTo'se, lomento'sus. Covered with fine downy or cottony substance matted together. See lanate.

TONG'UE-FORM. See linguiform.

TOOTH'ED. See dentate.

Tooth'Letrin. See denticulate.

TOP'-FORM. See turbinate.

Torn See lacerated

'ToRo'se, toro'sus. Protuberant. Raised in bunches or vein-like protuberances or ridges. Knobs on a toad.

Tor'sio. See intorsion. Tarning inwards.

Tor'tilis. See coiled. 
TORULO'se, torulo'sus. With swell. ing ridgez; like the muskmelon.

Trac'hea. The air.ressels of Givew. They are spiral channels supposed hy Grew to be designed in receiving and distribut. ing air in vegetables.

Trailling. See procumbent. Lying or banging down.

Translu'cent. Transinitting light faintly

Trans'verse, trans'versus. Crosswise. It is applied to a partition wben it meets the valves of a pericarp in any otber part than at the sutures.

Trapezifor'mis. Having four unequal sides.

'Eres, (arbor.) A large woody plant. The word large is very indefinite; but the distinction between tree and shrub is very difficult to express. Perhaps large and small, interpreted according to the rules relating to parts under Relative proportions, will serve to distinguish trees and shrubs as well as an elabo. rate definition. These terms are not used in specific descriptions. See slirub and suffrutex.

TRIA N'DRIA. (Tris, thrice; aner, male.) See p. 12.

'TRIAN'Drous. Belonging to, or varying into, the class triandria.

'TrIAN'GULAR, triangula'ris. Having three angles or corners. It is applied to a leaf with 3 points or corners.

'TRIBEs, tri'bus. See gentes and cotyledon.

T-IARAC'TEATE. Having three bracts.

Tricce. See buttons. Button-form. Irichol'omus. Three-forked. See forked.

Tricoc'cus. A 3-seeded capsulo; or rather 3-grained. It is applied to capsules, which appear as if three, of one cell and one seed eash, were grown together.
Tricuspida'tus. Three pointed. Sec cuspidate.

Triuen'tate. Three-touthed.

Trid'uus. Enduring 3 days.

Trifa'rius. Facing 3 ways.

Trif'idus. Three-cleft. See cleft.

Triflor'rus. Three-flowered.

Trifolia'tus. Three-leaved.

Triglo'chis. Three-barbed. See barb.

Trigo'nus. Three-cornered. See triangular.

TRIGY $\mathcal{N}^{\prime} I A$. (Tris, thrice; gune, female.) See p. 16.

Trij'ugus. Three-paired. Threeyoked.

Triloba'ceous, $t r i^{\prime} l o b u s$ Threclobed. See lobed.

Triloc'ular, trilocula'ris. Threecelled.

Trinervis. Three-nerved. Sec nerved.

Tri'nus. Leaves in threes.

Triparti'tus. Deeply divided into three parts.

Tripet'alus. Tliree-petalled.

Triphyl'lus. Three leafets to a ca Iyx.

TrIPIN'Nate, tripinnatus. Having the petiole pinnated with other petioles; and this second range of petioles supporting a third range with leafets.

TRIPINNAT'IFID, tripinnatif'idus. A pinnatifid leaf, with the divi. sions pinnatifid, and those latter divisions pinnatifid again. Sec piunatifid and bipinnatifid.

Triplinervis. See trinervis. Threenerved.

Triply-Com'pound. See Supradecompositus.

Trip'teris. Three-winged.

Trique'trrous, trique'ter. Three. sided.

Trisper'mo. Three-seeded.

Tris'tis, Dull-coloured, melan. choly.

TriteR'Nate, triterna'tus. When a petiole is divided into three branches; and the branches again divided, each in three parts; and on each of the last 
divisions thiree leafets. Sec biternate.

Trival'vis. A pericarp with three valves.

Trivascula'ris. Having three cupform cells.

T'miv'ial Name, trivia'lia no'mina. The naine of a species, not including the descriptive terms. President Smith says, trivial name is now superfuous; as specific name is no longer used for the descriptive terms. See specific name.

Trun'cate, trunca'tus. The end appearing as if cut off. Termiuating in a strait edge, either perpendicularly or obliquely transverse.

'Trusk, trun'cus. The bole of a tree. See bole. It is also ap. plied to the stem of plants not woody; and sometimes to the caudex of a root.

TUBe. The lower hollow cylinder of a monopetalous corol.

Tu'Bercess, tuber'cula. That kind of receptacle of lichens, which is spherical or slightly conic, nearly closed, crustaceous, black; more or less immersed in the surface of the crustaceous frond,-which it elevates ; or sometimes it is exposed, being mcrely sessile. Each contains a ball, or mass, of connected seeds, destitute of cells, enve. loped in a common membrane. The whole mass of seeds is at length discharged together by an orifice at the top of the tubercle. We often find these tu. bercles after the seeds are discharged.

TUBER'CULATE, tuber'cula. See tubercles. This word is sometimes applied to rough points on leaves, \&c.

Tu'BERous, tubero'sus. Roots, which are thick and fleshy, but not of any regularly globular form. They are knobbed, as potatoe; oral, as orchis and some anemones ; Abrupt, as the birdfoot voilet; Fascicled, as the as. paragus.

Tu'BULAR, tubula'tus. Having a tube, or being in the form of a tube.

Tu'Bulous, Tubulo'se, tubulo'sus. That corol of a compound flower, which forms a whole tube, not a ligulatc floret. It is also applied to a perianth, if the whole or the lower part is a hollow cylinder.

TUFT'ED. See fascicle. In a bunch or bundle.

Tu'Nicate. See coated. Covered as with a garment.

TuR'Binate, turbina'tus. Topform. A cone with the point downwards.

TUR'GID, tur'gidus. Thickened, swollen, but not inflated.

Túrion, tu'rio. See gemmation. Budding.

Twin. Tivo connected or grow. ing together.

TIVI'NING. Ascendiug spirally, See dextrorsum and sinistrorsum.

Twis'Ted. See coiled.

TWO-RANK'ED, or TWO-ROW'ED. See distichus.

\section{V.}

Vagilna. Sheath. That prolon. gation of a leaf, which forms a cylinder around the stem. See sheath.

Vagi'nans. Sheathing.

Vagina'tus. Sheathed.

Valva'tus. Resembling the valves of a glume.

VALVE, val'va. The several pieces of a pericarp, which separate naturally on ripening, are called valves. Also the leaves, ol chaffs, of a glume. Each piece is called a valve. This name is sometimes applied to the scales, which close the tube in some corols. 


\section{$V E R$}

Tat'veret, val'rula. L the valve. Variega'tus Virioustu coloured VArI'rity, varititas. The changes produced among plants of the sume specites lis accidental canses; is liy soil, situation, culture, climate, \&c. P'rese changes revpect mayniture. fullness of flowers, crisping of leaves, co. lour, taste, and sme.t. If the same kiud of plant can possibly be produced $f \cdots "$ the serd of othre kind;, threse are but varjpties of the same species. All apples are bnt virieties of the same species; because if the seed of a sour apple be planted. they will produce trees bcaring sour, sweet, tart, red, green, large and small apples promiccuously. But the quince is a different species; because it cannot possibly be produced from apple seeds

$I^{\prime} a^{\prime} s a$, vessels. The sain-versels of vegetables have formed the subject of much inquiry and discussion. The best summary of the various thenries may be found in Smith's Elements See sap and camb. By cutting very thin transverse segments of a. quatic pla its, and holding $t: 1 \cdot m$ to the light, considerable prac tical knowledge may be obtain. ed on this subject

VAUL'TED. Arched over like the roof of the mouth; as the upper lip of some labiate cor ils

VEG'ETABLE. An arganized substance, whose procreative organs decay before the individual dies. As in the pea; the sta mens and pistils decay before the rest of the plant It is dirided into the fructification, root and herbaze. See natural history.

VRG'ETABLE KING'DOJ. This is the nume Limueus gives to all the subjects of the science of botany. See natural hiatory. TEG'ETARLE SUB'STAI si. The ele- mentary principles of vegetahles are carbon. hydrogen, and oxygen ; sıme contai i nitrogen.

Thr proximale pri riples are very comulicate l, and belong to the drmartm.nt of chemistry. Vril. Seecalyptra, aud volva. Iellus Fleecy, or " $\mathrm{l}$ ece This term is alsn applied to that kind of clouls which fluat swiftly abon' the sky, wit'tout any strait side, an' l resemble an open fleecc of ivool $S$ is clintis.

VeIN'ED, VENo'se, ven'suls. A leaf with the ribs or tendioness fibres vario:isty branched.

VEvT. Aperture for the discharge of hoth feces and nrine.

Ventricles. The large cavities of the lieart. HII animals of the classes mommalia and aves have two venticles $t$ th the heart -ismnlubia aud piaces but une.

VENTRico'se, venlriro'sus. Swell. ing out as if blown up will wind. Or rather bellied ont. See inlated.

Ventrierlosus a little ventricose. VERBES, All avirtobral animals, prcepting insects. - Linneue.

Verna'lis. Coming forth early in the spring.

VERNA'TION, vernalio. See foliatinn.

Verru'ca. Varionsly formed pro. tuberances, solid and nsually smonth, on the crust of some lirhens. Sometimes the recepacles grow on thein.

VFrRUCO'SE, veriucosils IVarty. Haviug little warty knob-like substances on the surface.

VER'SATILE, rersa'tilis. Lving horizontallv and moving freely on a point. Particularly applied to anthers lying on the point of the filaments.

Ver'tex. The summit.

VER'TICAL, vertica'lis. Standing or hanging up and down at righi angles with the horizon; or pa. rallel to the stem. 
VERTEBRAL ANIMALS. One of the four grand divisions of animals, characterised by liaving back bones. Avertebral animals have no back bones, as uysters, lobsters, \&cc.

I'cricilla'tus. See whorled.

Vesic'ular, vesicula'ris. Containing, or consisting of, a cellular substance.

VEs'sels. Seevasa.

Vexil'lum. See banner of peaHowers.

VIBRIssie. Smellers. Hairs of a peculiar kind, generally very stiffy, growing on or near the nostrils.

Vigi'lie planta'rum. The determinedhours of the day, when certain plants expand and shut their iliwers. See sleep.

VILLO'SE, villo'sus. Having a superticial covering of long soft whitish hairs. The calyptra of some mosses consists wbolly of a mat of hairs.

Vil'lus. Fine soft hairs.

Vi'men. A withe, A twig which is slender and flexible.

Viola'ccous. Violet coloured.

Vircs'cens. Inclining to green.

VIR'GATE, virga'tus. IVand-like. Slender rod.

Vir'idis. Green.

Virgul'tum. Small twig.

Viro'sus. Nauseous disgusting sinell.

VIs'cid, vis'cidus. Covered superficially witl a tenacious juice.

Viscid'ity, visco'sitas. Clamminess. Possessing an adhesive quality

Vitcl'inus. Yellow with a tinge of red.

Vitcl'lus. A thin substance in the seeds of some plants, closely connected with the embryo, but never rising out of the ground switl it in germination. It is never in plants with genuine asconding cotyledons; and per- haps it may serve to perform the fuuctions of cotyledons. It is between the albumen and embryo, when albumen is present. It composes the bulk of the seeds of mosses and ferns.Smith.

Vil'reus. Glassy, colourless. See hyaline.

Vivip'arous. Producing its offspring alive, either by bulbs instead of seeds, or by seeds germinating on the plant. It is applied to animals produced alive, not from the egg.

Uligino'sus. Growing in damp places.

Ul'na. Arm's length.

Un'BEL, umbel'la. That kind of iuflorescence, where several flower-stems diverge from one place, like the braces of an um. brella; bearing florets on their. extremities. If these flowerstems are subdivided, a partial umbel is formed.

UMBELLIF'EROUS. Bearing UMbels ; as carrot, dill, fennel.

Ua'Bellet, umbcl'lullu. A partial or lesser umbel

Umbi'licus. A naval. Applied to shells, it means the pertoration in the direction of the spire, as in the nerita, \&c.

UMBIL'ıcatre, umbilica'lus. Navelled. Having a kind of central roundish liolluw or protuberance; as on the end of an apple, or of a pompion.

Uimbona'tus. See bossed.

Umbrimus. Umber colour. Snuftbrown. A brown shade.

Unangula'tus. One-angled.

UNARM'ED. Having no thorns no ${ }^{\circ}$ prickles.

Uncia'lis. As long as the thumbnail.

UN'crsate, uncina'tus. Hooked at the end. See hamus.

Unctuo'sus. Greasy, unctuous.

UN'DULATE, undula'lus or unda'tus. Vavy. Rising and falling, o: 
cxtending and receding in waves.

UN'DFrsniob. See suffrutex.

UNDIV1'DED. See indivisus.

UNE'QUAL. The parts not corresponding in size, form and duration.

UNGUIC'ULATE, unguicula'tus. petal with a claw.

Un'guis. A claw, which see.

UN'GULATE, ungula'tus. In the form of a horse's lioof; as the common touch-ivood, (boleteus igniarius.)

Unicapsula'ris. Having one capsule to each flower.

U'nicus. Single. Only one.

Uniflo'rus. One-flowered.

Unifor'mis. All parts alike, or corresponding.

Unilabia'tus. One-lipped.

UNILAT'ERAL, unilatera'lis. See one-sided.

Uniloculn'ris. One-celled.

UNINER'vial. OHe-nerved.

I'nisex'us. Either 'staminate or pistillate, not perfect.

Unival'vis. One-valved.

Univascula'ris. Having one cupform cell.

UNIVER'SAL, universa'lis. See partial, to which it is applied.

FoL'va. The ring or wrapper of some fungous plants, which contracts in size as the plant grows older; as the mushroom. WVilldenow calls that the volva only, which encloses the fungus in the young state, and remains close upon the ground ever aftcr. The ring around the stem above, he calls annulus. See ring.

Volu'bilis. See twining.

UPRI'GHT. See elect.

URCEOLA'TE, urccolatus. Bellying out like a pitcher, and not contracting much at top.

$\gamma^{\prime \prime}$ rens. Stinging, armed with stings.

URN'-Foris. Swelling in the middle and contracting at the top; as the calyx of the rose.

ifoprgiaL. Several long feathers above, on eacli side of the tail differing in form from the otll. ers.

Ustila'go. Smut in grain.

U'TRICLEs. The little bag-like reservoirs for sap, air, sec.

Utric'ulus. A little bladder.

Utrin que acu'tus. Sharpcning at botb ends.

- glab'er villo'sus, \&c. sleek, downy, dc. both sides.

\section{- IV.}

WAND-LiKE. See virgatus.

IVatrles. Peidant fleshy appen. dages under the clin of some swine and other animals.

WA $_{A}^{\prime}$ VED, or $\mathrm{WA}^{\prime} \mathrm{V} r$. See undulate.

WEDG'E-FORM. Obovate witl straitish sides.

WuEel'Forir. A monopetalous corol with a spreading border, and an extremely sliort tube.

IWHORL'ED. Surroundiug the stcm in numbers at intervals; as the leaves of bedstraw, and the flowers of motherwort. It is applied to the spiral convolutions of uni. valve shells.

Wings. The two side petals in a papilionaccous corol.

It is also applied to the mem. branes affixed to seeds or pericarps. Monopterygia, 1-winged. Dipterygia, 2-winged. Triptcrygia, 3 winged. Tetrapterysia, 4-winged. Pentapterygia, 5wingcd. Polypterygia, many. winged.

VItre. See Vimen. A flesible wand.

WhITH'ERING. Having a shrivelled and decaying appesrance. though not actually in a state of decay; as the flowers of elm, (ulmus.)

WooD. The most solid part of trunks and roots of trees and shrubs. It is also applied to the part of herbaceous plants be tween the bark and pit!.. 
Wood'x. Not herbaceous.

IVooL'LY. See lanate.

WRINR'LED. See rugose.

Wri'tued. See coiled. Twisted.

$$
\text { Z. }
$$

Zigzag. Sce flexuose.
Zoozocr. The science of animals.

Zoophytes. Animal-plants. The radiated animals, which resemble plants in many respects. Such as the sea fan; \&c.

\section{CORRECTIONS,}

To be made with the Pen.

Page 20-3d line from bottom, " 1 " " should be 16 .

25-5th line from top, "four" should be three.

31-18th line from bottom, the words, SECTION I. Flowers aps. talous, should be struck out, and printed with the pen in the space between where they now stand and the line above.

33-18th line from bottom, the words, Section II. Flowers monopetalous, should be treated as above directed.

39-7th line from the bottom, the words, Section III. Flower: polypetalous, should be treated as above directed.

48-23d line from the bottom, the words, SEcrion IV. Dielinious or anomalous, should be treated as above directed.

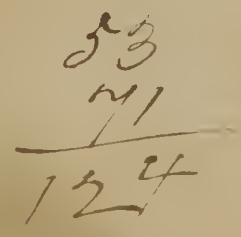


1

.

4

1

,

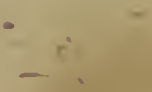




$$
\begin{aligned}
& M+d_{1} H i-t .
\end{aligned}
$$

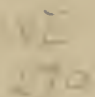

$$
\begin{aligned}
& \text { Bulle } \\
& 1821 \\
& \text { (1) }
\end{aligned}
$$


